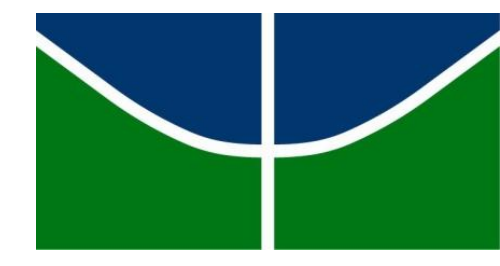

Universidade de Brasília - UnB Instituto de Ciências Biológicas - IB

Programa de Pós-Graduação em Biologia Microbiana - PPGBM

PERFIL GENÉTICO E TOXICOLÓGICO DE CIANOBACTÉRIAS NO LAGO PARANOÁ, BRASÍLIA/DF

Mayara Oliveira Sousa

Brasília - DF 
MAYARA OLIVEIRA SOUSA

\section{PERFIL GENÉTICO E TOXICOLÓGICO DE CIANOBACTÉRIAS NO LAGO}

PARANOÁ, BRASÍLIA/DF

Dissertação apresentada ao Programa de PósGraduação em Biologia Microbiana da Universidade de Brasília, como requisito à obtenção do título de Mestra em Biologia Microbiana.

Orientadora: Professora Lenora Nunes Ludolf Gomes 


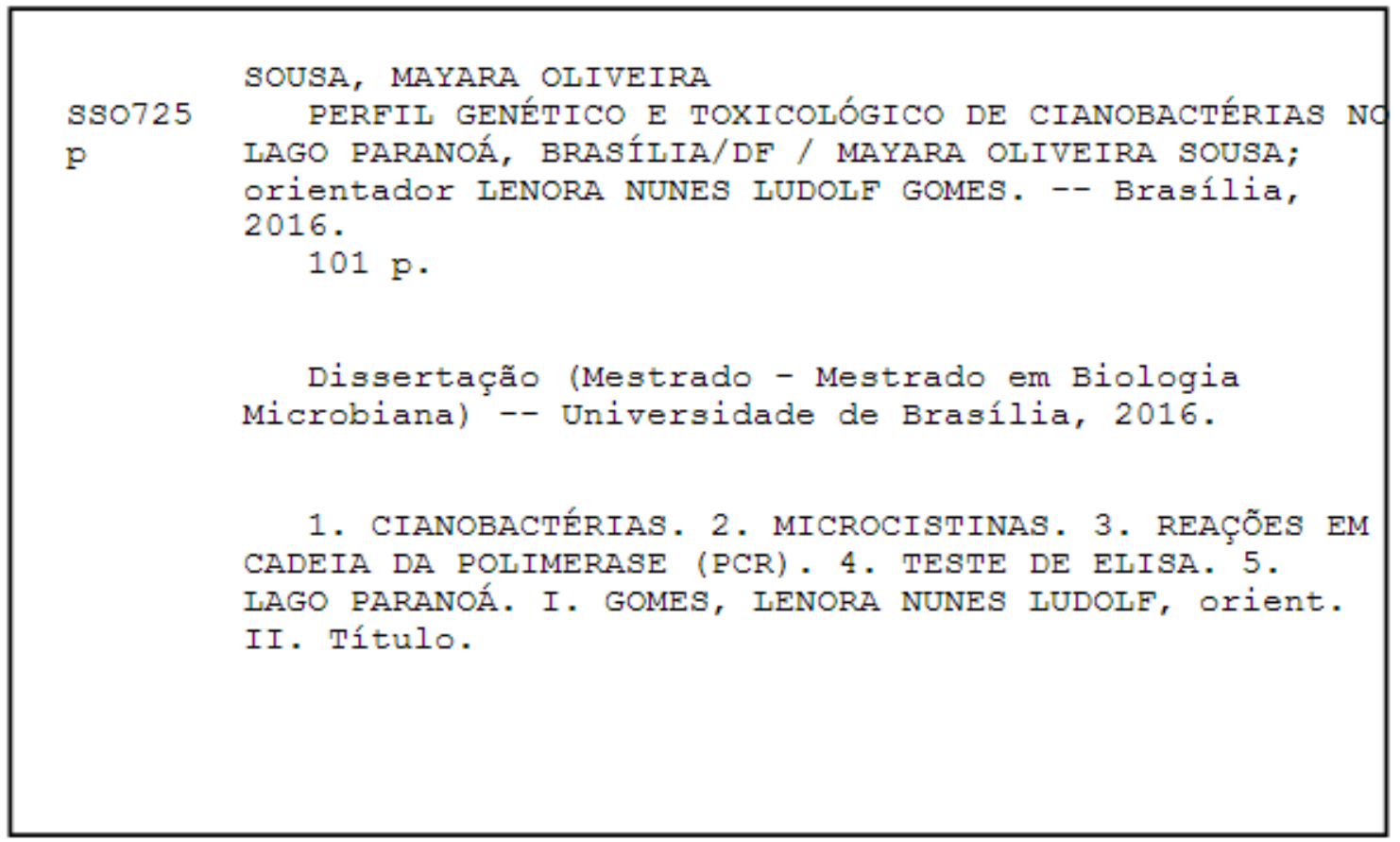




\section{PERFIL GENÉTICO E TOXICOLÓGICO DE CIANOBACTÉRIAS NO LAGO PARANOÁ, BRASÍLIA/DF}

Dissertação apresentada ao Programa de PósGraduação em Biologia Microbiana da Universidade de Brasília, como requisito à obtenção do título de Mestra em Biologia Microbiana.

Defendida e aprovada em: 10 de Outubro de 2016

Banca examinadora formada pelos professores:

Professora Lenora Nunes Ludolf Gomes (PhD) - orientadora

Universidade de Brasília - Faculdade de Tecnologia/Departamento de Engenharia Civil e Ambiental

Professor Helson Mario Martins do Vale (Doutor) - membro interno

Universidade de Brasília - Instituto de Ciências Biológicas/Departamento de Fitopatologia

Professor Ricardo Tezini Minoti (PhD) - membro externo

Universidade de Brasília - Faculdade de Tecnologia/Departamento de Engenharia Civil e

Ambiental

Professora Cynthia Maria Kyaw (Doutora) - suplente

Universidade de Brasília - Instituto de Ciências Biológicas/Departamento de Biologia Celular 
Ao meu querido Deus por me permitir tamanha conquista. Aos meus pais Evandro e Fátima, por todo amor e incentivo. Ao meu esposo Evannildo e minha filhinha amada Mannara, por toda dedicação, paciência e por me ensinarem o real significado da palavra amor. Aos meus irmãos Júnior, Maylson e Mayrton por acreditarem na minha vitória. Às minhas avós, em especial à vó Espedita por todo seu cuidado e afeto. 


\section{AGRADECIMENTOS}

À minha orientadora profa. Lenora N. L. Gomes, pelo acolhimento e pelos saberes compartilhados com tanta dedicação.

Ao prof. Tatsuya Nagata, por sua colaboração no desenvolvimento do trabalho.

Ao prof. Helson M. M. do Vale, por sua colaboração, apoio e pelos ensinamentos compartilhados durante o curso de mestrado, que foram importantes para o desenvolvimento da pesquisa.

Aos professores Ricardo H. Krüger e Cynthia M. Kyaw, pelo apoio durante o desenvolvimento da pesquisa.

Às professoras Eliane F. Noronha, Maria Lucrecia G. Ramos, Janice L. de Marco, Yovanka Ginoris e Ariuska Amorim, pelos conhecimentos compartilhados nas disciplinas cursadas.

Ao professor Ricardo T. Minoti, pelas valiosas contribuições que nortearam o desenvolvimento do trabalho.

Às minhas companheiras acadêmicas Rafaella e Catharine, por todo apoio e disponibilidade durante essa jornada, pelas palavras de incentivo e força em momentos de dificuldades.

À Carla Vizzotto, por sua tão valiosa contribuição para o desenvolvimento da pesquisa, pelas discussões sobre nossa metodologia e pelo carinho nos momentos bons e difíceis dessa jornada.

À Luciana, Sara e Marcilene por tornarem os dias de trabalho no laboratório mais agradáveis.

À Regina pelos conselhos, ensinamentos e conversas no laboratório de Ecologia.

À Luciana Medeiros e Aline, por sempre atenderem prontamente nossas demandas na secretaria do curso de mestrado.

Ao Instituto Federal do Maranhão - Campus Codó - pelo incentivo e valorização da formação docente.

À Unidade Regional de Educação do Estado do Maranhão pelo incentivo à formação de professores. 
À toda equipe de trabalho do Centro de Ensino René Bayma, por acreditar no meu potencial e por estar sempre disponível para me auxiliar na resolução de questões burocráticas referentes ao meu afastamento para capacitação.

À toda minha família materna e paterna, por todo incentivo e amor.

Às minhas amigas Carol, Thaís e Lôrena, que mesmo distantes sempre têm uma palavra de amor, um conselho e um acalanto em momentos de dificuldade.

Às minhas companheiras da Biologia, em especial à querida Rakel Sena, que se tornou uma grande amiga e me acolheu com tanto amor nos primeiros meses de moradia em Brasília. 
"O papel dos infinitamente pequenos na natureza é infinitamente grande." (Louis Pasteur)

“Tudo quanto te vier à mão para fazer, faze-o conforme as tuas forças.” (Eclesiastes 9: 10) 


\section{RESUMO}

A proposta do presente trabalho foi entender a dinâmica da ocorrência de cianobactérias no lago Paranoá, pelo uso de ferramentas moleculares desenvolvidas para a identificação de cianobactérias potencialmente produtoras de toxinas, uma vez que, o Lago é um reservatório urbano, que será utilizado como fonte de abastecimento público. Dessa forma, é necessário monitorar a presença das cianobactérias potencialmente tóxicas, a fim de avaliar a qualidade da água do Lago. Para isso, foram coletadas amostras de água no período de 2012 a 2014. As amostras foram usadas em ensaios de PCR, com o emprego de oligonucleotídeos do gene $16 \mathrm{~S}$ DNAr, do operon da ficocinina e dos genes de síntese das microcistinas $(m c y \mathrm{~B}$ e $m c y \mathrm{D})$. Alguns dos resultados positivos das reações de PCR foram sequenciados para a identificação das cianobactérias presentes na área de estudo, e a quantificação das microcistinas foi realizada por meio do teste de ELISA. Foi detectada a presença de cianobactérias (avaliação qualitativa), por meio das reações de PCR convencional, em 97\% das amostras de água avaliadas com os iniciadores do 16S DNAr. Os iniciadores referentes à porção da ficocianina $(\mathrm{PC} \beta \mathrm{F} / \mathrm{PC} \alpha \mathrm{R})$ amplificaram somente $13,8 \%$ das amostras avaliadas. Com relação aos oligonucleotídeos dos genes de síntese das microcistinas ( $m c y \mathrm{~B}$ e $m c y \mathrm{D})$, apenas um deles - mcyD - amplificou fragmento em uma única amostra. Isso provavelmente ocorreu devido à baixa concentração do DNA alvo no DNA genômico extraído do fitoplâncton e à presença de interferentes da PCR em amostras ambientais. É necessário o desenho de iniciadores específicos para as sequências de cianobactérias brasileiras. O resultado do sequenciamento revelou $100 \%$ de similaridade com a sequência de Radiocystis sp. JJ30-12. A presença de microcistinas foi constatada em todas as amostras avaliadas. Por fim, pode-se afirmar que as reações de PCR, utilizando iniciadores específicos relacionados com a síntese de cianotoxinas, como por exemplo, as microcistinas, podem ser úteis para a otimização das metodologias analíticas usadas para o monitoramento de reservatórios, e precisam de estudos mais aprofundados com o intuito de aprimorar os protocolos atualmente utilizados para a amplificação de fragmentos de interesse. Dessa forma, elas poderiam ser incluídas nas análises de rotina, em programas de monitoramento da qualidade da água, sendo úteis para identificação de cianobactérias.

Palavras-chave: Cianobactérias. Microcistinas. Reação em cadeia da polimerase (PCR). 


\begin{abstract}
The purpose of this work was to understand the dynamics of the occurence of cyanobacteria in lake Paranoa through of molecular tools developed for identifying of potentially cyanobacteria producing toxins, since the lake is an urban wealth that will be used as a source of public supply. Thus, it is necessary to monitor the presence of potentially toxic cyanobacteria, in order to evaluate the quality of the reservoir water. For this, water samples were collected in the period of 2012-2014. The samples were filtered and used in PCR assay, with the use of oligonucleotides $16 \mathrm{~S}$ rDNA gene, the ficocian operon and microcystins synthesis genes $(m c y \mathrm{~B}$ and $m c y \mathrm{D})$. Positive results of $\mathrm{PCR}$ reactions were sequenced to identifying the cyanobacteria present in the area of study and the quantification of microcystins was performed by ELISA kit. The cyanobacteria were detected (qualitative assessment) for conventional PCR reactions in $97 \%$ of water samples evaluated with the primers 16S rDNA. Primers related to phycocyanin (PC $\beta F / P C \alpha R)$ amplified only $13.8 \%$ of the samples. Regarding to oligonucleotide of gene synthesis of microcystins ( $m c y \mathrm{~B}$ and $m c y \mathrm{D})$ only one of them - mcyD - amplified fragment in a single sample. This was probably due to low concentration of template DNA within genomic DNA extracted from phytoplankton and the presence of interfering PCR in environmental samples. It is necessary to design specific primers for sequences of Brazilian cyanobacteria. The result of sequencing showed $100 \%$ similarity with the sequence of Radiocystis sp. JJ30-12. The presence of microcystins was found in all samples. Finally, we can affirm that the PCR reactions using specific primers related to cyanotoxins synthesis, for example, microcystins can be useful for optimization of analytical methods used for the monitoring of reservoirs, and it need more studies in order to improve the protocols currently used for the amplification of fragments of interest. Thus, they could be included in routine analyzes, monitoring programs of water quality, and useful for cyanobacteria identification.
\end{abstract}

Key Words: Cyanobacteria. Microcystins. Polymerase chain reaction (PCR). 


\section{LISTA DE ILUSTRAÇÕES}

Figura 3.1 - Estrutura química de cianotoxinas

Figura 3.2 - Organização do agrupamento de genes responsáveis pela biossíntese da microscitina

Figura 3.3 - Figura esquemática ilustrando os processos ambientais que influenciam a ocorrência de florações de cianobactérias .......................................................................... 31

Figura 3.4 - Representação do grupo de genes de biossíntese de cianotoxinas ........................ 37

Figura 3.5 - Representação esquemática do operon da ficocianina......................................... 37

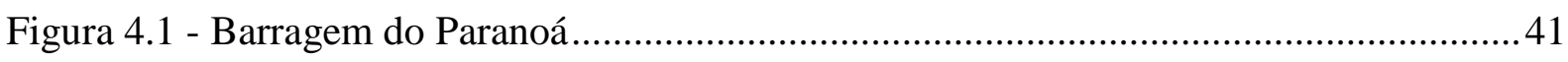

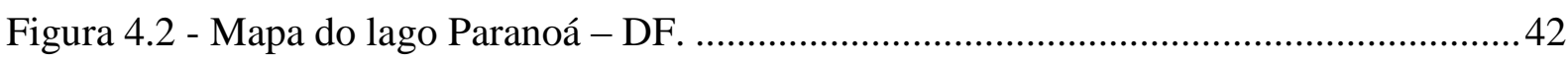

Figura 4.3 - Ponto de captação de água no lago Paranoá ........................................................ 44

Figura 4.4 - Localização dos pontos de coleta de amostras no lago Paranoá............................ 45

Figura 5.1 - Imagem do gel de agarose contendo o DNA genômico extraído de amostras coletadas em agosto de 2012 (parte superior do gel) e em janeiro de 2013 (parte inferior do

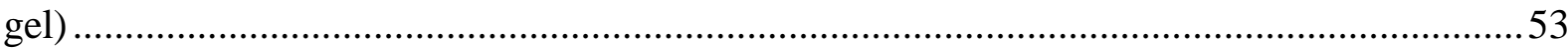

Figura 5.2 - - Comparação da PCR quantitativa em cels.mL $L^{-1}$ e a PCR convencional de amostras ambientais. PCR quantitativa à esquerda e PCR convencional a direita .................61

Figura 5.3 - Plano de monitoramento de cianobactéria usando a contagem celular e a PCR

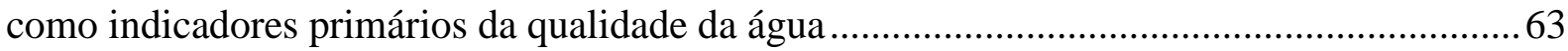




\section{LISTA DE QUADROS E TABELAS}

Quadro 3.1 - Exemplos de gêneros de cianobactérias potencialmente tóxicas encontradas em

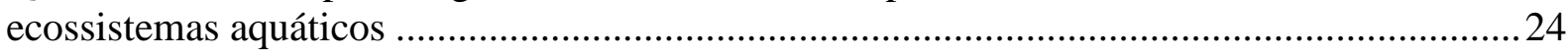

Quadro 3.2 - Localidades no Brasil onde cianobactérias foram identificadas ......................... 33

Quadro 3.3 - Métodos de detecção e/ou quantificação de cianotoxinas....................................39

Quadro 4.1 - Períodos e pontos selecionados para coleta das amostras ................................... 47

Quadro 4.2 - Pontos de referência das estações de coleta das amostras no lago Paranoá........ 47

Quadro 4.3 - Relação dos iniciadores oligonucleotídicos usados para a amplificação de porções distintas do genoma de cianobactérias: DNA 16S, operon da ficocianina, síntese de microcistinas

Quadro 5.1 - Resultados dos ensaios de PCR usando os iniciadores da porção do 16 S do DNAr, das porções cpcA e cpcB, incluindo o espaço intergênico (cpcBA-IGS), do operon da ficocianina e percentual de cianobactérias (indivíduo/mL) ..................................................51

Quadro 5.2 - Resultados das reações de PCR realizadas com os nucleotídeos iniciadores de

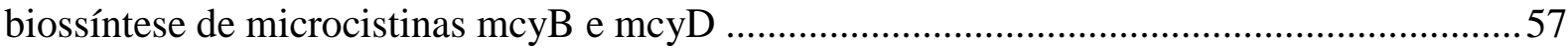

Quadro 5.3 - Resultado da quantificação de microcistinas em amostras de água coletadas no lago Paranoá

Tabela 4.1 - Caracterização do lago Paranoá

Tabela 5.1 - Valores médios de clorofila a $(\mu \mathrm{g} / \mathrm{L})$, densidade celular $(\mathrm{Cel} / \mathrm{L})$ e biomassa (mg/L) do lago Paranoá no período de 1999-2011 


\section{LISTA DE SIGLAS, ABREVIATURAS E SÍMBOLOS}

\begin{tabular}{|c|c|}
\hline$\%$ & Porcentagem \\
\hline$>$ & Maior que \\
\hline$\mu \mathrm{g} / \mathrm{L}$ & Micrograma por litro \\
\hline$\mu \mathrm{g} / \mathrm{mL}$ & Micrograma/mililitro \\
\hline$\mu \mathrm{L}$ & Microlitro \\
\hline$\mu \mathrm{m}$ & Micrômetro \\
\hline ADASA & Agência Reguladora de Águas, Energia e Saneamento do Distrito Federal \\
\hline ana & Anatoxina-a \\
\hline BLAST & Basic Local Aligment Search Tool \\
\hline CAESB & Companhia de Saneamento Ambiental do Distrito Federal \\
\hline $\mathrm{CO}_{2}$ & Dióxido de carbono \\
\hline CONAMA & Conselho Nacional de Meio Ambiente \\
\hline $\mathrm{Cpc}$ & Ficocianina \\
\hline Cyr & Cilindrospermopsina \\
\hline DF & Distrito Federal \\
\hline DNA & Ácido desoxirribonucleico \\
\hline dNTP & Desoxirribonucleotídeos \\
\hline EDTA & Etileno Diamino Tetra Acetato de Sódio Diidratado \\
\hline ELISA & Enzyme-Linked Immunosorbent Assay \\
\hline ETE & Estação de Tratamento de Esgoto \\
\hline EUA & Estados Unidos da América \\
\hline $\mathrm{Fe}$ & Ferro \\
\hline$G$ & Unidade gravitacional \\
\hline GDF & Governo do Distrito Federal \\
\hline HCL & Ácido clorídrico \\
\hline HPLC & High Performance Liquid Chromatography \\
\hline IB & Instituto de Biologia \\
\hline IGS & Espaço intergênico \\
\hline $\mathrm{Kb}$ & Quilobases \\
\hline $\mathrm{Km}$ & Quilômetro \\
\hline
\end{tabular}




\begin{tabular}{|c|c|}
\hline $\mathrm{Km}^{2}$ & Quilômetro quadrado \\
\hline KOAc & Acetato de potássio \\
\hline LAA & Laboratório de Análise de Águas \\
\hline $\mathrm{LC} / \mathrm{MS}$ & Liquid chromatography/mass spectrometry \\
\hline LPS & Lipopolissacarídeos \\
\hline M & Metro \\
\hline M & Molar \\
\hline $\mathrm{m}^{3}$ & Metro cúbico \\
\hline MALDI & Matrix Assisted Laser Desorption Ionisation \\
\hline Mcy & Microcistina \\
\hline $\mathrm{MgCl}_{2}$ & Cloreto de magnésio \\
\hline $\mathrm{mL}$ & Mililitro \\
\hline $\mathrm{Mm}$ & Milímetros \\
\hline $\mathrm{mM}$ & Milimolar \\
\hline MS & Ministério da Saúde \\
\hline $\mathrm{N}$ & Nitrogênio \\
\hline NCBI & National Center for Biotechnology Information \\
\hline nda & Nodularina \\
\hline $\mathrm{NH}_{4} \mathrm{OAc}$ & Acetato de amônio \\
\hline $\mathrm{N}^{\mathrm{o}}$ & Número \\
\hline NRPS & Non-Ribosomal Peptide Synthetase \\
\hline${ }^{\circ} \mathrm{C}$ & graus Celsius \\
\hline OMS & Organização Mundial de Saúde \\
\hline $\mathrm{P}$ & Fósforo \\
\hline $\mathrm{Pb}$ & Pares de bases \\
\hline PCR & Polymerase Chain Reaction \\
\hline $\mathrm{pH}$ & Potencial hidrogeniônico \\
\hline PKS & Polyketide Synthase \\
\hline Pmol & Picomol \\
\hline PPGMB & Programa de Pós-graduação em Biologia Microbiana \\
\hline PSP & Paralytic Shellfish Poisons \\
\hline RA & Região Administrativa \\
\hline DNAr & DNA ribossomal \\
\hline
\end{tabular}


SDS

Sxt

TBE

$\mathrm{UnB}$

UCB

WHO
Sodium Dodecyl Sulfate

Saxitoxina

Tris borato EDTA

Universidade de Brasília

Universidade Católica de Brasília

World Health Organization 


\section{SUMÁRIO}

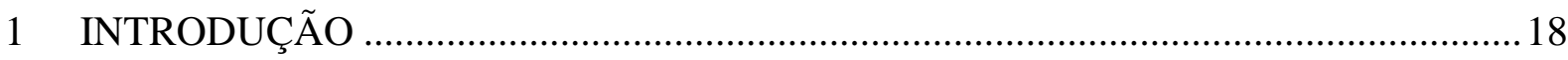

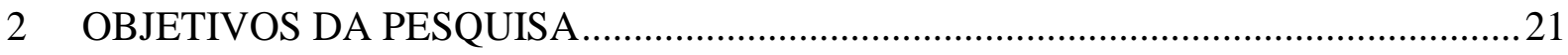

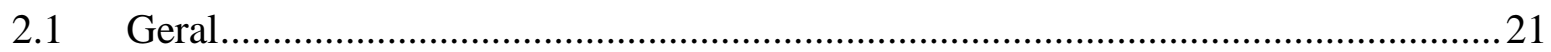

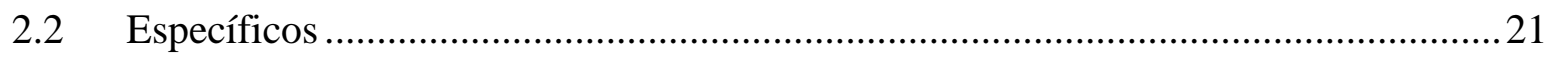

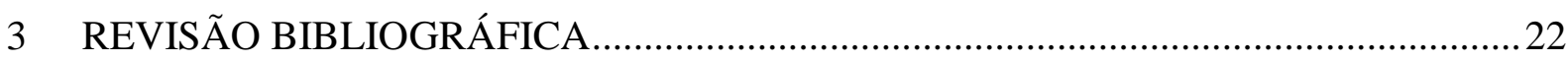

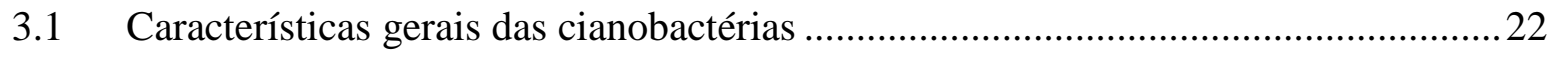

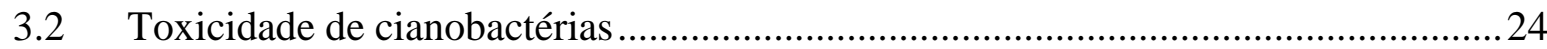

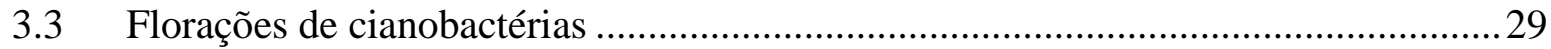

3.4 Ocorrência de florações de cianobactérias tóxicas ................................................. 32

3.4.1 Episódios de florações no mundo e no Brasil 32

3.5 Métodos analíticos utilizados para detecção de cianobactérias e cianotoxinas ..........34

3.5.1 Metodologias para identificação taxonômica e quantificação de cianobactérias34

3.5.2 O uso de marcadores moleculares via PCR para detecção de cianobactérias 35

3.5.3 Metodologias para detecção de toxinas 39

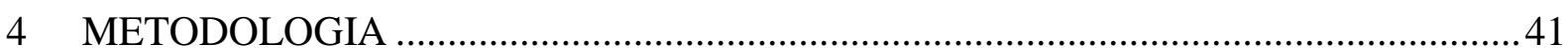

4.1 Descrição da área de estudo: lago Paranoá ............................................................ 41

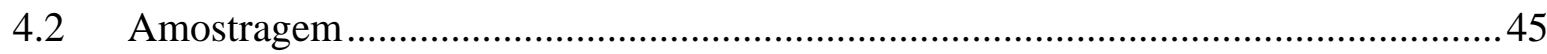

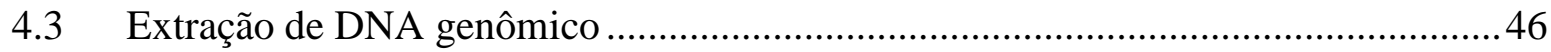

4.4 Amplificações usando PCR convencional ............................................................. 48

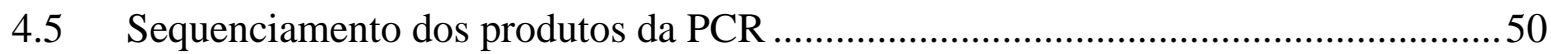

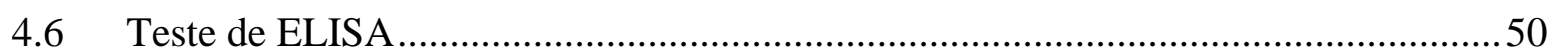

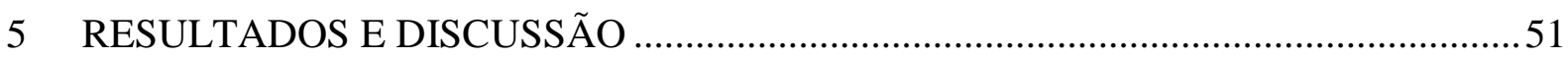

5.1 Perfil genético e investigação da toxicidade das cianobactérias...............................51

5.1.1 Caracterização molecular 51

5.1.2 Investigação do potencial de biossíntese de microcistinas 57

5.2 Discussão sobre a eficiência da PCR convencional no monitoramento de

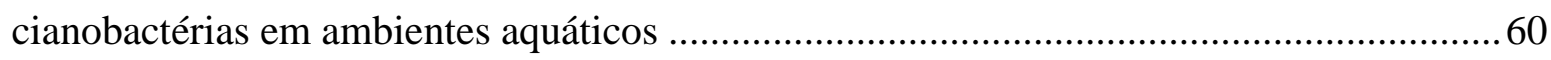

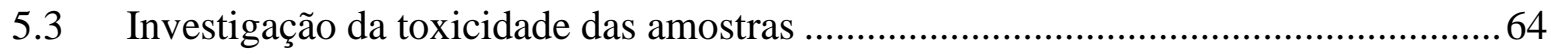

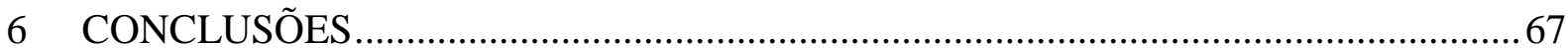

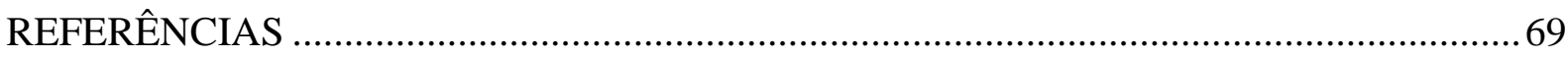

APÊNDICE A - IMAGENS DOS GÉIS DE AGAROSE (16S DNAr) ................................87

APÊNDICE B - IMAGENS DOS GÉIS DE AGAROSE (FICOCIANINA) .........................93 
APÊNDICE C - IMAGENS DOS GÉIS DE AGAROSE ( $m c y$ B e $m c y$ D)

.97 


\section{INTRODUÇÃO}

As cianobactérias são essenciais para os processos biogeoquímicos da Terra. Elas são consideradas responsáveis pela introdução do oxigênio elementar na atmosfera e são produtores primários importantes. A origem antiga e importância biogeoquímica das cianobactérias refletem na sua colonização em uma vasta gama de ambientes terrestres e aquáticos. Podem ser encontradas em ambientes frios e quentes, sendo essenciais na ciclagem de nutrientes, tais como, carbono e nitrogênio. Através de suas estratégias ecofisiológicas podem prosperar em habitats com pouca disponibilidade de nutrientes ou até mesmo em locais poluídos (CEBALLOS; AZEVEDO; BENDATE, 2006; DÍEZ; ININBERGS, 2014; WYNN-WILLIAMS, 2000).

A grande versatilidade fisiológica e ecológica das cianobactérias, permitindo-lhes adaptação a diferentes ambientes, relaciona-se, direta ou indiretamente, com a produção de diversos metabólitos secundários. Esses compostos produzidos pelas cianobactérias têm grande importância sanitária, uma vez que, podem ser tóxicos e causar riscos para a saúde humana. Os compostos tóxicos, chamados de cianotoxinas, podem ser produzidos por uma variedade de linhagens de cianobactérias, em ambientes aquáticos, causando, então, grande preocupação em relação à qualidade da água destinada ao consumo humano.

Diversos relatos de intoxicações provocadas por cianotoxinas, presentes em fontes de água, já foram documentados por todo o mundo, sendo responsáveis por graves problemas de saúde, inclusive a morte de animais domésticos e de seres humanos. Países, tais como, Austrália, China, Brasil, Inglaterra e Argentina relataram a presença de cianotoxinas na água (AL-TEBRINEH et al., 2012; DORR, et al. 2010; FALCONER et al., 1999; TURNER et al., 1990).

A confirmação do primeiro episódio de morte humana no mundo, associado às cianotoxinas, ocorreu no Nordeste do Brasil, no município de Caruaru em Pernambuco, em uma clínica de hemodiálise, após a utilização de água contaminada captada em ambiente impactado sem o adequado monitoramento do ambiente. A partir dessa constatação, os estudos relacionados à detecção, quantificação e mitigação da ocorrência de florações de cianobactérias em corpos d'água de usos múltiplos foram intensificados.

O crescimento populacional desordenado ao redor dos corpos d'água, o excesso de nutrientes, principalmente de nitrogênio e fósforo, e os processos de assoreamento são alguns dos fatores responsáveis pela alteração da comunidade fitoplanctônica em 
reservatórios. Esses eventos podem acelerar o processo de eutrofização nos ecossistemas aquáticos e, como parte desse processo, o desenvolvimento de florações de cianobactérias.

A metodologia tradicional de análise da dinâmica da comunidade do fitoplâncton inclui o uso de microscopia para a contagem e identificação de células por meio de caraterísticas morfológicas das cianobactérias. Essa abordagem é minuciosa e demorada, o que acaba dificultando a obtenção de dados rápidos e precisos, além de não permitir a detecção das cianotoxinas (LORENZI, 2004). Entre os métodos analíticos utiliza-se, para a identificação e quantificação de cianotoxinas em amostras de água, a cromatografia líquida de alta performance (HPLC), a espectrometria de massa (MS) e o teste de ELISA (do inglês Enzyme-Linked Immunosorbent Assay).

As metodologias baseadas na análise de biologia molecular, com foco nas sequências oligonucleotídicas de regiões específicas do DNA das cianobactérias, como as sequências do DNA ribossomal $16 \mathrm{~S}$, da região do espaço intergênico da ficocianina e as sequências de genes relacionados à produção das cianotoxinas - como $m c y A, m c y D$ e $m c y E-$ têm sido exploradas, com o intuito de desenvolver protocolos práticos de detecção de cianobactérias potencialmente tóxicas, em reservatórios de abastecimento de água (HA; HIDAKA; TSUNO, 2009; NEILAN et al., 1995; NEILAN et al., 1997; RANTALA et al., 2008; SEVILLA et al., 2010).

A aplicação de técnicas moleculares pode auxiliar na rápida identificação das espécies de cianobactérias produtoras de toxinas e proporcionar maior rapidez aos sistemas de alerta e controle de qualidade de água de mananciais de abastecimento humano; maior assertividade e segurança aos sistemas de tratamento de água, para diminuir os riscos à saúde pública, devido à exposição às cianotoxinas.

Portanto, a padronização e a aplicação de testes moleculares, capazes de detectar a presença de espécies de cianobactérias potencialmente produtoras de toxinas, podem tornar-se métodos importantes para o monitoramento da qualidade da água, minimizando os riscos da presença de cianotoxinas em mananciais para abastecimento de água.

O acelerado crescimento populacional do Distrito Federal, associado às mudanças nos ciclos climáticos e à escassez hídrica de 2016, tem aumentado a demanda de água para abastecimento público. Devido a isso, o lago Paranoá será utilizado pela Companhia de Saneamento Ambiental do Distrito Federal (CAESB) como manancial para abastecimento de água. Estudos realizados pela CAESB, no que diz respeito à disponibilidade de água do lago 
Paranoá, afirmam que este manancial tem capacidade de fornecer uma vazão de $2,8 \mathrm{~m}^{3} / \mathrm{s}$ de água, para fins de abastecimento público do Distrito Federal (CAESB, 2005).

Contudo, por ser um manancial urbano, seu uso como fonte de abastecimento público traz a preocupação quanto à presença das cianobactérias potencialmente tóxicas caso não haja manutenção da qualidade da água do reservatório.

A proposta do presente trabalho foi entender a dinâmica da ocorrência de cianobactérias no lago Paranoá, pelo uso de métodos moleculares desenvolvidos para a identificação de cianobactérias potencialmente produtoras de toxinas. A aplicação dessas metodologias nos ecossistemas aquáticos pode aprimorar o monitoramento das florações de cianobactérias e auxiliar na tomada de medidas de controle e prevenção da ocorrência dessas florações. Devido ao risco de contato e/ou consumo de água contaminada com cianotoxinas pela população, acredita-se que a utilização de metodologias rápidas e precisas na identificação de cianobactérias tóxicas possa trazer um avanço para a garantia da qualidade da água.

Os estudos de biologia molecular de cianobactérias possibilitam identificar os genes responsáveis pela regulação e produção das cianotoxinas. A detecção dessas sequências na comunidade de cianobactérias permite a identificação das linhagens produtoras de toxinas e pode ser uma ferramenta útil para avaliação do potencial tóxico das florações.

Com o exposto, entende-se que o estabelecimento de metodologia, com aplicação de técnicas moleculares, que permita a detecção e o monitoramento da ocorrência de cianobactérias potencialmente tóxicas em mananciais destinados ao abastecimento de água, apresenta relevância considerável. O desenvolvimento do trabalho visou avançar no conhecimento sobre a ocorrência das cianobactérias nos ambientes aquáticos, como também a oportunidade de melhor avaliar o risco potencial da presença de toxinas nesses ecossistemas, apresentando resultados rápidos e com maior confiabilidade. 


\section{OBJETIVOS DA PESQUISA}

\subsection{Geral}

- Investigar as populações de cianobactérias para identificação e determinação da dinâmica de ocorrência de ecotipos tóxicos no lago Paranoá, como parte do processo de utilização e aprimoramento do uso de metodologias moleculares na avaliação e monitoramento contínuo desse reservatório.

\subsection{Específicos}

1. Identificar a ocorrência de cianobactérias presentes no lago Paranoá entre 2012 e 2014 por meio de análises de biologia molecular;

2. Avaliar a eficácia da utilização de técnicas moleculares para avaliação e monitoramento contínuo da ocorrência de cianobactérias como suporte à avaliação da qualidade da água em reservatórios destinados ao abastecimento de água para consumo humano;

3. Caracterizar o potencial toxicológico de cianobactérias presentes nas amostras de água do lago Paranoá entre 2012 e 2014. 


\section{REVISÃO BIBLIOGRÁFICA}

O texto a seguir descreve os caracteres gerais das cianobactérias, suas adaptações, ocorrência, produção de metabólitos secundários, com ênfase para as cianotoxinas (descrição, estruturas químicas e mecanismos de ação). Trata ainda da ocorrência de florações de cianobactérias e faz um breve relato sobre os diferentes métodos analíticos utilizados para detecção e quantificação de cianobactérias e cianotoxinas em ambientes aquáticos.

\subsection{Características gerais das cianobactérias}

Cianobactérias ou cianofíceas são organismos procariontes, fotossintetizantes e produtores primários, que possuem características tanto de algas como de bactérias (SANT’ANNA et al., 2006). Podem formar colônias ou filamentos, ou ainda, viver como células isoladas. Suas populações podem ser visíveis, quando em elevada densidade, como colônias gelatinosas ou florações (blooms), embora sejam organismos microscópicos (CATHERINE et al., 2013; QUIBLIER et al., 2013).

As cianobactérias apresentam mecanismos eficientes para absorção de nutrientes e $\mathrm{CO}_{2}$. Algumas espécies podem fixar o nitrogênio (DÍEZ; ININBERGS, 2014), em células especializadas chamadas de heterocitos, por meio da enzima nitrogenase (KOMÁREK'; KOMÁRKOVÁ; KLING, 2003), o que lhes permite levar vantagem durante variações das condições ambientais em ambientes aquáticos (PAERL; PAUL, 2012).

Algumas cianobactérias possuem inclusões intracelulares importantes chamadas aerótopos que são vesículas de gás, presentes em muitas espécies planctônicas (ex. Microcystis spp.) (KOMÁREK, 2003). Cianobactérias que possuem aerótopos apresentam melhor estabilidade na coluna d'água, sendo esta uma vantagem competitiva sobre os demais grupos do fitoplâncton. Esses organismos podem então migrar verticalmente, aumentando sua capacidade de obtenção de luz e nutrientes em relação às espécies que não podem controlar a flutuabilidade na coluna d'água (MITROVIC; BOWLING; BUCKNEY, 2001; OREN, 2014; WHITTON; POTTS, 2000).

Algumas espécies de cianobactérias apresentam adaptações às condições anaeróbicas, crescimento em extremos de temperatura, salinidade e $\mathrm{pH}$, entre outros fatores que fazem com que essas, mesmo em condições desfavoráveis, possam sobreviver por longos períodos (OREN, 2014). Esses micro-organismos possuem diversos pigmentos responsáveis pela coloração e envolvidos no processo de fotossíntese. São eles: carotenóides, clorofilas e ficobiliproteínas (CHRISTAKI; BONOS; FLOROU-PANERI, 2015; TÓTH et al., 2015). 
Algumas espécies são cosmopolitas ocorrendo, principalmente, em regiões tropicais, por exemplo, Microcystis aeruginosa e Cylindrospermopsis raciborskii (CHORUS; BARTRAM, 1999; KOMÁREK; KOMÁRKOVÁ, 2002).

Outra importante característica das cianobactérias é a capacidade de produzir uma grande variedade de metabólitos secundários tais como: policetídeos, alcaloides e peptídeos. Algumas dessas substâncias possuem ação tóxica para animais e são denominadas cianotoxinas (ex.: microcistinas, cilindrospermopsinas e saxitoxinas). (CARMICHAEL, 1992; GADEMANN; PORTMANN, 2008; WELKER; DÖHREN, 2006).

A presença de cianotoxinas na água de consumo humano implica em sérios riscos à saúde pública, já que são hidrossolúveis e podem não serem eliminadas durante o processo de tratamento convencional (CARVALHO et al., 2013). A exposição crônica a baixas concentrações dessas toxinas pode, devido aos efeitos adversos potenciais (genotóxico, carcinogênico), a longo prazo, aumentar o risco para o desenvolvimento do câncer. Em regiões com florações de cianobactérias persistentes e atividades recreacionais intensivas, a exposição subcrônica pode causar efeitos adversos à saúde (ZEGURA; STRASER; FILIPIC, 2011).

A maioria desses metabólitos é sintetizada por complexos enzimáticos chamados peptídeo sintetase não ribossomal (NRPS - Nonribosomal peptide synthetase), policetídeo sintetase (PKS - polyketide synthases) e híbridos NRPS/PKS (MÉJEAN e PLOUX, 2013; MICALLEF et al., 2014), os quais catalisam a formação da estrutura química da toxina (SILVA, C. et al., 2012).

O complexo peptídeo sintetase não ribossomal (NRPS) é responsável pela montagem dos aminoácidos, levando à formação peptídica, e o policetídeo sintetase (PKS) é usado para interligar o acetato como bloco construtor principal na produção das toxinas. Uma vez que, as enzimas NRPS e PKS são capazes de aceitar uma vasta gama de diferentes substratos, um grande número de estruturas químicas diferentes pode ser obtido usando esses sistemas enzimáticos, o que resulta em uma diversidade de cianotoxinas atualmente conhecidas (VALÉRIO; CHAVES; TENREIRO, 2010).

Dentre as formas de contato com as cianotoxinas podemos destacar: a ingestão de água sem tratamento adequado para remoção das toxinas, o contato com água contaminada e o consumo de peixes e mariscos provenientes de ambientes aquáticos com ocorrência frequente de florações tóxicas de cianobactérias (MOTA; ROLLA, 2011). A rota de exposição às cianotoxinas inclui: inalação, exposição cutânea ou da mucosa nasal (FALCONER, 1999; NYBOM, 2013). 
Assim, o monitoramento das cianobactérias potencialmente produtoras de toxinas, nos mananciais de água para abastecimento público, é imprescindível para identificar os locais com risco potencial (BARTRAM et al., 1999; CARVALHO et al. 2013; MOSCHINICARLOS; NISHIMURA; POMPÊO, 2011; SANCHES et al., 2012;). A resolução CONAMA $\mathrm{n}^{\mathrm{o}}$ 357, de 17/03/2005 que dispõe sobre a classificação e as diretrizes ambientais para o enquadramento dos corpos de águas superficiais, e a portaria MS nº 2.914 de 12/12/2011, de potabilidade da água, estabelecem padrões para o monitoramento das cianobactérias (monitoradas via contagem em microscópio) e cianotoxinas, respectivamente.

\subsection{Toxicidade de cianobactérias}

Dentre as cianobactérias potencialmente tóxicas encontradas em ambientes aquáticos, pode-se destacar alguns gêneros, conforme apresentado no Quadro 3.1. Não há diferenças morfológicas entre linhagens de cianobactérias tóxicas e não tóxicas, dessa forma, a detecção precoce de cianobactérias tóxicas em mananciais é muito importante, a fim de evitar problemas de contaminação e de saúde pública. Sem a possibilidade de distinção morfológica entre as linhagens tóxicas e não tóxicas de cianobactérias, a utilização de análises moleculares pode ser aplicada para o monitoramento da qualidade da água em reservatórios, por possibilitar a diferenciação entre a ocorrência de genótipos tóxicos e não tóxicos (BITTENCOURT-OLIVEIRA; SANTOS; MOURA, 2010; BITTENCOURT-OLIVEIRA, et al., 2012). No Brasil, a maioria (82\%) das linhagens de cianobactérias isoladas em ambientes de água doce são produtoras de toxinas quando testados por imunoensaios ou análises de HPLC (SOARES; MAGALHÃES; AZEVEDO, 2004).

Quadro 3.1 - Exemplos de gêneros de cianobactérias potencialmente tóxicas encontradas em ecossistemas aquáticos

\begin{tabular}{|l|l|}
\hline \multicolumn{1}{|c|}{ Gêneros de cianobactérias } & Referências \\
\hline \multirow{4}{*}{ Aphanizomenon } & Sinoven e Jones (1999) \\
& Komárek et al. $(2001)$ \\
& Codd et al. $(2005)$ \\
& Melcher (2008) \\
& WHO (2008) \\
\hline \multirow{5}{*}{ Cylindrospermopsis } & Carmichael et al. (2001) \\
& Bittencourt-Oliveira e Molica (2003) \\
& Melcher (2008) \\
& Schaker (2012) \\
& Hoff-Risseti et al. (2013) \\
\hline \multirow{3}{*}{ Dolichospermum (Anabaena) } & Codd (1995) \\
& Carmichael et al. (2001) \\
& Soares et al. (2006) \\
& WHO (2008) \\
& Sá et al. (2010) \\
\hline
\end{tabular}




\begin{tabular}{|c|c|}
\hline Gêneros de cianobactérias & Referências \\
\hline Lyngbya & $\begin{array}{l}\text { Carmichael } \text { et al. (1997) } \\
\text { Seifert } \text { et al. (2007) } \\
\text { Foss (2011) } \\
\text { Mihali, Charmichael e Neilan (2011) } \\
\text { Lajeunesse } \text { et al. (2012) }\end{array}$ \\
\hline Microcystis & $\begin{array}{l}\text { Carmichael } \text { et al. (2001) } \\
\text { WHO (2008) } \\
\text { Wu } \text { et al. (2012) } \\
\text { Bittencourt-Oliveira } \text { et al. (2014) } \\
\text { Wu } \text { et al. (2014) }\end{array}$ \\
\hline Nodularia & $\begin{array}{l}\text { Carmichael (1992) } \\
\text { Koskenniemi } \text { et al. (2007) } \\
\text { WHO (2008) } \\
\text { Fewer } \text { et al. (2013) } \\
\text { Mazur-Marzec } \text { et al. (2013) }\end{array}$ \\
\hline Nostoc & $\begin{array}{l}\text { Sivonen } \text { et al. }(1990) \\
\text { Codd (1995) } \\
\text { Vieira } \text { et al. }(2005) \\
\text { WHO (2008) } \\
\text { Li } \text { et al. }(2010)\end{array}$ \\
\hline Oscillatoria & $\begin{array}{l}\text { Carmichael (1990) } \\
\text { Carmichael (1992) } \\
\text { Vieira et al. }(2005) \\
\text { Mazmouz } \text { et al. }(2010) \\
\text { Méjean } \text { et al. }(2010)\end{array}$ \\
\hline Planktothrix & $\begin{array}{l}\text { Vieira et al. (2005) } \\
\text { WHO (2008) } \\
\text { Ostermaier } \text { et al. (2013) } \\
\text { Akçaalan } \text { et al. (2014) } \\
\text { Bittencourt-Oliveira } \text { et al. (2014) }\end{array}$ \\
\hline
\end{tabular}

Fonte: Elaborado pela autora

As cianotoxinas podem ser classificadas de acordo com sua ação em: hepatotoxinas (microcistinas, nodularinas), neurotoxinas (anatoxinas, saxitoxinas), citotoxinas (cilindrospermopsinas), toxinas irritantes da pele - dermatotoxinas (endotoxinas lipopolissacarídicas - LPS) e toxinas gastrointestinais (CARMICHAEL, 1992; ZEGURA; STRASER; FILIPIC, 2011). A estrutura química de algumas cianotoxinas, descritas com maiores detalhes, pode ser visualizada na Figura 3.1. 


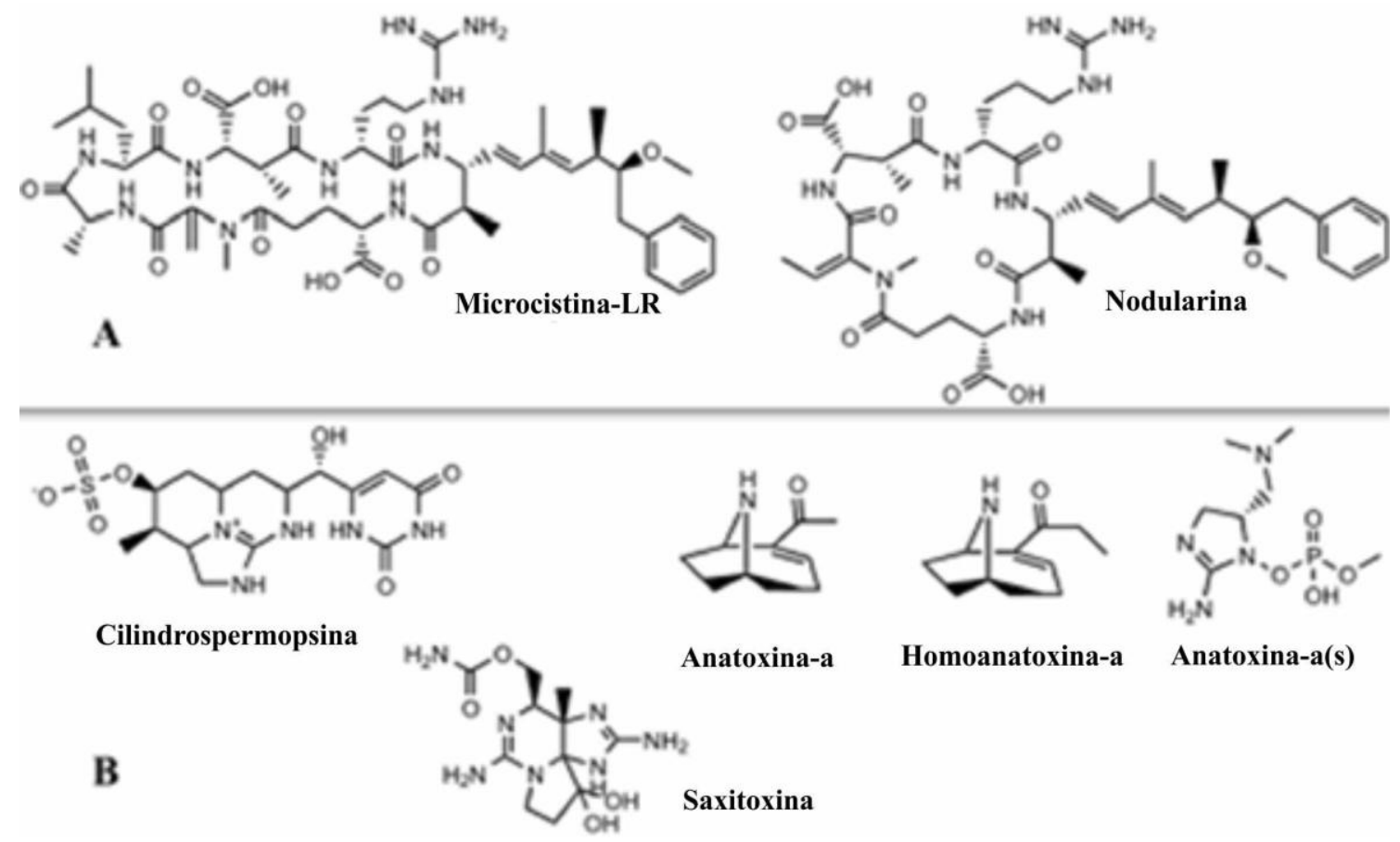

Figura 3.1 - Estrutura química de cianotoxinas

A. Microcistina-LR (a forma mais tóxica de microcistina, onde os aminoácidos variáveis são leucina e arginina) e nodularina.

B. Toxinas alcaloides: cilindrospermopsina, saxitoxina, anatoxina-a, homoanatoxina-a, anatoxina-a(s).

Fonte: Neilan et al. (2013)

As microcistinas são polipeptídeos hepatotóxicos, de baixo peso molecular, com diferentes graus de potência. O principal modo de ação é a inibição das proteínas fosfatases 1 e 2A de modo específico e irreversível, o que pode danificar o suprimento energético da célula (AMÉ; DEL PILAR DÍAZ; WUNDERLIN, 2003; CARMICHAEL, 1994; FALCONER, 2008; HILBORN et al., 2013; MACKINTOSH et al., 1990), causando a deformação celular do hepatócito, pela ruptura do citoesqueleto dessas células (FALCONER, 2008). Essa toxina possui aminoácidos variáveis que dão origem a mais de 80 isoformas estruturais diferentes de microcistinas, cada uma exibindo um perfil de toxicidade diferente (PEARSON; NEILAN, 2008).

Dentre os efeitos nocivos das microcistinas temos: aumento da mortalidade, lesão hepática, dano renal e evidências de efeito promotor de tumores (carcinogênese hepática) (BLÁHA; BABICA; MARSÁLEK, 2009). A Organização Mundial de Saúde (OMS) recomenda um valor de referência de $1 \mu \mathrm{g} / \mathrm{L}$, como valor máximo de exposição à microcistina-LR para animais e humanos (WHO, 1998; 2008). A portaria MS no 2.914 de 
12/12/2011, de potabilidade da água, utiliza o mesmo valor de referência, adotado pela OMS, quanto à exposição às microcistinas.

A estrutura química das microcistinas são produtos de NRPSs. A sequência de DNA (2kb) codificando uma NRPS foi identificada pela primeira vez no genoma da linhagem Microcystis aeruginosa PCC 7806, uma linhagem produtora de microcistina. O grupo completo de genes, envolvidos na síntese de microcistinas, foi então sequenciado. Esse grupo compreende 10 genes (mcyA-J) (Figura 3.2), arranjados em dois operons descritos divergentemente, consistindo de mcyA-C e mcyD-J (MÉJEAN; PLOUX, 2013; TILLETT et $a l ., 2000)$. A organização dos operons e genes variam nos gêneros em que foram descritos: Microcystis, Dolichospermum (Anabaena) e Planktothrix (DITTMANN; FEWER; NEILAN, 2013).

STRAUB et al. (2011) utilizaram o genoma de Microcystis aeruginosa PCC 7806 para estudar a dinâmica da expressão genômica nesta cianobactéria, durante ciclos de luz e escuro, e revelaram que a biossíntese de metabólitos secundários, como as microcistinas, ocorre essencialmente durante o período de luz, sendo a luz um fator crítico para essa espécie, como para outros micro-organismos fotossintéticos.

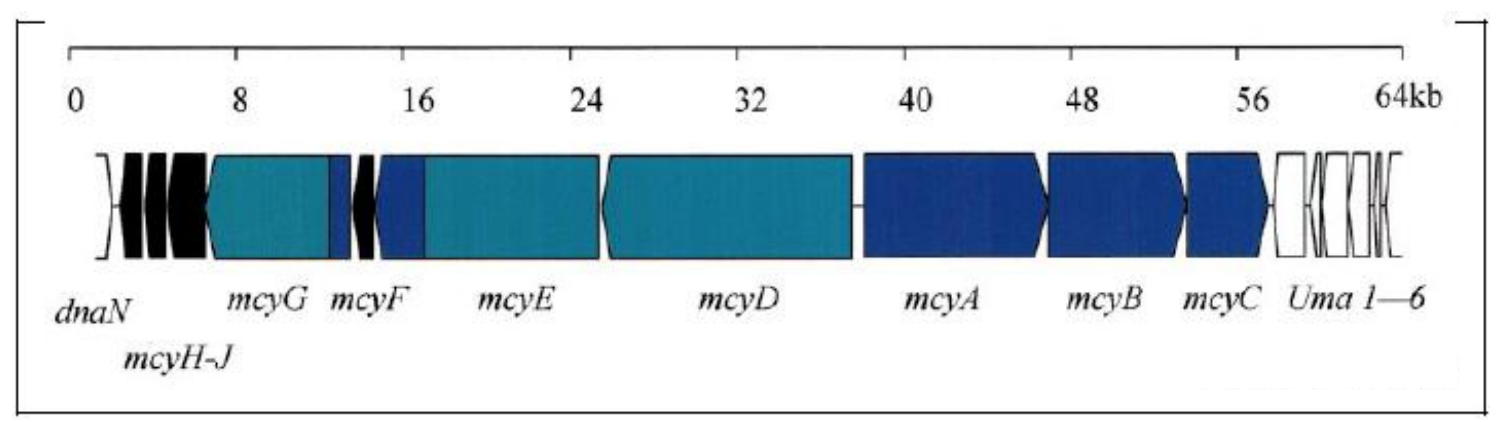

Figura 3.2 - Organização do agrupamento de genes responsáveis pela biossíntese da microscitina

Fonte: Tillet et al. (2000)

Outra toxina pertencente à família dos peptídeos cíclicos é chamada de nodularina, com propriedades químicas semelhantes à microcistina (CARMICHAEL, 1992). Microcistinas e nodularinas são as cianotoxinas mais frequentemente relatadas em ambientes de água doce eutrofizados (SINOVEN; JONES, 1999), e foram originalmente isoladas de linhagens dos gêneros Microcystis e Nodularia, respectivamente (CHORUS; BARTRAM, 1999). A toxicidade das nodularinas também ocorre devido à inibição das proteínas fosfatases 
1 e 2A. Elas podem também induzir estresse oxidativo intracelular e são consideradas promotoras de tumores (CHEN; SHEN; FANG, 2013; UFELMANN et al., 2012).

As neurotoxinas interferem no funcionamento do sistema nervoso levando à paralisia dos músculos respiratórios. Quatro neurotoxinas têm sido estudadas detalhadamente: anatoxina-a, anatoxina-a(s), saxitoxina e neosaxitoxina (CARMICHAEL, 1992; CHORUS; BARTRAM, 1999). Espécies e linhagens de Dolichospermum (Anabaena) produzem neurotoxinas, chamadas anatoxinas. Linhagens de Aphanizomenon flos-aquae produzem saxitoxina e neosaxitoxina. (CARMICHAEL; MAHMOOD; HYDE, 1990).

Anatoxina-a é um pequeno alcaloide neurotóxico, que atua na junção neuromuscular, causando descarga espontânea e morte, eventualmente, por insuficiência respiratória (DEVLIN et al., 1977; FALCONER, 2008). Anatoxina-a(s) provoca salivação, lacrimação, incontinência urinária, ataxia e convulsões. A morte é geralmente o resultado de um colapso respiratório (MATSUNAGA et al., 1989). No sul do Brasil foi detectada a presença de Dolichospermum (Anabaena) crassa, em reservatório de abastecimento de água da cidade de Caxias do Sul, constatando a presença de anatoxina-a(s) (BECKER et al., 2010).

As saxitoxinas ou PSP (Paralytic Shellfish Poisons) são alcaloides que bloqueiam os canais de sódio nos axônios, provocando paralisia (FALCONER, 2008). Apesar do conhecimento sobre a função das saxitoxinas e seus análogos (por exemplo, a neosaxitoxina) como bloqueadores de canais de sódio, o efeito dessas toxinas sobre o ambiente e os genes que são responsáveis pela sua produção, ainda precisam de elucidação mais detalhada, principalmente no que diz respeito ao seu papel nos organismos potencialmente produtores dessas toxinas (WIESE et al., 2010).

As espécies de cianobactérias potencialmente tóxicas: Microcystis spp., Planktothrix agardhii, Radiocystis fernandoi, Pseudanabaena mucicola e Cylindrospermopsis raciborskii, foram detectadas em reservatórios de água brasileiros, sendo consideradas responsáveis pela produção de saxitoxinas e neosaxitoxinas (ANJOS et al., 2006; MOLICA et al., 2005; MONTEIRO et al., 2014).

As cilindrospermopsinas são alcaloides que causam danos ao fígado, rins, trato gastrointestinal, órgãos endócrinos, sistema imune, sistema vascular e muscular. Elas inibem a síntese de proteínas (FALCONER, 2008; FROSCIO et al., 2008). As cilindrospermopsinas são toxinas especialmente perigosas porque os sintomas clínicos podem se manifestar somente vários dias após exposição, sendo então, difícil correlacionar os efeitos tóxicos (MANKIEWICZ et al., 2003). 
A toxicidade em linhagens de Cylindrospermopsis raciborskii depende da presença do grupo de genes, denominados gene $c y r$, sendo este grupo responsável pela síntese de cilindrospermopsinas (SINHA et al., 2014). As espécies Sphaerospermopsis aphanizomenoides (anteriormente denominada Aphanizomenon aphanizomenoides Forti) e $C$. raciborskii, potencialmente produtoras de cilindrospermopsina, já foram detectadas na comunidade fitoplanctônica de reservatórios brasileiros (BITTENCOURT-OLIVEIRA et al., 2011). Além da cilindrospermopsina, microcistina também já foi detectada em vários reservatórios do Nordeste brasileiro. Dentre as cianobactérias identificadas podemos destacar: C. raciborskii, Planktothrix agardhii, Microcystis panniformis (BITTENCOURT-OLIVEIRA et al., 2014).

As endotoxinas lipopolissacarídicas - LPS são componentes integrais da parede celular de todas as bactérias Gram-negativas e de cianobactérias, e podem induzir uma resposta alérgica em humanos e outros mamíferos. Os sintomas da exposição incluem irritação na pele e nos olhos e distúrbios gastrointestinais (CHEN; BURKE; PREPAS, 2011). Como todas as cianobactérias contem lipopolissacarídeos (LPS) em suas paredes celulares, as concentrações dessa substância aumentam com a densidade celular na água (WATSON et al., 2015).

Acredita-se que as cianotoxinas sejam importantes na comunidade do fitoplâncton, porém, o papel fisiológico e ecológico dos compostos não é claro (BÁCSI; BBÉRES; VASAS, 2013; FLYNN, 2008; SVERCEL, 2013). As cianotoxinas, possivelmente, possuem múltiplas funções, variando com a toxina em particular e com suas espécies produtoras. As possíveis vantagens relacionadas à produção das toxinas estão agrupadas em dois temas: vantagens competitivas e auxílio fisiológico. O primeiro tema está ligado aos mecanismos de defesa celular, resposta à herbivoria e/ou competição por recursos ambientais. O segundo tema - fisiológico - considera que estes metabólitos secundários melhoram a fisiologia celular através de benefícios para a homeostase, eficiência fotossintética e taxas de crescimento aceleradas (HOLLAND; KINNEAR, 2013; VALÉRIO; CHAVES; TENREIRO, 2010; TWISS; GOUVEA, 2006.).

\subsection{Florações de cianobactérias}

No ambiente aquático, a espécie do fitoplâncton que é capaz de competir com sucesso, por exemplo, pelos nutrientes disponíveis, tem o potencial de tornar-se dominante por aumentar a sua biomassa, formando florações (GRANÉLI; WEBERG; SALOMON, 
2008). As cianobactérias, ocasionalmente, podem dominar o fitoplâncton de lagos, reservatórios e rios. A ocorrência e abundância de vários tipos de cianobactérias dominantes nas florações não dependem de um único estímulo ambiental, mas de um conjunto de fatores com ação recíproca, como a intensidade da luz, as alterações climáticas sazonais, a temperatura e a disponibilidade de nutrientes (OLIVER; GANF, 2000).

Segundo Newcombe et al. (2012), a proliferação de cianobactérias em ambientes aquáticos é favorecida pela entrada de nutrientes, que pode estar relacionada com o aumento da urbanização, de práticas agrícolas modernas, da erosão de solos fertilizados, da ocorrência de temperaturas mais elevadas, do reduzido fluxo de rios, associado à condições de seca.

Davis et al. (2009) constataram que a temperatura mais elevada da água (13 a $30^{\circ} \mathrm{C}$ ) aumenta o percentual de Microcystis tóxicas e o número de cópias do gene $m c y D$ gene envolvido na síntese de microcistinas em cianobactérias - por célula, o que pode produzir florações com maior concentração de toxina em um ecossistema.

O enriquecimento (elevação da concentração de nutrientes) de corpos d'água juntamente com as mudanças nas condições climáticas contribuem para a frequência, intensidade e distribuição de florações tóxicas de cianobactérias no ambiente. Além do mais, a regulação dos genes e da produção de toxinas pela luz solar, parece ser universal entre as cianobactérias, sugerindo uma ligação entre a produção de toxinas e a fotossíntese (NIELAN et al., 2013).

Diversos trabalhos têm demostrado que a acentuada eutrofização dos corpos hídricos, resultado da entrada massiva de nutrientes (principalmente $\mathrm{N}$ e P), esteja possivelmente relacionada ao aumento na prevalência de florações de cianobactérias potencialmente produtoras de toxinas no ambiente aquático (EPA, 2016; HOLLAND; KINNEAR, 2013; ISLES et al., 2015; MA et al., 2014a; MA et al., 2014b; NYBOM, 2013; O’NEIL et al., 2012; PAERL; HALL; CALANDRINO, 2011; WATSON et al., 2015.).

A salinização, o conteúdo de ferro $(\mathrm{Fe})$ e outros metais traços, baixas taxas de herbivoria (PAERL; OTTEN, 2013), a baixa relação N:P e a estabilidade da coluna d'água, também são apontados, na literatura, como fatores responsáveis pela formação de florações de cianobactérias (CORDEIRO-ARAÚJO et al., 2010; FERNANDES et al., 2009; MANKIEWICZ et al., 2003;).

Análises de amostras de água do reservatório Vargem das Flores, localizado no estado de Minas Gerais, região sudeste do Brasil, indicaram que no período chuvoso ocorreram as maiores mudanças na coluna d'água e caracterizou o período de ocorrência de cianobactérias. Uma vez que as cianobactérias tenham um período de ocorrência definido, 
algumas ações preventivas devem ser aplicadas nesta época do ano, a fim de evitar problemas relacionados à presença de cianobactérias potencialmente tóxicas (GOMES et al., 2012). O esquema representativo do conjunto de fatores que influenciam a ocorrência das florações de cianobactérias pode ser observado na Figura 3.3.

Algumas medidas de manejo que levem à redução do processo de eutrofização, com manutenção do equilíbrio das concentrações de nutrientes (fósforo e nitrogênio), são colocadas como formas adequadas para prevenir a ocorrência de florações de cianobactérias em ambientes aquáticos (CHISLOCK et al., 2013; MA et al., 2014b; MARZOUK et al. 2013; MOSCHINI-CARLOS; NISHIMURA; POMPÊO, 2011; PAERL; HALL; CALANDRINO, 2011; PAERL; OTTEN, 2013; SANCHES et al. 2012; SMITH; SCHINDLER, 2009; von SPERLING; FERREIRA; GOMES, 2008; WANG et al., 2012;). Além do controle da eutrofização, a manutenção de programas de monitoramento deveria ser uma das ações para evitar problemas relacionados à presença de cianobactérias em reservatórios de água (GOMES et al., 2012).

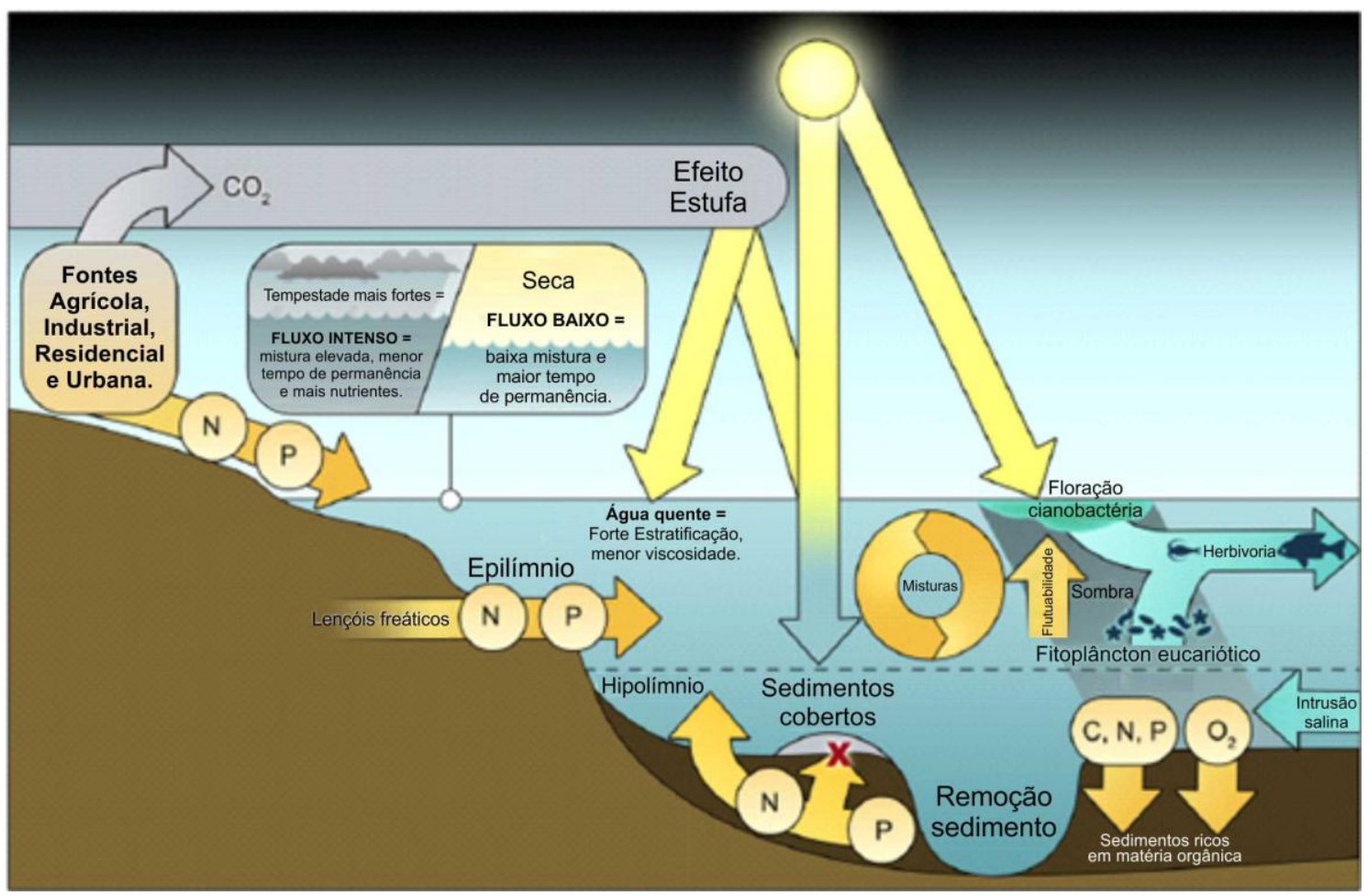

Figura 3.3 - Figura esquemática ilustrando os processos ambientais que influenciam a ocorrência de florações de cianobactérias

Fonte: Paerl, Hall e Calandrino (2011) 


\subsection{Ocorrência de florações de cianobactérias tóxicas}

\subsubsection{Episódios de florações no mundo e no Brasil}

Francis (1878) descreveu o primeiro episódio de morte de animais, após ingestão de água contendo cianobactérias (Nodularia spumigera) no lago Alexandria, na Austrália. O primeiro registro de intoxicação humana por cianotoxinas ocorreu em 1930, na cidade de Charleston (EUA) onde um surto gastrointestinal afetou aproximadamente 10.000 pessoas. Exames microscópicos de amostras da água revelaram crescimento abundante de cianobactérias de diferentes espécies (TISDALE, 1931).

Diversos eventos de florações de cianobactérias já foram relatados, em corpos hídricos, por todo o mundo (BECKER et al., 2006; HO e MICHALAK, 2015; ISLES et al., 2015; MA et al., 2014b; MICHALAK et al., 2013; MISHRA, D.; MISHRA, S., 2010; REJMÁNKOVÁ et al., 2011). Em muitos países já foram registradas intoxicações por cianotoxinas, oriundas da ocorrência de florações de cianobactérias. Além da Austrália e dos Estados Unidos, países como: Canadá, Inglaterra, China, Argentina, Colômbia e Uruguai já constataram a morte de animais domésticos e doenças em humanos, após o contato com água contendo cianotoxinas (CODD et al., 2015; DILLENBERG; DEHNEL, 1959; DORR et al., 2010; FALCONER et al., 1999; TURNER et al., 1990).

No Brasil, a presença de cianotoxinas em águas destinadas ao abastecimento humano foi responsável pela primeira confirmação no mundo de morte por cianotoxinas, conhecida como "Síndrome de Caruaru” (CARMICHAEL et al., 2001). Na água utilizada em uma clínica de hemodiálise, no município de Caruaru/PE, foram identificados dois grupos de cianotoxinas - microcistina e cilindrospermopsina - nos exames do fitoplâncton das amostras de água, no sistema de tratamento de água da clínica, e no tecido hepático dos pacientes (AZEVEDO et al., 2002; CARMICHAEL et al., 2001; JOCHIMSEN et al., 1998; POURIA et al., 1998). O contato com a água contendo cianotoxinas durante o processo de diálise levou à morte de 76 pacientes (CARMICHAEL et al., 2001).

Vários registros da presença de cianobactérias potencialmente tóxicas, envolvidas em episódios de florações, foram relatados no Brasil, incluindo locais como o Rio Grande do Sul, Minas Gerais, Rio de Janeiro, São Paulo, Pernambuco e outros, conforme Quadro 3.2. 
Quadro 3.2 - Localidades no Brasil onde cianobactérias foram identificadas

\begin{tabular}{|c|c|c|}
\hline Localidade & Cianobactérias identificadas & Referências \\
\hline Rio Grande do Sul (RS) & $\begin{array}{l}\text { Aphanotece, Dolichospermum, Microcystis } \\
\text { spp., Dolichospermum (Anabaena), } \\
\text { Sphaerocavum cf. brasiliense, Planktothrix, } \\
\text { Cylindrospermopsis }\end{array}$ & $\begin{array}{l}\text { Matthiensen, Yunes e } \\
\text { Codd (1999) } \\
\text { Carvalho } \text { et al. }(2008) \\
\text { Chaves } \text { et al. }(2009) \\
\text { Domingues } \text { et al. }(2011) \\
\text { Becker } \text { et al. }(2010)\end{array}$ \\
\hline Minas Gerais (MG) & $\begin{array}{l}\text { Microcystis novacekii } \\
\text { Dolichospermum (Anabaena) } \\
\text { Sphaerocavum brasiliensis, Microcystis } \\
\text { spp. }\end{array}$ & $\begin{array}{l}\text { Figueredo, Giani, Bird } \\
(2007) \\
\text { Freitas et al. }(2012) \\
\text { Jardim } \text { et al. } \text { (2014) } \\
\text { Mello e Maia-Barbosa } \\
(2015)\end{array}$ \\
\hline Rio de Janeiro (RJ) & $\begin{array}{l}\text { Chlorococcales e Microcystis } \\
\text { Cylindrospermopsis raciborskii, } \\
\text { Planktothrix agardhii }\end{array}$ & $\begin{array}{l}\text { Magalhães, Soares e } \\
\text { Azevedo (2001) } \\
\text { Ferrão-Filho et al. (2009) } \\
\text { Bonilla et al. (2012) } \\
\text { Cruz, Oliveira e Gômara } \\
\text { (2012) }\end{array}$ \\
\hline São Paulo (SP) & $\begin{array}{l}\text { Microcystis aeruginosa; } \\
\text { Microcystis spp., Planktothrix agardhii, } \\
\text { Radiocystis fernandoi, Pseudanabaena } \\
\text { mucicola, Cylindrospermopsis raciborskii }\end{array}$ & $\begin{array}{l}\text { Azevedo et al. (1994) } \\
\text { Anjos et al. (2006) } \\
\text { Sotero-Santos et al. } \\
(2006) \\
\text { Tundisi et al. (2015) }\end{array}$ \\
\hline Distrito Federal (DF) & Cylindrospermopsis raciborskii & $\begin{array}{l}\text { Branco e Senna (1991) } \\
\text { Branco e Senna (1994) }\end{array}$ \\
\hline Pará (PA) & $\begin{array}{l}\text { Dolichospermum (Anabaena), Microcystis, } \\
\text { Oscillatoria, Aphanizomenon, Nostoc, } \\
\text { Planktothrix, Radiocystis }\end{array}$ & $\begin{array}{l}\text { Vieira } \text { et al. }(2005) \\
\text { Sá et al. }(2010) \\
\text { Silva, S. }(2012) \\
\text { Costa } \text { et al. }(2014)\end{array}$ \\
\hline $\begin{array}{l}\text { Rio Grande do Norte } \\
(\mathrm{RN})\end{array}$ & $\begin{array}{l}\text { C. raciborskii, Microcystis spp e } \\
\text { Aphanizomenon ssp., Dolichospermum } \\
\text { (Anabaena) circinalis }\end{array}$ & $\begin{array}{l}\text { Costa et al. }(2006) \\
\text { Panosso et al. }(2007) \\
\text { Chellappa } \text { et al. }(2008) \\
\end{array}$ \\
\hline Pernambuco (PE) & $\begin{array}{l}\text { C. raciborskii Planktothrix agardhii, } \\
\text { Sphaerospermopsis aphanizomenoides, } \\
\text { Microcystis spp., } \\
\text { Geitlerinema amphibium, Synechocystis } \\
\text { aquatilis } \\
\text { Coelomoron tropicale }\end{array}$ & $\begin{array}{l}\text { Silva, E. et al. (2013) } \\
\text { Bittencourt-Oliveira } \text { et al. } \\
\text { (2014) }\end{array}$ \\
\hline Bahia (BA) & $\begin{array}{l}\text { Dolichospermum (Anabaena), Microcystis } \\
\text { Trichodesmium erythraeum, } \\
\text { Cylindrospermopsis }\end{array}$ & $\begin{array}{l}\text { Teixeira et al. (1993) } \\
\text { Lima et al. }(2013) \\
\text { Affe } \text { et al. }(2016)\end{array}$ \\
\hline Paraíba (PB) & $\begin{array}{l}\text { Planktothrix agardhii, C. raciborskii, } M . \\
\text { aeruginosa, Aphanocapsa, Oscillatoria, } \\
\text { Dolichospermum (Anabaena) }\end{array}$ & $\begin{array}{l}\text { Torquato (2012) } \\
\text { Monteiro et al. }(2014) \\
\text { Lins et al. }(2016)\end{array}$ \\
\hline Ceará (CE) & $\begin{array}{l}\text { Cylindrospermopsis raciborskii, } \\
\text { Aphanocapsa, Merismopedia, Chroococcus, } \\
\text { Aphanothece, Microcystis. }\end{array}$ & $\begin{array}{l}\text { Costa (2010) } \\
\text { Lucas et al. (2013) }\end{array}$ \\
\hline
\end{tabular}




\begin{tabular}{|l|l|l|}
\hline \multicolumn{3}{|l|}{ Quadro 3.2-Localidades no Brasil onde cianobactérias foram identificadas (Continuação) } \\
\hline Localidade & \multicolumn{2}{|c|}{ Referências } \\
\hline Espírito Santo (ES) & $\begin{array}{l}\text { Pseudoanabaena identificadas moniliformis, C. } \\
\text { raciborskii, Synechococcus nidulans, } \\
\text { Synechococcus sp e Synechocystis sp }\end{array}$ & $\begin{array}{l}\text { Kotaka, LEITE, e } \\
\text { GADOTTI (2005) } \\
\text { FUNASA (2007) }\end{array}$ \\
\hline Paraná (PR) & C. raciborskii & $\begin{array}{l}\text { Gomes (2011) } \\
\text { Beló (2015) }\end{array}$ \\
\hline Santa Catarina (SC) & C. raciborskii & Moser (2011) \\
\hline Goiás (GO) & $\begin{array}{l}\text { Microcystis spp., Aphanocapsa, } \\
\text { Oscillatoria }\end{array}$ & Pimentel et al. (2015) \\
\hline Tocantins (TO) & C. raciborskii, Dolychospermum solitarium & Silva, J. et al. (2015) \\
\hline
\end{tabular}
Fonte: Elaborado pela autora

\subsection{Métodos analíticos utilizados para detecção de cianobactérias e cianotoxinas}

3.5.1 Metodologias para identificação taxonômica e quantificação de cianobactérias

A identificação e a quantificação de cianobactérias em reservatórios de água se faz necessário para o monitoramento de cianotoxinas, podendo fornecer um sistema precoce de alerta sobre o desenvolvimento de florações potencialmente tóxicas. Avanços nas ferramentas diagnósticas têm ajudado a caracterizar as cianobactérias e cianotoxinas, incluindo: uso de microscopia óptica e de fluorescência para a taxonomia de cianobactérias; e a identificação e caracterização de cianotoxinas usando ensaios bioquímicos (inibição de atividades enzimáticas), analíticos (cromatografia de alta resolução e a espectrometria de massa) e moleculares (PCR) (HARADA; KONDO; LAWTON, 1999; LAWTON et al., 1999; SILVA, C. et al., 2012).

A microscopia é utilizada para identificação e baseia-se em critérios morfológicos. Os taxonomistas devem ter habilidade e experiência para identificação adequada dos gêneros e espécies. Dois tipos de microscópios são comumente usados: (1) microscópio composto padrão e (2) o microscópio invertido (KARLSON et al., 2010). Em conjunto com a microscopia, o método de Utermöhl é adequado para a quantificação do fitoplâncton, incluindo as cianobactérias (MÜLLER; RAYA-RODRIGUEZ; CYBIS, 2010).

O método de Utermöhl pode ser útil tanto para identificação quanto para quantificação desses organismos. Essa metodologia baseia-se na sedimentação de uma alíquota de amostra de água, em uma câmara. A gravidade provoca a fixação das células no fundo da câmara, e as células fixadas podem ser identificadas e enumeradas usando um 
microscópio invertido. Para quantificar o resultado como células por litro, um fator de conversão deve ser determinado. A desvantagem do método é o tempo necessário para análise de cada amostra, além de pessoal treinado, principalmente no que diz respeito à taxonomia. $\mathrm{O}$ tempo de sedimentação dificulta a análise imediata da amostra (EDLER; ELBRÄCHTER, 2010).

\subsubsection{O uso de marcadores moleculares via PCR para detecção de cianobactérias}

O uso da taxonomia clássica, bem como, dos métodos analíticos para análise qualitativa e quantitativa de cianobactérias em amostras ambientais, fazem parte das metodologias empregadas atualmente no monitoramento de reservatórios de usos múltiplos. Porém, esses métodos muitas vezes requerem, dentre vários fatores, de tempo e acurácia do analista para obtenção dos resultados, e então, surge à necessidade de utilização de uma metodologia diagnóstica sensível e de fácil manuseio para obtenção de resultados rápidos, no que diz respeito à presença de cianobactérias potencialmente tóxicas em amostras de água.

Linhagens tóxicas e não-tóxicas de cianobactérias podem ser detectadas, por meio de técnicas moleculares, sendo úteis para a identificação precoce da ocorrência de espécies potencialmente tóxicas. Abordagens moleculares podem também ser úteis para fornecer informações sobre a abundância e dominância das principais espécies tóxicas e, assim, podem ser inseridas no desenvolvimento de métodos de análise e monitoramento da qualidade da água, disponíveis para estratégias de controle da ocorrência de cianobactérias em ambientes aquáticos (MIHALI et al., 2011; SRIVASTAVA et al., 2013).

Dentre as diversas técnicas moleculares que podem ser utilizadas com essa finalidade destaca-se a reação em cadeia da polimerase (PCR). Muller e Faloona (1987) desenvolveram essa metodologia, por meio da qual, uma sequência de ácido nucleico pode ser amplificada exponencialmente in vitro. A PCR é um procedimento que possibilita a amplificação de fragmentos de DNA específicos, partindo-se de uma quantidade mínima de DNA alvo, que consiste em ciclos repetitivos. Para a aplicação da técnica são necessários: a dupla fita de DNA para servir de molde e a construção de dois oligonucleotídeos específicos desenhados de modo a flanquear a sequência a ser amplificada (CHEN; BURKE; PREPAS, 2011; LIMA, 2008;).

As técnicas moleculares baseadas nos ensaios de PCR convencional ou em variações dessa ferramenta, tais como PCR em tempo real e PCR múltipla, podem ser úteis 
para detecção e/ou quantificação de genes de biossíntese de cianotoxinas, como as microcistinas e nodularinas. Essas abordagens permitem a identificação de cianobactérias potencialmente produtoras de toxinas (DITTMANN; FEWER; NEILAN, 2013; PEARSON et al., 2016), sendo importantes para o monitoramento da qualidade da água.

Alguns genes relacionados com a síntese de cianotoxinas, como os grupos de genes denominados $m c y$, cyr, sxt, ana, nda, envolvidos, respectivamente, com a síntese de microcistinas, cilindrospermopsinas, saxitoxinas, anatoxinas e nodularinas têm suas sequências oligonucleotídicas utilizadas para detecção de cianobactérias potencialmente tóxicas, por meio da técnica de PCR. A Figura 3.4 contém os grupos de genes responsáveis pela biossíntese de cianotoxinas, com ênfase para o agrupamento de genes relacionados com a síntese de microcistinas - mcy - gene alvo utilizado neste trabalho de pesquisa (ALTEBRINEH et al., 2010; AL-TEBRINEH et al., 2012; BURFORD et al., 2014; HA; HIDAKA; TSUNO, 2009; LI; GU; HE, 2014; NEILAN et al., 1997; RANTALA et al., 2011). Essas análises podem fornecer uma indicação do potencial para a produção de toxina em florações de cianobactérias (BITTENCOURT-OLIVEIRA; SANTOS; MOURA, 2010).

Outras sequências de iniciadores oligonucleotídicos utilizadas para identificação taxonômica e análise filogenética de cianobactérias, nos ensaios de PCR, incluem sequências referentes à porção $16 \mathrm{~S}$ do DNA ribossomal (DNAr) e às porções $c p c \mathrm{~A}$ e $c p c \mathrm{~B}$, incluindo o espaço intergênico (cpcBA-IGS), do operon da ficocianina. A ficocianina é um pigmento específico presente em cianobactérias (Figura 3.5) (LANE et al., 2012; NEILAN; JACOBS; GOODMAN, 1995; WEISBURG et al., 1991). 


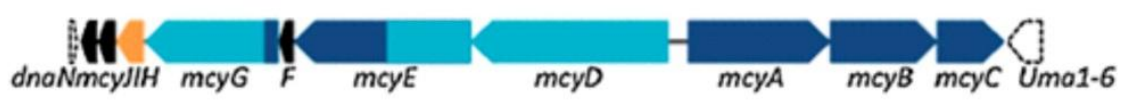

(a) Grupo de genes (mcy) sintetase de microcistinas, M. aeruginosa PCC 7806,55 kb

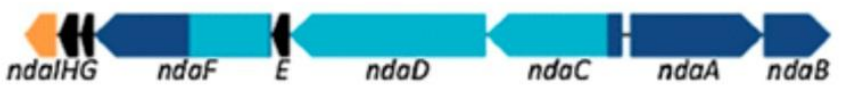

(b) Grupo de genes (nda) sintetase de nodularina, N. spumigena NSOR10, 48 kb

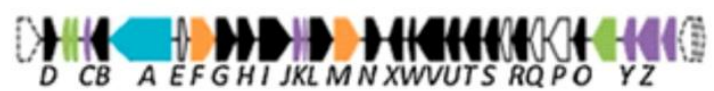

(c) Grupo de genes (sxt) sintetase de saxitoxina, C. raciborskii $\mathrm{T} 3,35 \mathrm{~kb}$

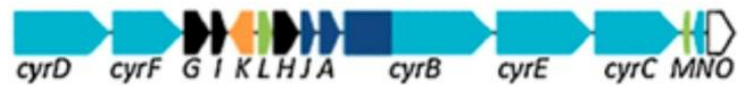

(d) Grupo de genes (cyr) sintetase de cilindrospermopsina, C. raciborskii AWT205, 43 kb

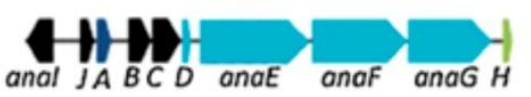

(e) Grupo de genes (ana) sintetase de anatoxina-a, Oscillatoria sp. PCC 6506, 29 kb

Figura 3.4 - Representação do grupo de genes de biossíntese de cianotoxinas

Fonte: Adaptado de Pearson et al. (2016).

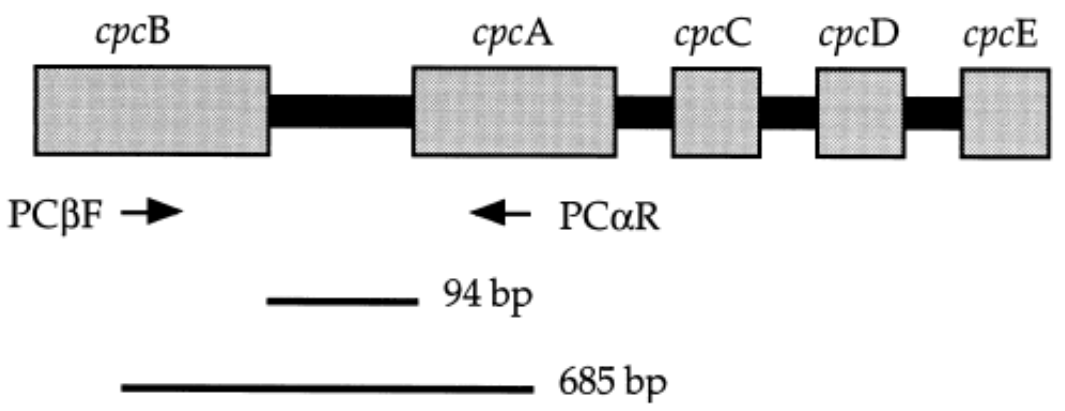

Figura 3.5 - Representação esquemática do operon da ficocianina Fonte: Neilan, Jacobs e Goodman, (1995)

A caracterização molecular de cianobactérias e suas toxinas, usando iniciadores oligonucleotídicos específicos, por meio das reações em cadeia da polimerase, vêm sendo utilizada por diversos pesquisadores em todo o mundo. A utilização de PCR e iniciadores específicos pode ainda ser utilizada para investigar além da diversidade filogenética de cianobactérias, sua significância ecológica (AMANN; LUDWIG; SCHLEIFER, 1995; NÜBEL et al., 1997).

Diversos trabalhos têm sido desenvolvidos utilizando amplamente os ensaios de PCR, a fim de monitorar a presença de cianobactérias potencialmente tóxicas em corpos 
d'água. Essa ferramenta foi utilizada para detecção de cianobactérias potencialmente produtoras de microcistinas em reservatórios no Nordeste do Brasil (BITTENCOURTOLIVEIRA; SANTOS; MOURA, 2010). Em conjunto com a taxonomia clássica, muitas cianobactérias tóxicas foram identificadas em diversos reservatórios brasileiros (Quadro 3.2).

DRUGA et al. (2013), utilizando reações de PCR tradicional, detectaram a presença de cianobactérias produtoras de microcistinas, por meio da amplificação de fragmentos referentes às regiões dos genes $m c y \mathrm{~A}, m c y \mathrm{~B}, m c y \mathrm{D}$ e $m c y \mathrm{E}$, usando oligunucleotídeos específicos, em águas doces na Romênia. Os autores afirmam que a identificação de genes responsáveis pela síntese de microcistinas, por PCR, é muito sensível, rápida, utiliza número pequeno de amostras e tempo reduzido para a realização dos ensaios.

BARÓN-SOLA et al., (2012) utilizaram a PCR múltipla para detectar simultaneamente cianobactérias potencialmente produtoras de microcistinas e cilindrospermopsinas, utilizando sequências específicas dos genes mcy e aoa, em amostras ambientais de um lago espanhol e de uma lagoa argentina. Os testes geraram produtos de amplificação esperados, confirmando a presença de cianobactérias produtoras de toxinas nas amostras avaliadas.

A técnica da PCR múltipla também foi utilizada para detecção de genes relacionados à síntese de microcistinas - $m c y \mathrm{E}(70 \%)$, nodularinas - $n d a \mathrm{~F}(51 \%)$ e saxitoxinas - sxtI (65\%), em amostras de florações de cianobactérias coletadas em fontes de água doce na Austrália (BAKER et al. 2013).

Al-Tebrineh et al. (2011) utilizaram reações de PCR quantitativa para detecção e quantificação de cianobactérias hepatotóxicas oriundas de reservatórios localizados na Turquia. Todas as amostras renderam amplicons com uma faixa de detecção de $10^{1}-10^{6}$ cópias do gene hepatotóxico por reação, indicando que todas as amostras continham linhagens potencialmente capazes de sintetizar toxinas.

Após a descoberta do mecanismo de síntese não-ribossomal da microcistina e do conjunto de genes relacionados à síntese dessa toxina ter sido isolado (gene mcy), o desenvolvimento de técnicas moleculares para detectar cianotoxinas progrediu rapidamente (CHEN; BURKE; PREPAS, 2011). Dessa forma, a utilização de marcadores moleculares, via PCR, para detecção de cianobactérias potencialmente tóxicas, de forma rápida e sensível, vem sendo explorada ao redor do mundo, resultando em diagnósticos precisos e capazes de detectar cianobactérias potencialmente tóxicas. 


\subsubsection{Metodologias para detecção de toxinas}

Informações obtidas a partir do exame microscópico dos taxa de cianobactérias podem influenciar na escolha do método de análise das cianotoxinas. Diferentes métodos bioquímicos/analíticos podem ser utilizados para detecção dos componentes tóxicos produzidos pelas cianobactérias. A metodologia analítica utiliza as propriedades físicoquímica das cianotoxinas, tais como, peso molecular, cromóforos e reatividade devido aos grupos funcionais presentes nas moléculas (HARADA; KONDO; LAWTON, 1999). O Quadro 3.3 resume algumas características relacionadas às metodologias analíticas das cianotoxinas.

Quadro 3.3 - Métodos de detecção e/ou quantificação de cianotoxinas

\begin{tabular}{|c|c|c|}
\hline Método & Toxinas & $\begin{array}{r}\text { Comentários } \\
\end{array}$ \\
\hline $\begin{array}{l}\text { Inibição da proteína } \\
\text { fosfatase }\end{array}$ & $\begin{array}{l}\text { Microcistina, } \\
\text { nodularina }\end{array}$ & $\begin{array}{l}\text { Muito sensível e requer o uso de } \\
\text { radioatividade ou colorimetria }\end{array}$ \\
\hline Acetilcolinesterase & Anatoxina-a(s) & $\begin{array}{l}\text { O método não é seletivo porque ele } \\
\text { pode detectar outros compostos tóxicos, } \\
\text { tais como, os pesticidas } \\
\text { organofosforados }\end{array}$ \\
\hline ELISA & $\begin{array}{l}\text { Microcistina, } \\
\text { nodularina, saxitoxina }\end{array}$ & $\begin{array}{l}\text { Muito sensível, específico e de fácil } \\
\text { operação para quantificação de } \\
\text { cianotoxinas }\end{array}$ \\
\hline HPLC & $\begin{array}{l}\text { Microcistinas, } \\
\text { nodularinas, anatoxina- } \\
\text { a, homoanatoxina-a, } \\
\text { cilindrospermopsina }\end{array}$ & $\begin{array}{l}\text { Combinado com detecção UV, os dados } \\
\text { são coletados a } 238 \mathrm{~nm} \text { para detecção de } \\
\text { microcistinas. Solventes são utilizados, } \\
\text { como por exemplo, o metanol }\end{array}$ \\
\hline $\mathrm{LC} / \mathrm{MS}$ & $\begin{array}{l}\text { Microcistinas, } \\
\text { nodularinas, anatoxina- } \\
\text { a, homoanatoxina-a, } \\
\text { saxitoxina }\end{array}$ & $\begin{array}{l}\text { Permite a separação simultânea e a } \\
\text { identificação de microcistinas em uma } \\
\text { mistura, por exemplo }\end{array}$ \\
\hline MALDI & $\begin{array}{l}\text { Microcistinas, } \\
\text { nodularinas }\end{array}$ & $\begin{array}{l}\text { Fornece a massa molecular de todos os } \\
\text { peptídeos em uma amostra, e dessa } \\
\text { forma, indica as cianotoxinas presentes }\end{array}$ \\
\hline
\end{tabular}

Fonte: Adaptado de Harada; Kondo e Lawton (1999)

Dentre as metodologias utilizadas para detecção e quantificação de cianotoxinas destaca-se o teste de ELISA (do inglês enzyme linked immunosorbent assay). Kfir, Johannsen e Botes (1986) foram os pioneiros na produção de anticorpos monoclonais específicos para as toxinas de $M$. aeruginosa. Dessa forma, tornou-se possível a detecção de baixas concentrações dessas toxinas em reservatórios e na água potável, por meio do teste de ELISA, com a ajuda desses anticorpos.

O método de ELISA pode ser utilizado para quantificar concentrações de microcistinas por meio de um processo de ligação competitiva entre a toxina, quando presente em uma amostra, e um análogo de microcistina, contido no teste, pelo sítio de ligação do 
anticorpo em solução. A concentração da toxina é visualizada por um processo de desenvolvimento da cor e é inversamente proporcional à cor desenvolvida (por exemplo, quanto mais escura a cor da amostra, menos toxina presente) com uma relação não linear. Durante o teste, um número de soluções-padrão com concentrações conhecidas de toxina são usadas para desenvolver uma curva padrão, um modelo matemático de densidade óptica (OD) em função das concentrações de toxina (QIAN et al., 2015). 


\section{METODOLOGIA}

\subsection{Descrição da área de estudo: lago Paranoá}

Em 1959, o represamento do rio Paranoá originou o lago homônimo ao inundar os terrenos situados abaixo da cota de 1.000 metros de altitude em relação ao nível do mar (ADASA, 2011a). O lago possui 37,5 $\mathrm{Km}^{2}$ de área superficial (FERRER; DEL NEGRO, 2012), e teve seu enchimento finalizado em 1960 (Figura 4.1). O lago possui quatro braços, que são frutos dos antigos vales dos tributários Bananal e Torto ao norte e Riacho Fundo e Gama ao sul (Figura 4.2).

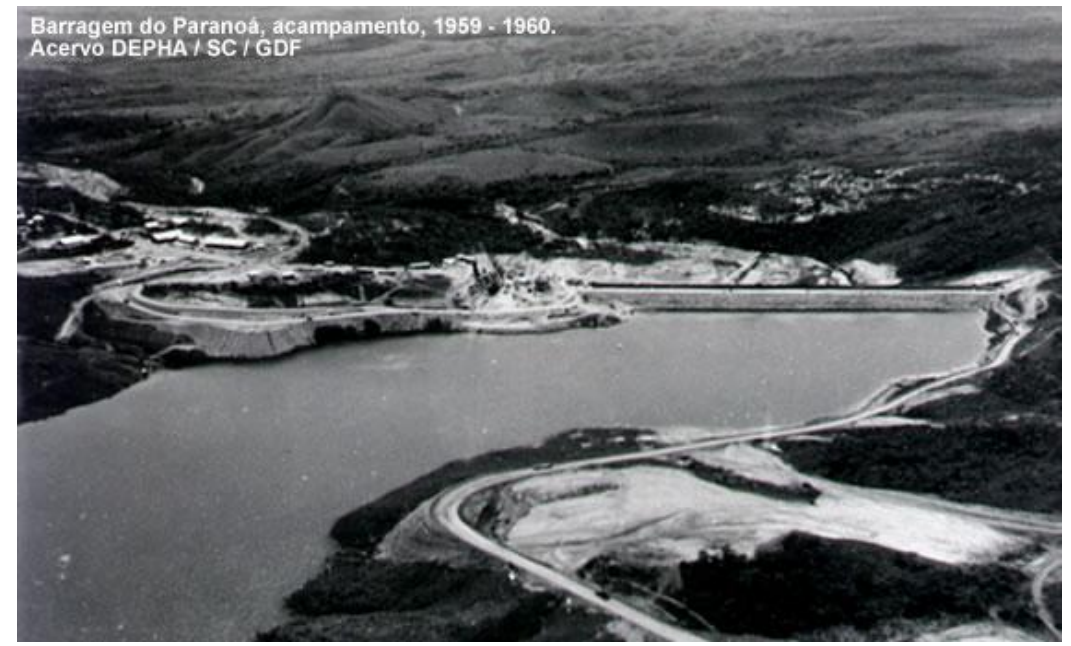

Figura 4.1 - Barragem do Paranoá

Disponível em: CAESB (2011a)

Estas unidades hidrográficas, juntamente com o lago, formam a bacia do Lago Paranoá. O Lago abrange as Regiões Administrativas (RA's) de Brasília, Lago Sul, Lago Norte, Cruzeiro, Núcleo Bandeirante, Candangolândia, Riacho Fundo, Guará, parte de Taguatinga e a área urbana do Paranoá (ADASA, 2012), e ocupa, por sua vez, cerca de 5\% da bacia (DISTRITO FEDERAL, 2005). 


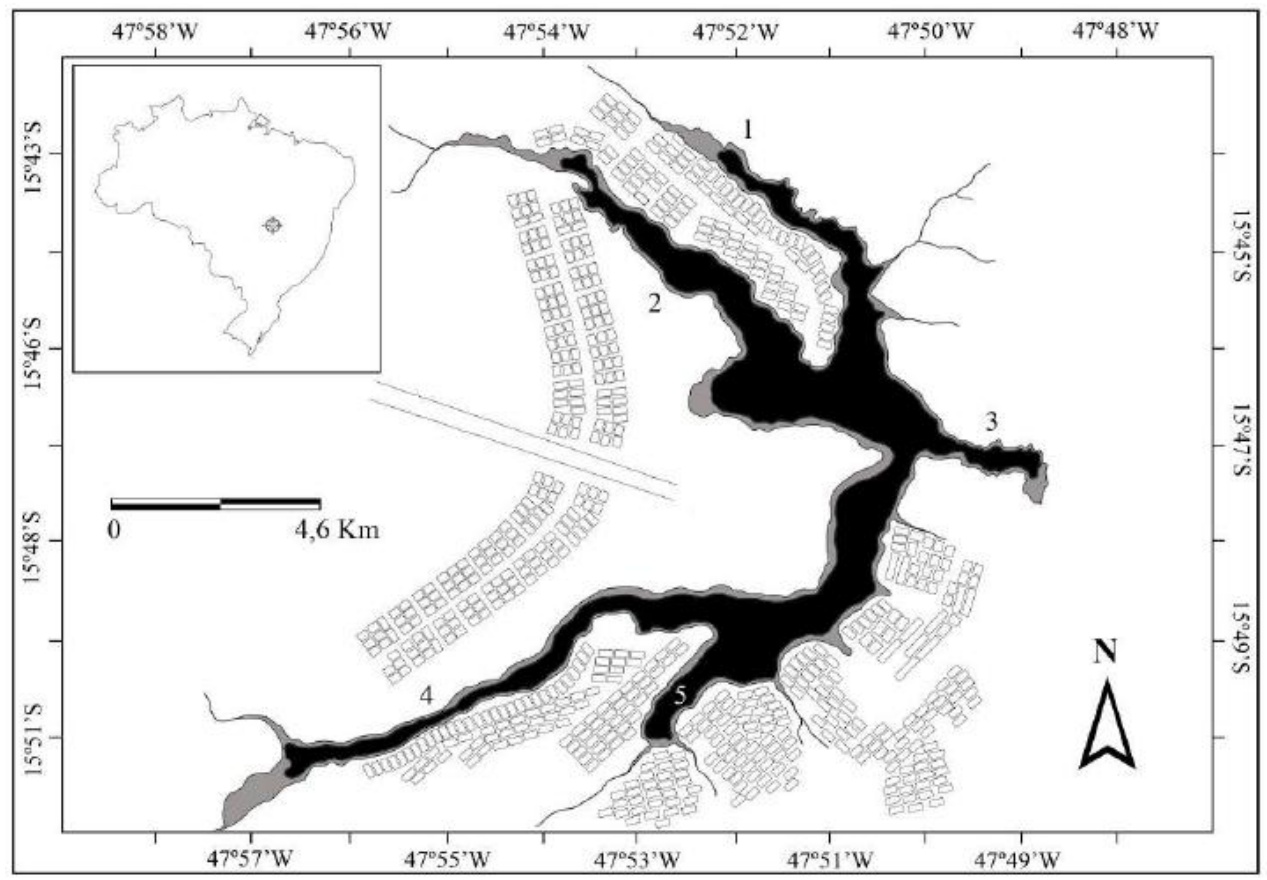

Figura 4.2 - Mapa do lago Paranoá - DF.

1 - Braço do Ribeirão do Torto; 2 - Braço do Bananal; 3 - Região Central (Braço do Paranoá); 4 - Braço do Riacho Fundo; 5 - Braço do Gama Fonte: Corrêa (2011)

O lago Paranoá foi criado com o intuito de fornecer energia elétrica, aumentar a umidade, garantir lazer e turismo, para a população de Brasília. Também é utilizado para diluir os efluentes sanitários, receber as águas pluviais, e para a pesca, além de sua utilização, em breve, para captação de água com a finalidade de abastecimento público (ADASA, 2011; BARROS, 2010; ECHEVERRIA, 2007; FONSECA, 2001).

Segundo a Companhia de Saneamento Ambiental do Distrito Federal - CAESB (2005), os esgotos sanitários de Brasília são coletados e transportados para duas estações de tratamento de esgotos (ETE) com tratamento terciário, denominadas ETE Brasília Norte (atende ao Lago Norte e parte do Plano Piloto) e ETE Brasília Sul (atende ao Guará, Cruzeiro, Núcleo Bandeirante, Candangolândia, Lago Sul, parte de Brasília e a quadra QN1 do Riacho Fundo) que descarregam seus efluentes próximos do início de dois braços do lago, os braços do Ribeirão Bananal e do Riacho Fundo (ADASA, 2012).

O Lago situa-se na região urbana de Brasília entre os paralelos $15^{\circ} 45^{\prime} \mathrm{S}$ e $47^{\circ} 47^{\prime}$ W. Possui profundidade média de $12,4 \mathrm{~m}$ e volume de 498,6 × $10^{6} \mathrm{~m}^{3}$. O clima da região é caracterizado como tropical de savana, de acordo com a classificação de Köppen, apresentando duas estações bem características: uma seca e fria correspondendo ao inverno (de maio a setembro) e outra quente e chuvosa (outubro a abril) no verão (FONSECA, 2001). 
A temperatura média de suas águas está entre 19 e $22^{\circ} \mathrm{C}$ e a transparência varia entre 0 a 5 metros na profundidade da coluna d'água (BARROS, 2010). As características do lago podem ser observadas na Tabela 4.1.

Tabela 4.1 - Caracterização do lago Paranoá

\begin{tabular}{lclc}
\hline Bacia de Drenagem & $1.034,07 \mathrm{~km}^{2}$ & Perímetro & $111,87 \mathrm{~km}$ \\
\hline Área Superficial & $37,5 \mathrm{~km}^{2}$ & Comprimento & $40 \mathrm{~km}$ \\
\hline Volume Total & $498 \times 10^{6} \mathrm{~m}^{3}$ & Largura Máxima & $5 \mathrm{~km}$ \\
\hline Profundidade Média & $12,42 \mathrm{~m}$ & Tempo de Retenção & 299 dias \\
\hline Profundidade Máxima & $40,00 \mathrm{~m}$ & & \\
& & & \\
\hline
\end{tabular}

Fonte: Fonseca (2001)

A recarga do lago é formada pelas águas dos seus tributários, águas de drenagens pluviais urbanas, e efluentes das Estações de Tratamento de Esgotos (ETE Brasília Sul e ETE Brasília Norte), as quais usam o lago Paranoá como corpo hídrico receptor; bem como a precipitação direta sobre sua superfície. Também chegam até o lago, através dos tributários, os efluentes de outras estações de tratamento de esgotos situadas na sua bacia de drenagem, a saber: ETE Riacho Fundo, cujo corpo hídrico receptor é o Riacho Fundo, e ETE Torto (PARENTE, 2006).

Em novembro de 1978, foi registrado o evento mais crítico no lago Paranoá, causado por uma floração de cianobactérias, atribuída à elevada disponibilidade de nutrientes (fósforo e nitrogênio), em decorrência do lançamento de esgotos sanitários inadequadamente tratados naquela época. A floração foi formada pela espécie Microcystis aeruginosa, tendo havido elevada produção de mau cheiro e mortandade de peixes. A solução rápida e efetiva para acabar com a floração de Microcystis aeruginosa foi a adição do algicida sulfato de cobre (BURNETT; MATTOS; AZZOLIN, 2001; PINTO; CAVALCANTI; LUDUVICE, 1999). Outros episódios de florações ainda foram observados principalmente no braço do Riacho Fundo, porção sul do reservatório (BURNETT; MATTOS; AZZOLIN, 2001; PADOVESI-FONSECA; PHILOMENO, 2004).

Após os episódios de florações, a Companhia de Saneamento Ambiental do Distrito Federal - CAESB - iniciou um programa de monitoramento, com o objetivo de melhorar e manter a qualidade da água do reservatório. O tratamento terciário do esgoto, com início das operações das ETE em 01/1993, passou a ser realizado e mostrou que o controle do 
fósforo é condição essencial para a diminuição da produtividade primária no reservatório associado ao flushing que aumentou a transparência da água, reduzindo os valores de clorofila-a e fósforo total (ANGELINI; BINI; ATARLING, 2008). O resultado do processo de controle da eutrofização foi a redução da biomassa algal (em média 90\%), identificada como desencadeadora de diversos episódios de mortandade de peixes (STARLING, 2010).

Devido à utilização, futura, do lago Paranoá para abastecimento público, o monitoramento da qualidade da água é fundamental. As cinco estações de monitoramento do lago (A e B porção Sul; C corpo central; D e E porção Norte do Lago) operadas pela ADASA - Agência Reguladora de Águas, Energia e Saneamento Básico do Distrito Federal apresentaram resultados satisfatórios, o que não acarretam em prejuízos aos usos da água (ADASA, 2012). A qualidade da água e a localização do lago, além do aumento na densidade populacional, justificam a captação, que será realizada na porção central do Lago próximo ao ponto C (Figura 4.3) (CAESB, 2011b).

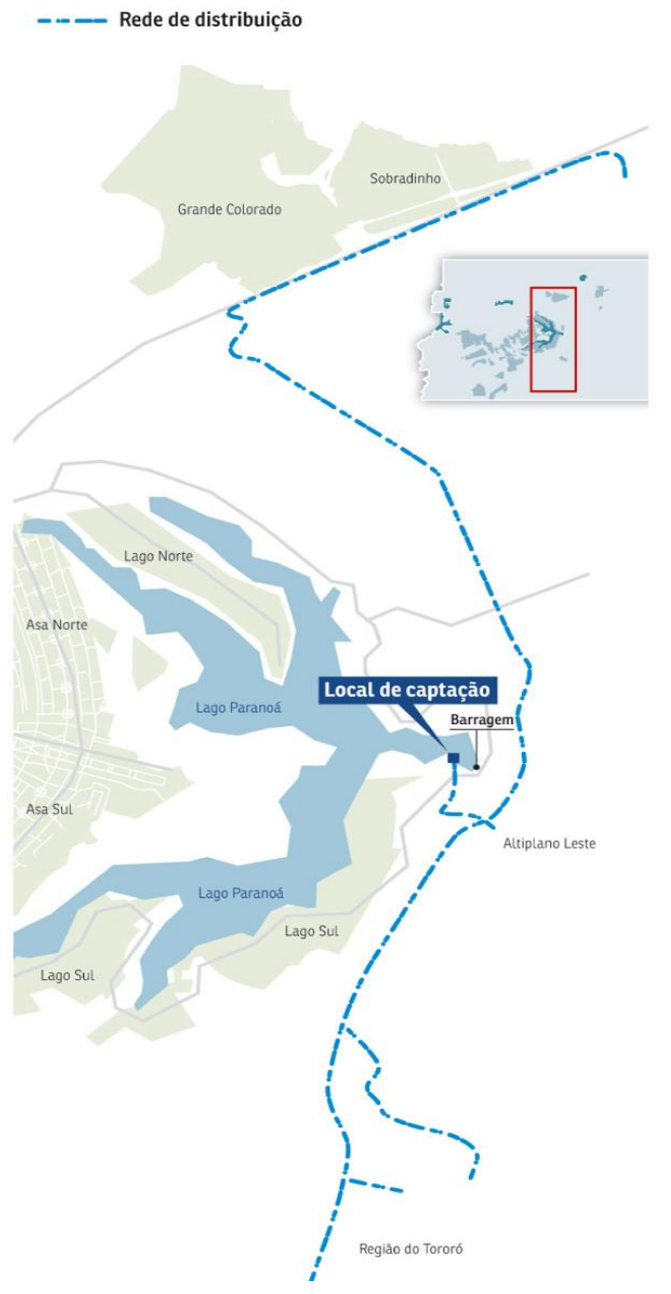

Figura 4.3 - Ponto de captação de água no lago Paranoá Disponível em: Adasa (2011b) 
Assim, dentre os diversos parâmetros avaliados continuamente no lago Paranoá, pelos órgãos competentes, para garantir os usos múltiplos desse reservatório, a avaliação do fitoplâncton, o que inclui o monitoramento de cianobactérias potencialmente tóxicas e seus compostos, são fundamentais para a avalição da qualidade da água nesse manancial, que em breve será utilizado como fonte para abastecimento público.

\subsection{Amostragem}

O trabalho foi realizado com amostras de água previamente coletadas em diferentes pontos no lago Paranoá, entre os anos de 2012 e 2014, parte do monitoramento realizado no âmbito dos projetos de pesquisa do Programa de Pós-Graduação em Tecnologia Ambiental e Recursos Hídricos, PTARH, ENC/FT/UnB.

As amostras foram coletadas mensalmente em 07 diferentes estações denominadas: A e B (localizadas na porção Sul do lago), C (Barragem), D e E (porção Norte), G e H (corpo central do lago), conforme descrito na Figura 4.4. As amostras utilizadas no presente estudo foram coletadas na profundidade de extinção do disco de Secchi (correspondente a $10 \%$ de incidência de luz na coluna d'água).

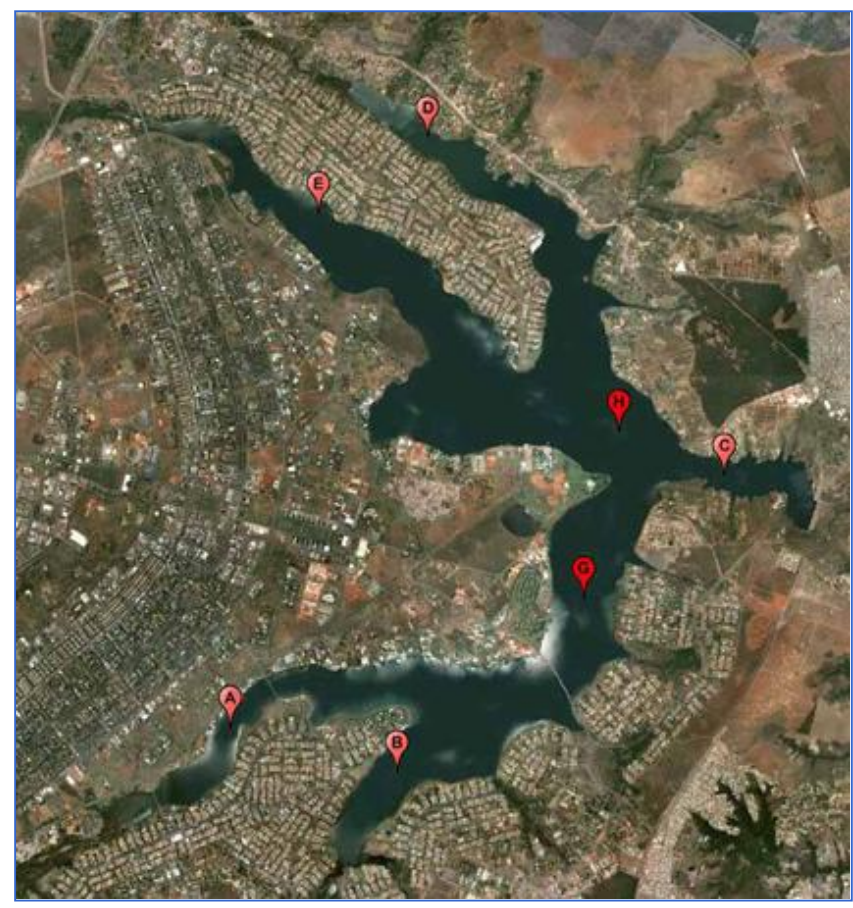

Figura 4.4 - Localização dos pontos de coleta de amostras no lago Paranoá Fonte: Google Earth, 2015 
No laboratório, as amostras de água coletadas no lago Paranoá foram filtradas utilizando-se o sistema de filtração a vácuo seguindo os seguintes procedimentos:

a) Foram preparados envelopes de papel alumínio, contendo informações como: $\mathrm{n}^{\circ}$ da amostra, local, $\mathrm{pH}$, data da coleta e da filtração;

b) As amostras foram cuidadosamente homogeneizadas e um volume de 01 litro, medido em uma proveta graduada foi filtrado, utilizando filtro analítico AP 40 em microfibra de vidro, sem resina, com $47 \mathrm{~mm}$ de diâmetro e porosidade de $0,45 \mu \mathrm{m}$ (Millipore);

c) Terminada a filtração das amostras, o filtro foi retirado cuidadosamente com uma pinça, evitando o contato com as mãos. O filtro foi dobrado ao meio, deixando o material filtrado do lado interno da dobra. O filtro foi guardado no envelope de papel alumínio previamente identificado;

d) Os envelopes contendo os filtros utilizados foram mantidos no freezer em temperatura igual ou inferior a $-20{ }^{\circ} \mathrm{C}$ e superior a $-30{ }^{\circ} \mathrm{C}$;

e) Após a filtração, foram registrados (formulários em papel e sistema eletrônico) o volume filtrado e informações relevantes da amostra como $\mathrm{n}^{\mathrm{o}}$ da amostra, data e local de coleta, pH e data da filtragem (mesmas informações do envelope) (BRANDÃO et al., 2011; CETESB, 2014).

f) Os filtros devidamente armazenados foram utilizados para extração de DNA genômico conforme protocolo descrito a seguir.

\subsection{Extração de DNA genômico}

Para a extração do DNA, foi utilizado inicialmente, meio filtro para obtenção do material genômico do séston. O protocolo de extração seguiu o proposto por Neilan et al. (2002). O primeiro passo consistiu na adição de $500 \mu \mathrm{L}$ do tampão XS (1\% de potássiometilxantogenato; $800 \mathrm{mM}$ de acetato de amônio - $\mathrm{NH}_{4} \mathrm{OAc} ; 20 \mathrm{mM}$ EDTA; $1 \%$ SDS; 100 $\mathrm{mM}$ Tris-HCL, pH 7,4) à metade do filtro. Esse material foi incubado, am banho-maria, a $65^{\circ} \mathrm{C}$ por duas horas (agitando em vórtex após uma hora).

A solução foi então colocada em banho de gelo por 10 minutos e em seguida centrifugada a $14.000 \mathrm{~g}$ por 20 minutos. O sobrenadante foi recolhido em tubos eppendorfs limpos e foi feita a extração do DNA utilizando o tampão TNE - adicionou-se $500 \mu \mathrm{L}$ de fenol/clorofórmio/álcool isoamil (25:24:1) e centrifugou-se a 12000 g por 05 minutos. Repetiu-se esse procedimento uma vez. 
Após essa fase, o sobrenadante foi recolhido e o DNA presente foi precipitado com a adição de uma solução de isopropanol (1 volume) e acetato de potássio (KOAc) $4 \mathrm{M}$ (1/10 de volume) e colocado na geladeira a $4^{\circ} \mathrm{C}$ por 15 minutos, seguido de centrifugação a $12.000 \mathrm{~g}$ por 20 minutos. O DNA já extraído foi então lavado com $1 \mathrm{~mL}$ de etanol $70 \%$ e novamente centrifugado a $12.000 \mathrm{~g}$ por 15 minutos. Após o descarte do sobrenadante e evaporação do etanol o DNA foi ressuspendido em $50 \mu \mathrm{L}$ de água deionizada.

Dentre as amostras de água, coletadas no lago Paranoá no período de 2012 a 2014, foram selecionados os meses de janeiro, junho, julho, agosto, novembro e dezembro, e um total de 36 amostras de água foram utilizadas para a extração do material genômico (Quadro 4.1). O DNA extraído foi congelado e posteriormente preparado para a amplificação de sequências específicas do DNA de cianobactérias, por meio de reações de PCR.

Quadro 4.1 - Períodos e pontos selecionados para coleta das amostras

\begin{tabular}{|c|l|l|}
\hline Ano de coleta & Meses de coleta & Pontos/estações de coleta \\
\hline \multirow{2}{*}{2012} & Agosto & $\mathrm{A}, \mathrm{B}, \mathrm{C}, \mathrm{D}, \mathrm{E}, \mathrm{G}, \mathrm{H}$ \\
\cline { 2 - 3 } & Novembro & $\mathrm{A}, \mathrm{C}, \mathrm{E}$ \\
\cline { 2 - 3 } & Dezembro & $\mathrm{A}, \mathrm{B}, \mathrm{H}$ \\
\hline \multirow{2}{*}{2013} & Janeiro & $\mathrm{A}, \mathrm{B}, \mathrm{C}, \mathrm{D}, \mathrm{E}, \mathrm{H}$ \\
\cline { 2 - 3 } & Junho & $\mathrm{A}, \mathrm{B}, \mathrm{C}, \mathrm{D}, \mathrm{E}, \mathrm{G}$ \\
\hline \multirow{2}{*}{2014} & Janeiro & $\mathrm{C}, \mathrm{D}, \mathrm{E}, \mathrm{H}$ \\
\cline { 2 - 3 } & Julho & $\mathrm{A}, \mathrm{B}, \mathrm{C}, \mathrm{D}, \mathrm{E}, \mathrm{G}, \mathrm{H}$ \\
\hline
\end{tabular}

Fonte: Elaborado pela autora

O Quadro 4.2 descreve os pontos de referência onde localizam-se as estações de coleta das amostras de água no lago Paranoá.

Quadro 4.2 - Pontos de referência das estações de coleta das amostras no lago Paranoá

\begin{tabular}{|c|l|}
\hline Estações & \multicolumn{1}{c|}{ Referência } \\
\hline A & Setor de clubes Sul (próximo a ETE Sul) \\
\hline B & Península dos ministros \\
\hline C & Ermida Dom Bosco (barragem) \\
\hline D & Próximo a rede Sarah \\
\hline E & Ponte do Bragueto (próximo a ETE Norte) \\
\hline G & Clube de golfe (Corpo central do lago) \\
\hline H & Palácio da Alvorada (Corpo central do lago) \\
\hline
\end{tabular}

Fonte: Elaborado pela autora

A extração de DNA foi também efetuada com a amostra utilizada como controle nas reações de PCR. A amostra controle foi oriunda da cianobactéria - Microcystis NPLJ-4 - 
cultivada no Laboratório de Saneamento Ambiental, do Departamento de Engenharia Civil e Ambiental da UnB.

\subsection{Amplificações usando PCR convencional}

Para a realização das amplificações das sequências do DNA alvo foi empregada a técnica de amplificação in vitro, reação em cadeia da polimerase (Polymerase Chain Reaction - PCR), utilizando oligonucleotídeos iniciadores, específicos para a detecção tanto dos genes relacionados à produção de toxinas, quanto da porção $16 \mathrm{~S}$ do DNAr e do operon da ficocianina de cianobactérias.

A escolha dos iniciadores, específicos para a detecção dos genes relacionados à produção de cianotoxinas, foi feita com base nas análises qualitativas do fitoplâncton das amostras de água. Os estudos qualitativos do fitoplâncton, realizados no Laboratório de Saneamento Ambiental (LSA) do Departamento de Engenharia Civil e Ambiental da Universidade de Brasília, demonstram até o momento o predomínio de cianobactérias potencialmente produtoras de microcistinas, como os gêneros Aphanocapsa, Aphanothece e Microcystis (não publicado). Dessa forma, os iniciadores utilizados na pesquisa foram àqueles relacionados aos genes da síntese de microcistinas (mcyA-J). Todos os oligonucleotídeos utilizados estão descritos no Quadro 4.3.

Quadro 4.3 - Relação dos iniciadores oligonucleotídicos usados para a amplificação de porções distintas do genoma de cianobactérias: DNA 16S, operon da ficocianina, síntese de microcistinas

\begin{tabular}{|c|c|c|c|c|}
\hline Denominação & Sequências $^{\mathrm{a}}$ & Genes alvo & $\mathbf{T}_{\mathrm{A}}\left({ }^{\circ} \mathbf{C}\right)^{\mathbf{b}}$ & Referências \\
\hline $\begin{array}{c}27 F \\
809 R\end{array}$ & $\begin{array}{l}\text { AGAGTTTGATCCTGGCTCAG } \\
\text { GCTTCGGCACGGCTCGGGTCGATA }\end{array}$ & 16S Rrna & 55 & $\begin{array}{l}\text { Salmon e Neilan (não } \\
\text { publicado) } \\
\text { Jungblut et al. (2005) }\end{array}$ \\
\hline $\begin{array}{l}\text { PC } \beta F \\
\text { PC } \alpha R\end{array}$ & $\begin{array}{l}\text { GGCTGCTTGTTTACGCGACA } \\
\text { CCAGTACCACCAGCAACTAA }\end{array}$ & Ficocianina & 55 & Neilan et al. (1995) \\
\hline $\begin{array}{l}\text { FAA } \\
\text { RAA }\end{array}$ & $\begin{array}{l}\text { CTATGTTATTTATACATCAGG } \\
\text { CTCAGCTTAACTTGATTATC }\end{array}$ & $M c y B$ & 50 & Neilan et al. (1999) \\
\hline $\begin{array}{l}\text { mcyDF } \\
\text { mcyDR }\end{array}$ & $\begin{array}{l}\text { GGTTCGCCTGGTCAAAGTAA } \\
\text { CCTCGCTAAAGAAGGGTTGA }\end{array}$ & $M c y \mathrm{D}$ & 55 & $\begin{array}{l}\text { Rinta-Kanto et al. (2005) } \\
\text { Hotto et al. }(2008) \\
\text { Kaebernick et al. }(2000)\end{array}$ \\
\hline
\end{tabular}

\footnotetext{
'a Sequências oligonucleotídicas dadas na orientação 5' - 3'.

b Temperatura de anelamento dos iniciadores.

Fonte: Elaborado pela autora
} 
O protocolo padrão para a realização da PCR foi volume de reação definido de 20 $\mu \mathrm{L}$, sendo $19 \mu \mathrm{L}$ da solução de reagentes e $1 \mu \mathrm{L}$ da amostra de DNA genômico extraído (a partir da diluição de 1:10), na primeira etapa da metodologia, e pronto para ser amplificado. A reação foi feita em solução contendo: $0,2 \mu \mathrm{L}$ da enzima Taq DNA polimerase (Invitrogen), 1 $\mu \mathrm{L}$ de cloreto de magnésio $\left(\mathrm{MgCl}_{2}\right)$ 2,5 mM, $2 \mu \mathrm{L}$ de tampão para reação PCR 10X, $2 \mu \mathrm{L}$ de dNTPs (dATP, dTTP, dCTP, dGTP) 0,2 mM (Invitrogen), 0,5 pmol de cada iniciador (1 $\mu \mathrm{L}) \mathrm{e}$ água ultra pura esterilizada suficiente para um volume final de $19 \mu \mathrm{L}$.

A reação ocorreu em um termociclador MJ Mini Thermal Cycler (Bio Rad).

A região $27 \mathrm{~F} / 809 \mathrm{R}$ do gene $16 \mathrm{~S}$ do DNA ribossomal foi amplificada, com os oligonucleotídeos descritos no Quadro 4.3, gerando um fragmento de aproximadamente 800 pb. O ciclo da reação consistiu em uma fase inicial de desnaturação a $94{ }^{\circ} \mathrm{C}$ por 4 minutos, seguido por 30 ciclos de: $94{ }^{\circ} \mathrm{C}$ por 20 segundos, $55^{\circ} \mathrm{C}$ por 30 segundos e $72{ }^{\circ} \mathrm{C}$ por 1 minuto. Em seguida a extensão final ocorreu em um passo de 7 minutos a $72{ }^{\circ} \mathrm{C}$.

Um protocolo adicional foi utilizado para amplificar a região 27F/809R do gene 16S do DNA ribossomal consistindo em: desnaturação a $94{ }^{\circ} \mathrm{C}$ por 2 minutos, seguido por 35 ciclos de $94{ }^{\circ} \mathrm{C}$ por 20 segundos, $54{ }^{\circ} \mathrm{C}$ por 1 minuto e $65^{\circ} \mathrm{C}$ por 5 minutos. A extensão final ocorreu a $65{ }^{\circ} \mathrm{C}$ por 10 minutos. Esse protocolo utilizou a enzima Long Amp Taq DNA polimerase (Ludwig Biotec).

A região $\mathrm{PC} \beta \mathrm{F} / \mathrm{PC} \alpha \mathrm{R}$ do pigmento ficocianina foi amplificada, por meio dos oligonucleotídeos descritos no Quadro 4.3, gerando um fragmento de aproximadamente 685 pb. O ciclo da reação consistiu em uma fase inicial de desnaturação a $94{ }^{\circ} \mathrm{C}$ por 2 minutos, seguido por 40 ciclos de: $94{ }^{\circ} \mathrm{C}$ por 20 segundos, $55^{\circ} \mathrm{C}$ por 30 segundos e $72{ }^{\circ} \mathrm{C}$ por 1 minuto. Em seguida a extensão final a $72{ }^{\circ} \mathrm{C}$ por 7 minutos.

A região FAA/RAA do gene $m c y \mathrm{~B}$ foi amplificada, por meio dos oligonucleotídeos descritos no Quadro 4.3, gerando um fragmento de aproximadamente 758 pb. O ciclo da reação consistiu em uma fase inicial de desnaturação a $94{ }^{\circ} \mathrm{C}$ por 2 minutos, seguido por 35 ciclos de: $93{ }^{\circ} \mathrm{C}$ por 10 segundos, $50{ }^{\circ} \mathrm{C}$ por 20 segundos e $72{ }^{\circ} \mathrm{C}$ por 1 minuto, e extensão final a $72{ }^{\circ} \mathrm{C}$ por 7 minutos.

A região mcyDF/mcyDR do gene $m c y \mathrm{D}$ foi amplificada, por meio dos oligonucleotídeos descritos no Quadro 4.3, gerando um fragmento de aproximadamente 297 pb. O ciclo da reação consistiu em uma fase inicial de desnaturação a $94{ }^{\circ} \mathrm{C}$ por 4 minutos, seguido por 35 ciclos de: $94{ }^{\circ} \mathrm{C}$ por 30 segundos, $42^{\circ} \mathrm{C}$ por 30 segundos e $72{ }^{\circ} \mathrm{C}$ por 1 minuto, e extensão final a $72{ }^{\circ} \mathrm{C}$ por 7 minutos. 
Os produtos da reação foram analisados em eletroforese em gel de agarose (1\%) em solução tampão TBE $1 \mathrm{X}$ e corados em solução de brometo de etídio $(1 \mu \mathrm{g} / \mathrm{mL})$ por 10 minutos. Para a documentação fotográfica e visualização do gel foi utilizado um transluminador UV GelDoc EZ Imager (BioRad) e o programa de computador Image Lab Software (versão 5.2.1) (BioRad). De forma geral, foram aplicados $4 \mu \mathrm{L}$ de amostra (produtos de PCR) e $2 \mu \mathrm{L}$ de tampão de carregamento (loading buffer) em cada gel de agarose, para visualização das bandas.

\subsection{Sequenciamento dos produtos da PCR}

Os produtos obtidos após as reações de amplificação (PCR) foram enviados para serem sequenciados pela empresa Macrogen (Coreia do Sul) e pela Universidade Católica de Brasília (UCB) usando o método de Sanger. As sequências enviadas pela Macrogen e pela UCB foram, então, analisadas utilizando-se o programa de computador Applied Biosystem Auto-Assembler e conferidas manualmente quanto à sua qualidade. A identidade de cada sequência foi determinada através da homologia com as sequências publicadas no banco internacional de genes - GenBank (http://www.ncbi.nih.gov/Genbank), utilizando-se a Ferramenta Básica de Busca de Alinhamento Local - BLAST (do inglês, Basic Local Aligment Search Tool), disponibilizado na internet pelo Instituto Nacional de Saúde (National Institutes of Health) (http://www.ncbi.nlm.nih.gov/BLAST).

\subsection{Teste de ELISA}

A presença e quantificação de cianotoxinas nas amostras foram medidas por meio da utilização de kit do teste de ELISA (Enzyme-linked immunosorbent assay) - Microcystins ELISA (Abraxis) utilizando a metade do filtro que não foi utilizado no processo de extração de DNA conforme item 4.3. As amostras coletadas em 2013 e 2014, descritas nos Quadros 4.1 e 4.2, foram selecionadas para quantificação de cianotoxinas. Adicionou-se $1,5 \mathrm{~mL}$ de metanol a cada amostra. Essa mistura foi mantida em temperatura ambiente por duas horas. Em seguida, os tubos foram centrifugados a $12000 \mathrm{~g}$ por 15 minutos. O sobrenadante foi coletado e armazenados em tubos eppendorfs limpos. A solução contida nos tubos foi evaporada e concentrada em speed vac (Eppendorf), e ressuspendida em $500 \mu \mathrm{L}$ de água deionizada. A solução final foi então utilizada para realização do teste, conforme orientações do fabricante. 


\section{RESULTADOS E DISCUSSÃO}

\subsection{Perfil genético e investigação da toxicidade das cianobactérias}

Os resultados referentes ao perfil genético das cianobactérias presentes em amostras de água, coletadas no lago Paranoá, são apresentados a seguir contendo a caracterização molecular, a avaliação do potencial de biossíntese de toxinas e da toxicidade das amostras.

\subsubsection{Caracterização molecular}

As amostras utilizadas no estudo, coletadas na profundidade de extinção do disco de Secchi, cujas estações de coleta estão descritas no Quadro 4.1, detectaram a presença de cianobactérias por meio da amplificação do fragmento da porção $16 \mathrm{~S}$ DNAr, usando os iniciadores 27F/809R, com exceção das amostras coletadas em novembro de 2012, nos pontos A e C, e a amostra de junho de 2013, coletada no ponto A. Os resultados dos ensaios de PCR podem ser visualizados no Quadro 5.1. As imagens dos géis de agarose resultantes das amplificações do 16S DNAr podem ser observadas no Apêndice 1.

Dados sobre o percentual de ocorrência de cianobactérias, resultantes do monitoramento mensal do fitoplâncton do lago Paranoá realizado pela CAESB, que analisa amostras coletadas a $1 \mathrm{~m}$ da superfície, foram utilizados com o intuito de comparar os resultados obtidos nos testes de PCR e as cianobactérias identificadas e quantificadas no Lago, por microscopia. Os resultados estão disponíveis no Quadro 5.1. É importante ressaltar que a CAESB não realiza monitoramento nos pontos $\mathrm{G}$ e $\mathrm{H}$ e que esses dados não correspondem, necessariamente, ao mesmo dia de coleta das amostras utilizadas nos ensaios da PCR, mas são úteis para que se possa ter uma ideia do percentual de ocorrência das cianobactérias em relação ao valor total do fitoplâncton no Lago.

Quadro 5.1 - Resultados dos ensaios de PCR usando os iniciadores da porção do 16 S do DNAr, das porções cpcA e cpcB, incluindo o espaço intergênico (cpcBA-IGS), do operon da ficocianina e percentual de cianobactérias (indivíduo/mL)

\begin{tabular}{|c|c|c|c|c|}
\hline Período de coleta & Amostras & 27F/809R & PC $\beta F / P C \alpha R$ & Percentual de ocorrência de cianobactérias \\
\hline \multirow{6}{*}{ Agosto de 2012} & $\mathrm{~A}$ & + & - & Aphanocapsa $\operatorname{spp}(1,2 \%)$ \\
\hline & B & + & - & $\begin{array}{l}\text { Aphanocapsa spp (12\%) } \\
\text { Cyanodictyon } \mathrm{sp}(5 \%)\end{array}$ \\
\hline & $\mathrm{C}$ & + & - & $\begin{array}{l}\text { Aphanocapsa spp (11\%) } \\
\text { Cyanodictyon sp (3\%) }\end{array}$ \\
\hline & $\mathrm{D}$ & + & - & $\begin{array}{l}\text { Aphanocapsa spp (19\%) } \\
\text { Cyanodictyon sp (1\%) }\end{array}$ \\
\hline & $\mathrm{E}$ & + & - & $\begin{array}{l}\text { Aphanocapsa spp (8\%) } \\
\text { Cyanodictyon } \mathrm{sp}(1 \%)\end{array}$ \\
\hline & G & + & - & Não realizado \\
\hline
\end{tabular}




\begin{tabular}{|c|c|c|c|c|}
\hline Período de coleta & Amostras & 27F/809R & PC $\beta F / P C \alpha R$ & Percentual de ocorrência de cianobactérias \\
\hline & $\mathrm{H}$ & + & - & Não realizado \\
\hline \multirow{3}{*}{ Novembro de 2012} & A & - & - & Sem dado \\
\hline & $\mathrm{C}$ & - & - & Sem dado \\
\hline & $\mathrm{E}$ & + & - & Sem dado \\
\hline \multirow{3}{*}{ Dezembro de 2012} & A & + & - & Sem dado \\
\hline & $\mathrm{B}$ & + & - & Sem dado \\
\hline & $\mathrm{H}$ & + & - & Não realizado \\
\hline \multirow{6}{*}{ Janeiro de 2013} & A & + & - & $\begin{array}{l}\text { Aphanocapsa spp (34\%) } \\
\text { Cyanodictyon sp (2\%) }\end{array}$ \\
\hline & B & + & - & $\begin{array}{l}\text { Aphanocapsa spp (70\%) } \\
\text { Cyanodictyon } \mathrm{sp}(2 \%)\end{array}$ \\
\hline & $\mathrm{C}$ & + & + & $\begin{array}{l}\text { Aphanocapsa spp (89\%) } \\
\text { Cyanodictyon sp (2\%) }\end{array}$ \\
\hline & $\mathrm{D}$ & + & - & $\begin{array}{l}\text { Aphanocapsa spp (91\%) } \\
\text { Cyanodictyon } \mathrm{sp}(2 \%)\end{array}$ \\
\hline & $\mathrm{E}$ & + & - & $\begin{array}{l}\text { Aphanocapsa spp }(90 \%) \\
\text { Cyanodictyon } \mathrm{sp}(0,4 \%)\end{array}$ \\
\hline & $\mathrm{H}$ & + & + & Não realizado \\
\hline \multirow{6}{*}{ Junho de 2013} & A & - & - & $\begin{array}{c}\text { Aphanocapsa spp }(30 \%) \\
\text { Cyanodictyon } \mathrm{sp}(0,4 \%) \\
\text { Planktolyngbya limnetica }(0,7 \%)\end{array}$ \\
\hline & B & + & + & $\begin{array}{l}\text { Aphanocapsa } \operatorname{spp}(73 \%) \\
\text { Cyanodictyon } \mathrm{sp}(0,5 \%)\end{array}$ \\
\hline & $\mathrm{C}$ & + & - & $\begin{array}{c}\text { Aphanocapsa spp }(81 \%) \\
\text { Cyanodictyon } \mathrm{sp}(0,6 \%) \\
\text { Planktolyngbya limnetica }(2 \%)\end{array}$ \\
\hline & $\mathrm{D}$ & + & - & $\begin{array}{c}\text { Aphanocapsa spp }(72 \%) \\
\text { Cyanodictyon } \mathrm{sp}(0,5 \%) \\
\text { Planktolyngbya limnetica }(1 \%)\end{array}$ \\
\hline & $\bar{E}$ & + & - & $\begin{array}{c}\text { Aphanocapsa spp }(77 \%) \\
\text { Cyanodictyon } \mathrm{sp}(0,4 \%) \\
\text { Planktolyngbya limnetica }(0,4 \%)\end{array}$ \\
\hline & $\mathrm{G}$ & + & - & Não realizado \\
\hline \multirow[t]{4}{*}{ Janeiro de 2014} & $\mathrm{C}$ & + & + & $\begin{array}{c}\text { Aphanocapsa } \mathrm{spp}(60 \%) \\
\text { Cyanodictyon } \mathrm{sp}(2,6 \%) \\
\text { Epigloeosphaera }(3 \%) \\
\text { Planktolyngbya limnetica }(22 \%)\end{array}$ \\
\hline & $\mathrm{D}$ & + & - & $\begin{array}{c}\text { Aphanocapsa } \mathrm{spp}(47 \%) \\
\text { Cyanodictyon } \mathrm{sp}(0,8 \%) \\
\text { Epigloeosphaera }(1 \%) \\
\text { Planktolyngbya limnetica }(44 \%)\end{array}$ \\
\hline & $\mathrm{E}$ & + & + & $\begin{array}{c}\text { Aphanocapsa } \operatorname{spp}(62 \%) \\
\text { Cyanodictyon } \operatorname{sp~}(2 \%) \\
\text { Epigloeosphaera }(1 \%) \\
\text { Planktolyngbya limnetica }(17 \%)\end{array}$ \\
\hline & $\mathrm{H}$ & + & - & Não realizado \\
\hline \multirow{7}{*}{ Julho de 2014} & $\mathrm{~A}$ & + & - & Sem dado \\
\hline & $\mathrm{B}$ & + & - & Sem dado \\
\hline & $\mathrm{C}$ & + & - & Sem dado \\
\hline & $\mathrm{D}$ & + & - & Sem dado \\
\hline & $\mathrm{E}$ & + & - & Sem dado \\
\hline & $\mathrm{G}$ & + & - & Não realizado \\
\hline & $\mathrm{H}$ & + & - & Não realizado \\
\hline
\end{tabular}

(+) presença e (-) ausência de produtos de amplificação por PCR confirmado pela presença de banda em gel de agarose Fonte: Elaborado pela autora

O mês de novembro de 2012 (Quadro 5.1) enquadra-se no período chuvoso, sendo mês de verão, com temperaturas mais elevadas e de estratificação térmica da coluna d'água, e essas características favorecem o desenvolvimento das cianobactérias. A ausência de amplificação da porção do gene $16 \mathrm{~S}$ DNAr, provavelmente, está relacionada com a presença de inibidores das reações de PCR ou possivelmente relacionada com a qualidade do DNA alvo presente no DNA genômico. Na Figura 5.1 pode-se observar o gel de agarose contendo o DNA genômico extraído a partir de amostras coletadas em agosto de 2012 e janeiro de 2013. 
De acordo com o percentual de ocorrência de cianobactérias no lago Paranoá, de modo geral, as cianobactérias foram detectadas com baixas densidades, quando comparado com a densidade do fitoplâncton total, com exceção do gênero Aphanocapsa spp. (picoplâncton), que destacou-se por apresentar percentual de ocorrência elevado nos períodos de janeiro de 2013, janeiro de 2014 e junho de 2013, nas estações de coleta (Quadro 5.1).

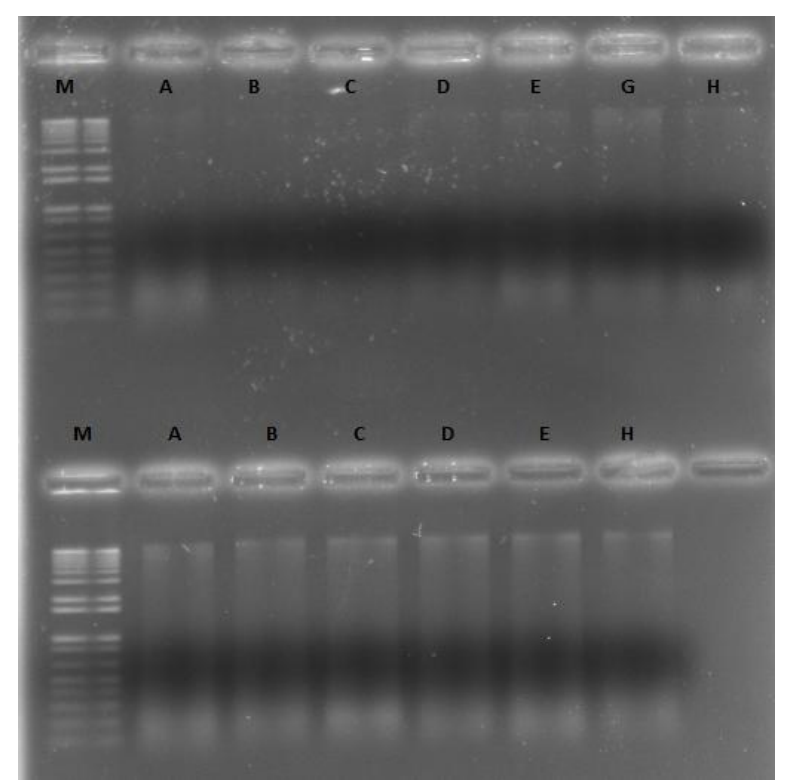

Figura 5.1 - Imagem do gel de agarose contendo o DNA genômico extraído de amostras coletadas em agosto de 2012 (parte superior do gel) e em janeiro de 2013 (parte inferior do gel)

Fonte: Elaborado pela autora

O percentual pequeno de ocorrência de cianobactérias provavelmente refletiu na qualidade do DNA alvo presente no material genômico do fitoplâncton, obtido por meio da extração e utilizado nos testes da PCR. Paabo, Irwin e Wilson (1990) afirmam que se amplificações são iniciadas com poucas moléculas molde (DNA alvo), danos na molécula molde podem refletir nos produtos de amplificação.

Souza (2013) avaliou a utilização de índices de integridade biótica do fitoplâncton, como ferramenta para a estimativa da qualidade da água do lago Paranoá, e para isso, utilizou os dados de monitoramento realizado pela CAESB, o que inclui os valores de clorofila $a$, densidade celular e biomassa do fitoplâncton no período de 1999 a 2011, descritos na Tabela 5.1. Esses parâmetros apresentaram valores médios baixos, o que confirma o percentual pequeno do fitoplâncton no lago ao longo dos anos. 
Tabela 5.1 - Valores médios de clorofila a $(\mu \mathrm{g} / \mathrm{L})$, densidade celular $(\mathrm{Cel} / \mathrm{L})$ e biomassa $(\mathrm{mg} / \mathrm{L})$ do lago Paranoá no período de 1999-2011

\begin{tabular}{cccc}
\hline Estações* & Clorofila $\boldsymbol{a}$ & Densidade de células & Biomassa \\
\hline A & 8,000 & $3.576 .497,00$ & 0,430 \\
\hline B & 3,800 & $2.994 .406,00$ & 0,200 \\
\hline C & 3,985 & $2.305 .867,00$ & 0,150 \\
\hline D & 3,700 & $3.269 .094,00$ & 0,170 \\
\hline E & 6,250 & $2.294 .767,00$ & 0,200 \\
\hline
\end{tabular}

*Dados referentes a profundidade $1 \mathrm{~m}$ da superfície em todas as estações Fonte: Adaptado de Souza (2013)

Os valores apresentados na Tabela 5.1 mesmo não sendo exatamente o mesmo período de amostragem usado nos ensaios da PCR, refletem o quanto, historicamente, a biomassa do fitoplâncton é baixa no lago Paranoá, principalmente após a melhoria da qualidade da água. Esses dados podem ser úteis para justificar a quantidade reduzida de material genômico oriundo nesse trabalho.

Outrossim, vale salientar que as espécies identificadas, pelo monitoramento mensal da CAESB, são espécies do picoplâncton, o que implica em biomassa bem reduzida. Segundo Callieri (2005), as picocianobactérias são os principais componentes do fitoplâncton em águas oligotróficas. Elas são pequenas $(0,2$ a 2,0 $\mu \mathrm{m})$ e devido ao seu tamanho, podem passar por filtros com poros de 1 a $2 \mu \mathrm{m}$. Em ambientes oligo ou mesotróficos esses membros do picoplâncton são produtores primários importantes e algumas dessas pequenas espécies são bons competidores pelo fósforo, mas raramente produzem uma biomassa substancial (KOMÁREK, 2003).

Cianobactérias dos gêneros Aphanocapsa, Cyanodictyon e Epigloeosphaera pertencem à ordem Synechococcales, apresentam morfologia celular simples e podem formar colônias mucilaginosas. São espécies importantes do picoplâncton de corpos hídricos de água doce oligo e mesotrófico (KOMÁREK; KOMÁRKOVÁ; KLING, 2003; SANT’ANNA et al., 2004).

As pertencentes ao gênero Planktolyngbya estão incluídas na ordem Oscillatoriales e são cianobactérias filamentosas, de vida livre, solitárias e de livre flutuabilidade na água, com espécies sendo descritas em reservatórios de zonas temperadas e tropicais (KOMÁREK et al., 2003). Domingos et al. (1999) identificaram espécie de 
picocianobactéria do gênero Aphanocapsa como sendo a responsável pela produção de microcistina no primeiro relato de morte humana por cianotoxina que ocorreu no Brasil.

Wintzingerode, Göbel e Stackebrandt (1997) descrevem uma série de fatores que podem interferir nos resultados da PCR: (a) a quantidade e o tempo necessários para filtração das amostras podem influenciar na composição da microbiota; (b) a lise das células de amostras ambientais também pode interferir na qualidade do DNA genômico, consequentemente, do DNA alvo. Vários componentes bióticos e abióticos de ecossistemas ambientais, tais como partículas inorgânicas ou matéria orgânica, afetam a eficiência da lise e podem interferir com a purificação do DNA subsequente. Tais substâncias podem inibir a amplificação; (c) a diluição do DNA alvo; (d) a eficiência da hibridização do DNA alvo e os iniciadores; (e) a eficiência da extensão da DNA polimerase para todos os templates.

Assim, as amplificações geraram, em sua maioria, bandas fracas, consequentemente, contendo pouca concentração de DNA. Por isso, uma série de medidas foram adotadas a fim de otimizar as reações de PCR: novos iniciadores (primers) e dNTPS foram testados, nova Taq DNA polimerase foi utilizada, bem como a enzima Long Amp Taq DNA Polimerase. A otimização das reações de PCR foi uma tentativa de aumentar a quantidade de amplicons gerados para utilização nas reações de sequenciamento, e consequentemente, a identificação das cianobactérias presentes no lago. Amostras com boa quantidade de produtos de amplificação foram purificadas e sequenciadas.

Os produtos de PCR da porção $16 \mathrm{~S}$ do DNAr que foram sequenciados obtiveram 99\% - 100\% de similaridade com a sequência de Radiocystis sp. JJ30-12 (número de acesso: AM710388.1) com 98\% - 100\% de cobertura das sequências. Não foi possível a construção da árvore filogenética porque a maioria das sequências obtidas não apresentaram boa qualidade, o que indica a presença de possíveis contaminantes no DNA. Apenas as amostras coletadas em dezembro de 2012 (estação de coleta H), janeiro de 2014 (estações de coleta C, $\mathrm{D}$ e H) produziram sequências de boa qualidade no sequenciamento.

Ao contrário dos resultados obtidos nesse estudo, os dados do monitoramento do fitoplâncton realizado pela CAESB, por meio do uso da taxonomia clássica, demonstraram o predomínio de cianobactérias pertencentes ao gênero Aphanocapsa spp., enquanto que, os dados obtidos com o sequenciamento, identificaram a presença de cianobactérias do gênero Radiocystis sp. JJ30-12. 
As amostras também foram testadas para amplificação da região cpcBA-IGS, do operon da ficocianina. Dentre as amostras avaliadas apenas as amostras coletas em: janeiro de 2013 (pontos C e H), janeiro de 2014 (pontos C e E) e junho de 2013 (ponto B) amplificaram fragmento correspondente à ficocianina (Quadro 5.1). As bandas geradas apresentaram baixa intensidade, caracterizando pouca quantidade de produtos de amplificação (As imagens dos géis de agarose resultantes das amplificações da região cpcBA-IGS podem ser observadas no Apêndice 2).

Esse resultado é semelhante àqueles obtidos em amplificações usando os iniciadores da porção $16 \mathrm{~S}$ do DNAr, sugerindo, da mesma forma, que a qualidade do DNA alvo presente em amostras ambientais com baixa densidade do fitoplâncton, pode ter interferido na obtenção de concentrações maiores de amplicons ou até mesmo, podem ter sido responsáveis pela ausência de amplificações.

Algumas das amplificações geraram duas bandas. Além da qualidade do DNA alvo (Figura 5.1), a diversidade das sequências de cianobactérias brasileiras, possivelmente, explica os resultados das amplificações com os iniciadores utilizados nos ensaios de PCR.

Bittencourt-Oliveira, Piccin-Santos e Gouvêa-Barros (2012) utilizaram os oligonucleotídeos $c p c \mathrm{BA}$, da ficocianina, para amplificação de cianobactérias em amostras coletadas em reservatórios, utilizados para o abastecimento público, nos estados de São Paulo e Pernambuco. A amplificação de duas bandas também foi observada com estes oligonucleotídeos nas amostras avaliadas.

Pimentel (2009) realizou a avaliação qualitativa e quantitativa de cianobactérias em um reservatório e afirmou que os resultados dos testes da PCR de amostras ambientais dos iniciadores PC-IGS nem sempre geraram produtos de amplificação, apesar da presença de cianobactérias em todas as amostras. Os géis de agarose com os resultados das PCR desse gene também mostraram a presença de bandas duplas. A autora atribuiu a ausência de amplificações à presença de inibidores de amostras ambientais e/ou resíduos da extração de DNA.

Silva (2006) relatou a dificuldade em amplificar sequências usando os iniciadores $\mathrm{PC} \beta \mathrm{F} / \mathrm{PC} \alpha \mathrm{R}$ em algumas linhagens de cianobactérias. A autora afirma que essa dificuldade ocorre devido ao fato de que os iniciadores foram construídos usando as sequências disponíveis no GenBank em 1995 (NEILAN et al., 1995) com um número existente de 
sequências bastante limitado e sem cianobactérias brasileiras incluídas. A vantagem de se utilizar essa região do operon da ficocianina é que no domínio Bacteria esse pigmento é encontrado exclusivamente em cianobactérias, o que facilita a identificação desse grupo de micro-organismos em amostras ambientais.

\subsubsection{Investigação do potencial de biossíntese de microcistinas}

Para avaliar o potencial de biossíntese de microcistinas nas amostras de água foram realizados testes de PCR utilizando diferentes oligonucleotídeos, tendo como sequências alvo os genes relacionados com a síntese das microcistinas - mcyB e mcyD (iniciadores descritos no Quadro 4.3).

Os ensaios de PCR realizados com iniciadores relacionados com a biossíntese de microcistinas foram realizados com o intuito de detectar a presença de genes tóxicos nas amostras analisadas, o que caracterizaria a presença de cianobactérias potencialmente produtoras de microcistinas na área de estudo, por meio do uso de uma metodologia sensível, de fácil detecção e resultados rápidos - a técnica de PCR.

Os resultados obtidos para a amplificação de sequências de genes relacionados à síntese de microcistinas estão apresentados no Quadro 5.2. Apenas a amostra coletada em novembro de 2012, na estação E, amplificou a sequência de nucleotídeos do gene alvo mcyD. As reações de PCR das demais amostras, incluindo os ensaios de PCR com iniciadores do gene $m c y \mathrm{~B}$, amplificaram apenas a amostra utilizada como controle - NPLJ-4 (ver as imagens dos géis de agarose dos ensaios da PCR com os iniciadores dos genes $m c y \mathrm{~B}$ e $m c y \mathrm{D}$ no Apêndice 3).

Quadro 5.2 - Resultados das reações de PCR realizadas com os nucleotídeos iniciadores de biossíntese de microcistinas $m c y \mathrm{~B}$ e $m c y \mathrm{D}$

\begin{tabular}{|c|c|c|c|}
\hline Período de coleta & Amostras & $\boldsymbol{m c y B}$ & $\boldsymbol{m c y D}$ \\
\hline \multirow{4}{*}{ Agosto de 2012} & $\mathrm{~A}$ & - & - \\
\cline { 2 - 4 } & $\mathrm{B}$ & - & - \\
\cline { 2 - 4 } & $\mathrm{C}$ & - & - \\
\cline { 2 - 4 } & $\mathrm{D}$ & - & - \\
\cline { 2 - 4 } & $\mathrm{E}$ & - & - \\
\cline { 2 - 4 } & $\mathrm{G}$ & - & - \\
\cline { 2 - 4 } & $\mathrm{H}$ & - & - \\
\hline \multirow{3}{*}{ Novembro de 2012 } & $\mathrm{A}$ & - & + \\
\cline { 2 - 4 } & $\mathrm{C}$ & - & - \\
\hline
\end{tabular}




\begin{tabular}{|c|c|c|c|}
\hline Período de coleta & Amostras & mcyB & mcyD \\
\hline \multirow[t]{2}{*}{ Dezembro de 2012} & $\mathrm{~B}$ & - & - \\
\hline & $\mathrm{H}$ & - & - \\
\hline \multirow{6}{*}{ Janeiro de 2013} & $\mathrm{~A}$ & - & - \\
\hline & $\mathrm{B}$ & - & - \\
\hline & $\mathrm{C}$ & - & - \\
\hline & $\mathrm{D}$ & - & - \\
\hline & $E$ & - & - \\
\hline & $\mathrm{H}$ & - & - \\
\hline \multirow{6}{*}{ Junho de 2013} & $\mathrm{~A}$ & - & - \\
\hline & B & - & - \\
\hline & $\mathrm{C}$ & - & - \\
\hline & $\mathrm{D}$ & - & - \\
\hline & $\mathrm{E}$ & - & - \\
\hline & $\mathrm{G}$ & - & - \\
\hline \multirow{4}{*}{ Janeiro de 2014} & $\mathrm{C}$ & - & - \\
\hline & $\mathrm{D}$ & - & - \\
\hline & $\mathrm{E}$ & - & - \\
\hline & $\mathrm{H}$ & - & - \\
\hline \multirow{7}{*}{ Julho de 2014} & $\mathrm{~A}$ & - & - \\
\hline & $\mathrm{B}$ & - & - \\
\hline & $\mathrm{C}$ & - & - \\
\hline & $\mathrm{D}$ & - & - \\
\hline & $\mathrm{E}$ & - & - \\
\hline & $\mathrm{G}$ & - & - \\
\hline & $\mathrm{H}$ & - & - \\
\hline
\end{tabular}

(+) presença e (-) ausência de produtos de amplificação por PCR confirmado pela presença de banda em gel de agarose; *Amostra que amplificou fragmento com aproximadamente $297 \mathrm{pb}$, correspondente a região do gene mcyD.

Fonte: Elaborado pela autora

A ausência de amplificações possivelmente pode estar mais uma vez relacionada à qualidade do DNA genômico, conforme descrição no item 5.1.1, e à diversidade nas sequências nucleotídicas de cianobactérias tóxicas brasileiras, uma vez que, os iniciadores utilizados no estudo foram desenhados a partir de sequências nucleotídicas de cianobactérias encontradas em ambientes temperados.

O arranjo do grupo de genes produtores de microcistinas (mcyA-J) é diferente nas espécies de cianobactérias (NEILAN et al., 2008). Os iniciadores usados no estudo foram desenhados a partir de sequências do gene envolvido com a síntese de microcistina de linhagens de Microcystis (KAEBERNICK et al., 2000; NEILAN et al., 1999). Os dados do monitoramento realizado pela CAESB apontam a presença de cianobactérias dos gêneros Aphanocapsa, Cyanodictyon, Epigloeosphaera e Planktolyngbya no lago Paranoá. Dessa forma, as divergências nas sequências nucleotídicas das cianobactérias pertencentes a esses gêneros e as cianobactérias do gênero Microcystis, que foram usadas para o desenho dos 
iniciadores, provavelmente, podem explicar a ausência de amplificações das amostras testadas.

PIMENTEL (2009) afirma que há necessidade de utilização de nucleotídeos mais universais, que abranjam um maior número de gêneros ao mesmo tempo. $\mathrm{O}$ uso de iniciadores universais é extremamente importante para estudos em amostras ambientais, que podem conter vários gêneros produtores de microcistinas.

Bittencourt-Oliveira, Piccin-Santos e Gouvêa-Barros (2012) testaram 16 amostras de água com os mesmos iniciadores FAA/RAA $(m c y B)$ e apenas uma delas foi positiva. $\mathrm{O}$ resultado foi atribuído a variações nas sequências do gene $m c y \mathrm{~B}$ de populações de cianobactérias brasileiras, afetando o anelamento dos oligonucleotídeos e subestimando o potencial tóxico desses micro-organismos. Ao utilizar os oligonucleotídeos, relacionados com a biossíntese de microcistinas $(m c y \mathrm{~B})$, desenhados para populações de cianobactérias brasileiras, os autores obtiveram produtos de amplificação específicos em 99\% das amostras avaliadas.

Gomes (2014) também realizou a amplificação de cianobactérias potencialmente tóxicas com iniciadores moleculares, referentes à região do gene $m c y \mathrm{~B}$ e $m c y \mathrm{D}$, desenhados a partir de sequências gênicas de cepas potencialmente tóxicas brasileiras. Assim, o gene $m c y \mathrm{~B}$ foi identificado em $81,2 \%$ e o $m c y \mathrm{D}$ em $87,5 \%$ das amostras avaliadas.

Gomes (2008), utilizando os mesmos nucleotídeos de síntese do gene mcyD, usados nesse estudo, ressaltou que algumas das sequências amplificadas, em seu trabalho via PCR, não apresentaram o número de pares de bases esperado (sequências menores). Os resultados confirmam que o uso de iniciadores desenvolvidos para linhagens encontradas em ambientes temperados, para amplificar sequências de cepas brasileiras, pode explicar a razão pela qual os iniciadores utilizados não geraram produtos correspondentes às sequências alvo.

Algumas hipóteses são sugeridas para explicar esses resultados e dentre elas destaca-se a existência de mutantes naturais (MBEDI et al., 2005). Nos genes tóxicos podem ocorrer, além das mutações, eventos de recombinação, o que ocasionou a inativação dos genes, ao longo do processo evolutivo das cianobactérias (DITTMANN; BÖRNER, 2005).

Dessa forma, o desenho de iniciadores dos genes relacionados com a síntese de microcistinas, o que inclui as porções dos genes $m c y \mathrm{~B}$ e $m c y \mathrm{D}$, em populações de cianobactérias brasileiras, capazes de gerar produtos de amplificação a partir de diversos 
gêneros potencialmente tóxicos, deve ser considerado, a fim de evitar a obtenção de resultados falsos negativos.

\subsection{Discussão sobre a eficiência da PCR convencional no monitoramento de cianobactérias em ambientes aquáticos}

Atualmente, as metodologias usadas para o monitoramento de cianobactérias envolvem a avaliação do fitoplâncton para identificação e quantificação desses microorganismos, por meio do uso de microscopia. Essa metodologia requer tempo, pessoal treinado para identificação dos taxa, além de não ser capaz de separar linhagens tóxicas e nãotóxicas, uma vez que, a identificação baseia-se, de modo geral, em critérios morfológicos.

Dessa forma, é necessária a padronização de métodos capazes de identificar as cianobactérias, de forma mais rápida e precisa, avaliando a presença e/ou ausência de espécies potencialmente tóxicas, que possam ser utilizados em análises de rotina, nos programas de monitoramento ambiental, realizado por órgãos competentes em reservatórios de usos múltiplos.

A reação em cadeia da polimerase (PCR) encaixa-se nesse perfil, uma vez que é uma metodologia precisa. Os resultados obtidos nesse estudo mostraram que a técnica foi capaz de detectar cianobactérias, nas amostras coletadas em diferentes estações do lago Paranoá, pela presença de fragmentos de amplificação, visualizados em géis de agarose, utilizando os iniciadores específicos da porção do gene $16 \mathrm{~S}$ do DNAr nos ensaios.

A técnica pode ainda ser útil para detecção de picocianobactérias potencialmente tóxicas, já que esses micro-organismos são de difícil identificação pelos métodos tradicionais, devido ao seu pequeno tamanho, levando em consideração sua prevalência em reservatórios brasileiros, como é o caso do lago Paranoá, como potenciais produtores de cianotoxinas.

Os ensaios de PCR podem ser eficazes para a avalição precisa e para o direcionamento de estratégias de ação em recursos hídricos, uma vez que, o protocolo esteja padronizado, já que a análise consome tempo menor do que a identificação taxonômica tradicional, caso seja necessário, quando cianobactérias potencialmente tóxicas forem detectadas. Porém, a PCR convencional não permite avalição da concentração de toxinas, e então, outras metodologias devem ser acopladas ao monitoramento, a exemplo das reações de PCR em tempo real e/ou do teste de ELISA. 
Diversos trabalhos já foram realizados, usando variações da técnica de PCR, para quantificar genótipos tóxicos em populações de cianobactérias, presentes em reservatórios de água, utilizando ensaios de PCR em tempo real - PCR quantitativa (AL-TEBRINEH et al., 2011; GUEDES et al., 2014; KURMAYER; KUTZENBERGER, 2003).

É importante frisar que algumas linhagens não produtoras de toxinas podem conter os genes de biossíntese desses compostos. Devido a variações nos níveis de produção observados em diferentes linhagens, a análise molecular, por si só, não pode ser usada para avaliação quantitativa de toxinas em linhagens potencialmente tóxicas (DITTMANN; FEWER; NEILAN, 2013; PEARSON et al., 2016), podendo a quantificação de cianotoxinas ser feita por imunoensaios ou por cromatografia.

A detecção de cianobactérias tóxicas utilizando marcadores moleculares para microcistina apresenta uso potencial em análises de rotina de ecossistemas aquáticos. Assim, o monitoramento da água pode ser mais prático e permite aplicações rápidas de ações corretivas (BAKER et al., 2013; BITTENCOURT-OLIVEIRA, 2003). A PCR indicando a presença de cianobactérias tóxicas em corpos d'água pode orientar quanto à necessidade da quantificação acurada de toxinas (FOULDS et al., 2002).

Pimentel (2009) comparou a sensibilidade do método de PCR convencional e PCR quantitativa, sendo a última mais sensível do que a qualitativa (PCR convencional), detectando a presença do gene tóxico $m c y \mathrm{D}$ em todas as análises quantitativas, e o mesmo não ocorreu com a PCR convencional (Figura 5.2).
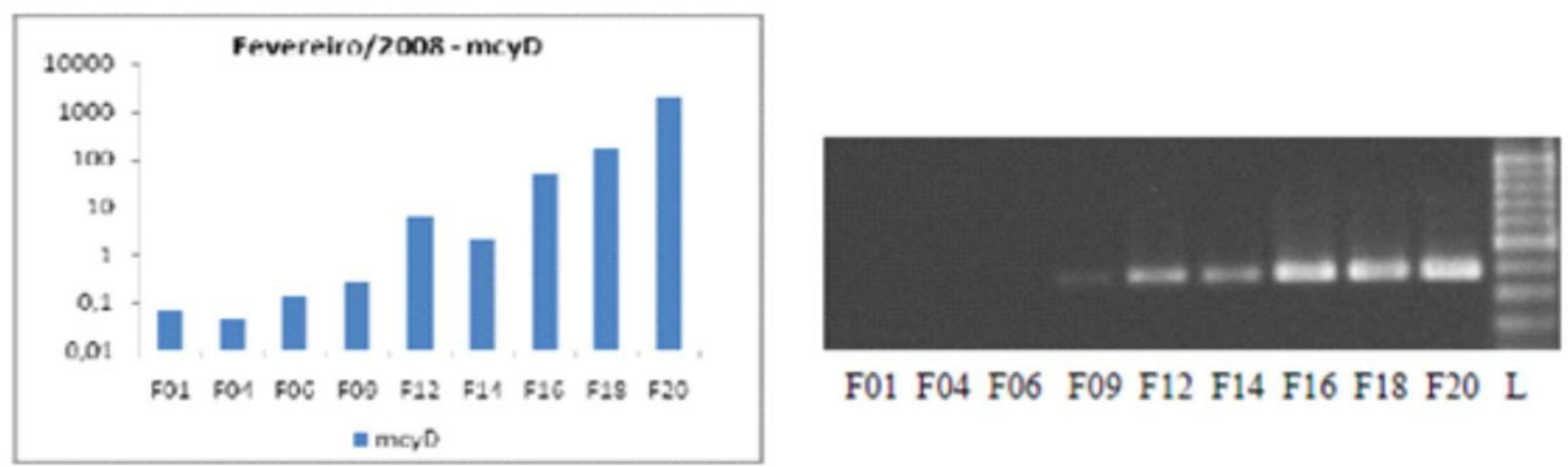

F01 F04 F06 F09 F12 F14 F16 F18 F20 L

Figura 5.2 - - Comparação da PCR quantitativa em cels.mL ${ }^{-1}$ e a PCR convencional de amostras ambientais. PCR quantitativa à esquerda e PCR convencional a direita

Fonte: Adaptado de Pimentel (2009) 
Por meio da aplicação de PCR para medir o potencial tóxico de uma floração, os gestores e gerentes responsáveis pelo acompanhamento das condições dos ambientes aquáticos destinados a usos múltiplos e, principalmente, ao abastecimento de água para consumo humano, tem acesso a um protocolo de avaliação de risco rápido. Isso permitiria implementações precoces de estratégias de controle para evitar a exposição humana às hepatotoxinas de cianobactérias antes que essas toxinas alcancem níveis perigosos (ALTEBRINEH et al., 2011; BARÓN-SOLA et al., 2012).

Pimentel e Giani (2013) afirmam que o uso de iniciadores específicos para detecção de cianobactérias potencialmente tóxicas por meio de reações de PCR ainda é raro no Brasil e que os métodos moleculares podem ter um papel importante nas práticas voltadas para o monitoramento ambiental. Essas abordagens oferecem novos procedimentos para a prevenção e controle efetivo de florações de cianobactérias tóxicas. Essa ferramenta pode dispor informações complementares à análise tradicional baseada apenas na morfologia das cianobactérias, com benefícios para a gestão e controle desses micro-organismos.

Assim, a detecção de cianobactérias tóxicas por métodos moleculares representa uma metodologia poderosa para análise de rotina em ecossistemas aquáticos, capaz de antecipar ações corretivas auxiliares no controle, embora estudos complementares de outras variáveis ambientais e biológicas sejam imprescindíveis (PIMENTEL, 2009). Oberholster et al. (2008) apud Pimentel (2009) criaram um modelo que consiste em um conjunto de técnicas de monitoramento e avaliação preventiva de cianobactérias (Figura 5.3). A estratégia sugere o uso de PCR para detecção rápida e precoce de cianobactérias tóxicas e medidas preventivas.

Dessa maneira, é possível avaliar a eficácia da utilização de métodos moleculares, baseados no uso das reações em cadeia da polimerase (PCR), em conjunto com outros protocolos analíticos, no monitoramento ambiental de reservatórios de usos múltiplos, como é o caso do lago Paranoá, pelos órgãos competentes, a fim de obter resultados rápidos e confiáveis no que diz respeito à presença das cianobactérias e o seu potencial tóxico em amostras ambientais. 


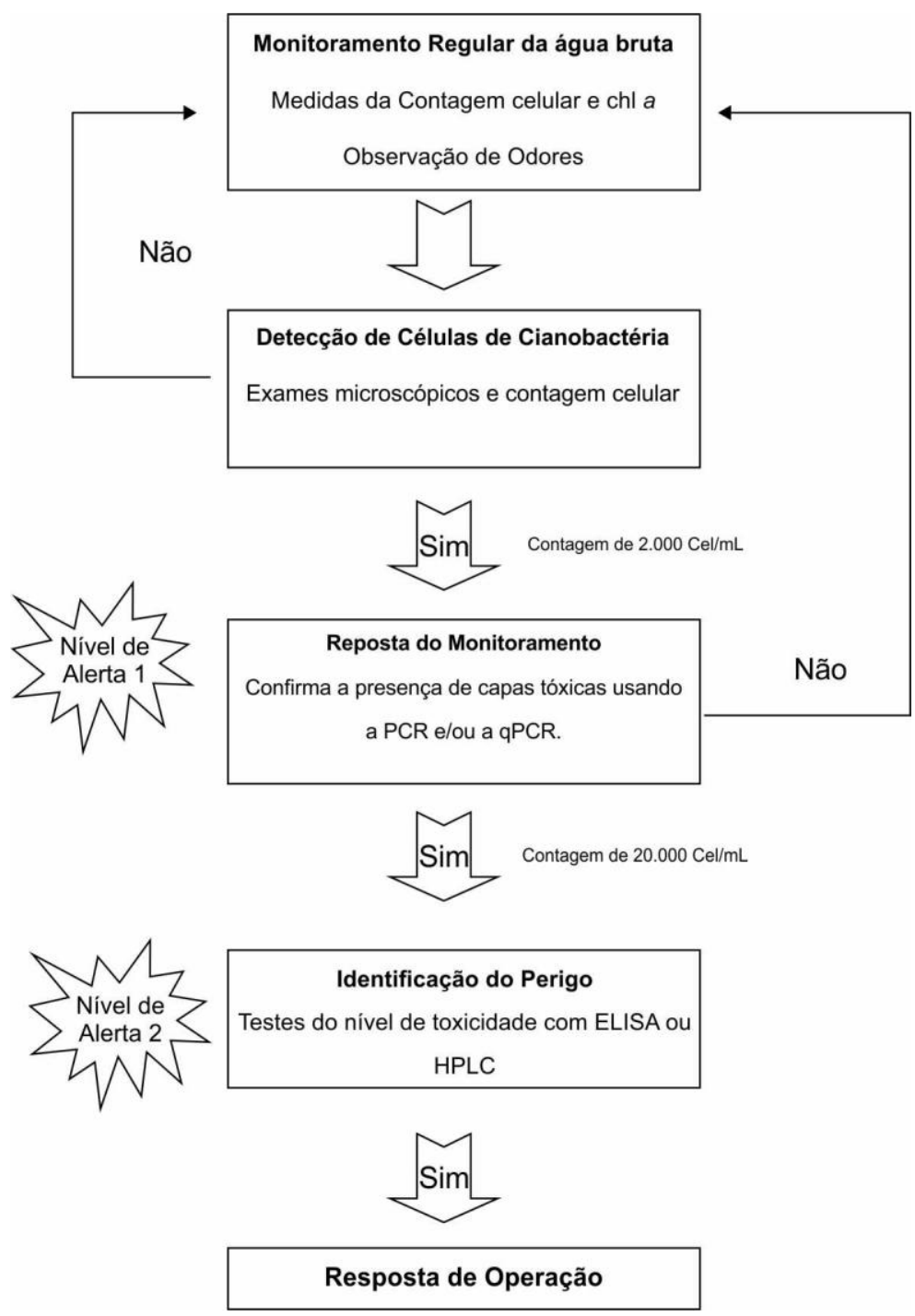

Figura 5.3 - Plano de monitoramento de cianobactéria usando a contagem celular e a PCR como indicadores primários da qualidade da água

Fonte: Adaptado de Oberholster et al. (2008) apud Pimentel (2009)

A partir dos resultados obtidos nesse estudo por meio da realização das reações de PCR não foi possível estabelecer um protocolo de avaliação de risco quanto à presença de cianobactérias potencialmente tóxicas no lago Paranoá, sendo necessários mais estudos relacionados com a área de estudo e o fluxograma descrito na Figura 5.3 poderia nortear os gestores responsáveis pela avalição e manutenção da qualidade da água de reservatórios de usos múltiplos, o que inclui o lago Paranoá: método tradicional de contagem microscópica com detecção de cianobactérias, confirmação da presença de linhagens potencialmente tóxicas por meio de reações de PCR tradicional e/ou quantitativa, testes de toxicidade usando ELISA 
e/ou HPLC caso o resultados das PCR sejam positivos e por fim, uma resposta do sistema de operação do reservatório.

\subsection{Investigação da toxicidade das amostras}

Os ensaios de PCR são úteis para detecção de cianobactérias e o potencial tóxico desses micro-organismos em amostras ambientais, porém, o método não permite a quantificação da toxina, caso haja a necessidade de se conhecer sua concentração. Por isso, o ensaio imunológico ELISA foi utilizado para a investigação da toxicidade das amostras (a descrição do método ELISA pode ser visualizada no item 3.5.3).

O teste foi realizado em duplicata e conseguiu quantificar as microcistinas em uma faixa de detecção que está entre 0,15 e $5 \mu \mathrm{g} / \mathrm{L}$. As amostras coletas em janeiro e junho de 2013 e em janeiro e julho de 2014 foram utilizadas para quantificação das hepatotoxinas microcistinas. Todas as amostras avaliadas foram positivas para a presença de microcistinas e quantificadas em $\mu \mathrm{g} / \mathrm{L}$ (Quadro 5.3). As amostras coletadas em julho de 2014 obtiveram os maiores valores de concentração das microcistinas.

Para a realização do teste de ELISA foi medida a toxina em sua forma particulada, contida no interior da célula, uma vez que, as amostras foram filtradas e o material retido no filtro, foi empregado para quantificação. Devido à falta de dados sobre o percentual de ocorrência das cianobactérias no período de julho de 2014 (Quadro 5.1), não há como relacionar a concentração de microcistinas detectada nessa época e a densidade de cianobactérias.

Quadro 5.3 - Resultado da quantificação de microcistinas em amostras de água coletadas no lago Paranoá

\begin{tabular}{|c|c|c|}
\hline Período de coleta & Ponto de coleta & Concentração de microcistina $(\boldsymbol{\mu g} / \mathbf{L})$ \\
\hline \multirow{3}{*}{ Janeiro de 2013} & $\mathrm{C}$ & $>5$ \\
\cline { 2 - 3 } & $\mathrm{D}$ & 2,33 \\
\cline { 2 - 3 } & $\mathrm{E}$ & 1,02 \\
\cline { 2 - 3 } & $\mathrm{H}$ & 1,08 \\
\hline \multirow{3}{*}{ Janeiro de 2014} & $\mathrm{C}$ & 2,35 \\
\cline { 2 - 3 } & $\mathrm{D}$ & 1,99 \\
\cline { 2 - 3 } & $\mathrm{E}$ & 1,58 \\
\cline { 2 - 3 } & $\mathrm{H}$ & 4,68 \\
\hline \multirow{3}{*}{ Junho de 2013} & $\mathrm{~A}$ & 0,39 \\
\cline { 2 - 3 } & $\mathrm{B}$ & 2,80 \\
\cline { 2 - 3 } & $\mathrm{C}$ & 0,20 \\
\cline { 2 - 3 } & $\mathrm{D}$ & 2,80 \\
\cline { 2 - 3 } & $\mathrm{E}$ & 0,20 \\
\cline { 2 - 3 } & $\mathrm{G}$ & 1,38 \\
\cline { 2 - 3 } & \multicolumn{2}{|c|}{} \\
\cline { 2 - 3 } & &
\end{tabular}




\begin{tabular}{|c|c|c|}
\hline Período de coleta & Ponto de coleta & Concentração de microcistina $(\boldsymbol{\mu g} / \mathbf{L})$ \\
\hline \multirow{3}{*}{ Julho de 2014 } & $\mathrm{A}$ & $>5$ \\
\cline { 2 - 3 } & $\mathrm{B}$ & 4,04 \\
\cline { 2 - 3 } & $\mathrm{C}$ & 3,99 \\
\cline { 2 - 3 } & $\mathrm{D}$ & $>5$ \\
\cline { 2 - 3 } & $\mathrm{E}$ & $>5$ \\
\cline { 2 - 3 } & $\mathrm{G}$ & 4,41 \\
\hline
\end{tabular}

Fonte: Elaborado pela autora

A ocorrência de maior concentração de microcistinas em julho de 2014, possivelmente se deve à presença de linhagens tóxicas e não-tóxicas em uma população de cianobactérias nesse período, contendo o agente de ligação das microcistinas ao anticorpo (porção Adda), uma vez que, o imunoensaio é capaz de detectar valores abaixo do valor de microcistinas recomendado pela OMS na água potável $-1 \mu \mathrm{g} / \mathrm{L}$. Ou ainda, devido à presença de substâncias eluídas com a toxina que podem interferir com os resultados obtidos. Dessa forma, pode ocorrer, provavelmente, uma superestimativa do valor da concentração de microcistinas na amostra.

Essa superestimação da quantidade de microcistinas presente em amostras ambientais pode ter ocorrido de modo geral, nos pontos avaliados nesse estudo, levando possivelmente, a resultados falso-positivos e isso está relacionado a diversos fatores. McElhiney e Lawton (2005) afirmam que o teste de ELISA é muito específico, sendo possível a detecção de valores abaixo de $1 \mu \mathrm{g} / \mathrm{L}$. Assim, a presença de formas conjugadas de microcistinas com menor toxicidade ou mesmo de cianobactérias não-tóxicas mas que possuem o aminoácido ADDA (porção tóxica das microcistinas utilizada para detecção da toxina por ELISA), em pequenas quantidades na amostra, podem superestimar a toxidade real.

Metcalf et al. (2000) afirmam que alguns fatores podem interferir na acurácia da quantificação de toxinas por meio dos testes de ELISA, são eles: o metanol, o pH, a concentração de sais e o uso de tubos e ponteiras de plástico na manipulação da amostra. Dentre tais fatores destaca-se o metanol - solvente usado para extração das microcistinas das células de cianobactérias. Esse composto quando usado em altas concentrações, permite a coeluição de outros compostos presentes na amostra com a toxina em questão (efeito matriz), resultando em ligações inespecíficas do conjugado proteína-microcistinas no teste. Esse viés pode interferir no valor real de microcistinas presente na amostra, produzindo então, resultados falso-positivos. 
Semelhante aos resultados encontrados nesse estudo, Fonseca et al. (2015) detectaram a presença de microcistinas em todas as amostras avaliadas usando o kit de ELISA, coletadas em reservatórios do Rio Grande do Norte, com concentrações acima do valor permitido para o consumo humano, em $27 \%$ das amostras avaliadas, conforme portaria MS $n^{\circ} 2.914$ de 12/12/2011, que regula os padrões de potabilidade da água. As análises microscópicas revelaram a presença de 21 espécies de cianobactérias, e 11 delas foram consideradas potencialmente produtoras de cianotoxinas, com predomínio das espécies produtoras de microcistinas: Microcystis aeruginosa, Anabaena circinalis e Planktothrix agardhii.

Bittencourt-Oliveira et al. (2014) detectaram a presença de microcistinas, por meio da realização do ensaio de ELISA, em todas as amostras de água analisadas, oriundas de reservatórios utilizados como fonte de abastecimento público, no Nordeste do Brasil (estado de Pernambuco), com exceção de um reservatório (Ipojuca), cuja presença de microcistinas não foi detectada. Os autores também identificaram as cianobactérias potencialmente tóxicas por meio de microscopia.

Esses resultados demonstram a importância do monitoramento da qualidade da água em reservatórios, assim como no lago Paranoá, uma vez que, esse manancial de usos múltiplos será utilizado para abastecimento público. 


\section{CONCLUSÕES}

Foi detectada a presença de cianobactérias (avaliação qualitativa), por meio do uso das reações de PCR convencional, em 97\% das amostras de água coletadas no lago Paranoá, no período de 2012 a 2014 e amplificadas com os iniciadores específicos da porção do $16 \mathrm{~S}$ DNAr (27F/809R).

Os iniciadores referentes à porção da ficocianina $(\mathrm{PC} \beta \mathrm{F} / \mathrm{PC} \alpha \mathrm{R})$ amplificaram somente 13,8\% das amostras avaliadas. Com relação aos oligonucleotídeos dos genes de síntese da microcistina ( $m c y \mathrm{~B}$ e $m c y \mathrm{D})$, apenas um deles - mcy $\mathrm{D}$ - amplificou fragmento em uma única amostra. Isso provavelmente ocorreu devido à baixa concentração do DNA alvo no DNA genômico extraído do fitoplâncton e à presença de interferentes da PCR em amostras ambientais.

O uso de iniciadores desenvolvidos para a amplificação de linhagens de cianobactérias presentes em ambiente temperado, possivelmente inibiu o anelamento desses oligonucleotídeos com as sequências variáveis de cianobactérias brasileiras. Dessa forma, há uma necessidade de desenvolvimento, padronização e utilização de nucleotídeos iniciadores específicos para linhagens de cianobactérias brasileiras.

Em função dos fatores que afetam as reações de PCR não foi possível estabelecer a padronização para estas análises no lago Paranoá, mesmo sendo um método preciso e de fácil manuseio, para o estabelecimento de padronização das reações de PCR que confirmem a presença de cianobactérias potencialmente tóxicas são necessários mais estudos e testes capazes de ajustar os fatores ambientais e os elementos utilizados nas reações de PCR, por exemplo, os iniciadores e concentrações dos reagentes e DNA molde, para a obtenção de resultados capazes de corroborar com os resultados oriundos da taxonomia clássica de identificação e contagem de cianobactérias usado atualmente em laboratórios responsáveis pela análise da presença desses micro-organismos em ecossistemas aquáticos de usos múltiplos.

Os resultados do sequenciamento indicaram baixa qualidade para a maioria das sequências obtidas, o que inviabilizou a construção da árvore filogenética. As sequências de boa qualidade apresentaram 100\% de similaridade com a sequência de Radiocystis sp. JJ30-12 (número de acesso: AM710388.1) com 98\% a 100\% de cobertura das sequências. Porém, as análises do fitoplâncton realizada pelo programa de monitoramento da CAESB revelaram o 
predomínio de cianobactérias dos gêneros Aphanocapsa, Cyanodictyon e Epigloeosphaera, Planktolyngbya. Essa diferença no resultado da identificação das cianobactérias nesse estudo e comparado com os dados de monitoramento da CAESB sugerem que a escolha do método analítico vai influenciar diretamente no resultado obtido.

A presença de microcistinas foi constatada em todas as amostras avaliadas. Vale ressaltar que, para o monitoramento da qualidade da água, em corpos hídricos de usos múltiplos, como é o caso do lago Paranoá, o teste de ELISA pode indicar mais rapidamente a presença de cianotoxinas em reservatórios, porém, sua associação com outra metodologia analítica para a confirmação dos seus resultados, como por exemplo, com o uso de HPLC a fim de minimizar o viés do método.

Levando-se em consideração a necessidade da utilização de metodologias analíticas capazes de indicar, de forma mais simples e rápida, a presença de cianobactérias possivelmente envolvidas com a síntese de cianotoxinas, o que pode nortear a tomada de decisão, em tempo hábil, com relação às medidas necessárias à manutenção da qualidade da água em reservatórios, pode-se afirmar que as reações de PCR, utilizando iniciadores específicos relacionados com a síntese de cianotoxinas, como por exemplo, as microcistinas, podem ser úteis para a otimização das metodologias analíticas usadas para o monitoramento de reservatórios, desde que levado em consideração todos os fatores que podem interferir na acurácia dos resultados. Dessa forma, eles poderiam ser incluídos nas análises de rotina, em programas de monitoramento da qualidade da água, sendo úteis para identificação de cianobactérias. 


\section{REFERÊNCIAS}

ADASA. Agência Reguladora de Águas, Energia e Saneamento Básico do Distrito Federal. Revisão e atualização do Plano de Gerenciamento Integrado de Recursos Hídricos do Distrito Federal: Relatório Final. v. 1. Diagnóstico. 2012. 795 p.

ADASA. Agência Reguladora de Águas, Energia e Saneamento Básico do Distrito Federal. Revisão e Atualização do Plano de Gerenciamento Integrado de Recursos Hídricos do Distrito Federal: Relatório Técnico Parcial 3. 2011a. 446 p.

ADASA. Agência Reguladora de Águas, Energia e Saneamento Básico do Distrito Federal. Condições de operação e usos múltiplos dos recursos hídricos do Lago Paranoá. SANTOS, V. Superintendência de Recursos Hídricos - SRH. 2011b. Disponível em: <http://www.recursoshidricos.df.gov.br/cbh_paranoa/apresentacoes.asp>. Acesso em: 02 set. 2016.

AFFE, H. M. de J. et al. Floración de Trichodesmium erythraeum en la región costera tropical de Brasil. Revista de Biología Marina y Oceanografía, v. 51, n. 1, p. 175-179, 2016.

AKÇAALAN, R. et al. Planktothrix rubescens: a perennial presence and toxicity in Lake Sapanca. Turkish Journal of Botany, v. 38, p. 782-789, 2014.

AL-TEBRINEH, J. et al. A new quantitative PCR assay for the detection of hepatotoxigenic cyanobacteria. Toxicon, n. 57, p. 546-554, 2011.

AL-TEBRINEH, J. et al. Community Composition, Toxigenicity, and Environmental Conditions During a Cyanobacterial Bloom Occurring Along 1,100 Kilometers of the Murray River. Appl Environ Microbiol., v. 78, n. 1, p. 263-272, 2012.

AL-TEBRINEH, J. et al. Detection of saxitoxin-producing cyanobacteria and Anabaena circinalis in environmental water blooms by quantitative PCR. Appl Environ Microbiol. v. 76, p. 7836-7842, 2010.

AMANN, R. I.; LUDWIG, W.; SCHLEIFER, K. H. Phylogenetic identification and in situ detection of individual microbial cells without cultivation. Microbiol Rev., n. 59, p. 143-169, 1995.

AMÉ, M. V.; DEL PILAR DÍAZ, M.; WUNDERLIN, D. A. Occurrence of toxic cyanobacterial blooms in San Roque Reservoir (Córdoba, Argentina): a field and chemometric study. Environmental Toxicology, v. 18, n. 3, p. 192-201, 2003.

ANGELINI, R.; BINI, L. M.; ATARLING, F. L. R. M. Efeitos de diferentes intervenções no processo de eutrofização no lago Paranoá (Brasília-DF). Oecol. Bras., v. 12, n. 3, p. 564-571, 2008 .

ANJOS, F. M. et al. Detection of harmful cyanobacteria and their toxins by both PCR amplification and LC-MS during a bloom event. Toxicon, v. 48, n. 3, p. 239-245, 2006.

AZEVEDO, M. F. O. et al. First report of microcystins from a Brazilian isolate of the cyanobacterium Microcystis aeruginosa. Journal of Applied Phycology, v. 6, n. 3, p. 261265, 1994. 
AZEVEDO, S. M. et al. Human intoxication by microcystins during renal dialysis treatment in Caruaru - Brazil. Toxicology, 181 - 182, p. 441-446, 2002.

BÁCSI, I.; B-BÉRES, V.; VASAS, G. Possible Roles of Cyanotoxins in Species Interactions of Phytoplankton Assemblages. In: FERRÃO-FILHO, A. da S. (ed.). Cyanobacteria: Ecology, Toxicology and Management. New York: Nova Science Publishers, 2013. p. 1-25.

BAKER, L. et al. Rapid, multiplex-tandem PCR assay for automated detection and differentiation of toxigenic cyanobacterial blooms. Molecular and Cellular Probes, v. 27, p. 208-214, 2013.

BARROS, M. A. M. Uma proposta didático-prática em um método de ensino de atividade especial por estudo do meio sob a disposição de navegação no lago Paranoá. 2010. 40 f. Monografia (Graduação em Educação Ambiental) - Universidade Candido Mendes, Brasília, 2010.

BARTRAM, J. et al. Introduction. In: CHORUS, I.; BARTRAM, J. (eds). Toxic cyanobacteria in water: A guide to their public health consequences, monitoring and management. London: WHO \& E\&FN Spon; p. 1-14, 1999.

BECKER, R. et al. Mapping Variations of Algal Blooms in the Lower Great Lakes. In: CONNERTON, M.; CRYSLER, C. (Eds.). Monitoring Harmful Algal Blooms. Great Lakes Research Review, v. 7, p. 14-17, 2006.

BECKER, V. et al. Occurrence of anatoxin-a(s) during a bloom of Anabaena crassa in a water-supply reservoir in southern Brazil. J Appl Phycol, v. 22, p. 235-241, 2010.

BELÓ, A. Comparação de floração de cianobactérias e níveis de parâmetros físicos, químicos e biológicos na represa de Alagados, Ponta Grossa - PR. 2015. $168 \mathrm{f}$. Dissertação (Mestrado Profissional em Meio Ambiente Urbano e Industrial - Setor de Tecnologia) - SENAI; Universidade de Stuttgart; Universidade Federal do Paraná, Curitiba, 2015 .

BITTENCOURT-OLIVEIRA, M. do C. Detection of potential microcystin-producing cyanobacteria in Brazilian reservoirs with a $m c y B$ molecular marker. Harmful Algae, n. 2, p. 51-60, 2003.

BITTENCOURT-OLIVEIRA, M. do C. et al. Cyanobacteria, microcystins and cylindrospermopsin in public drinking supply reservoirs of Brazil. An. Acad. Bras. Ciênc., v. 86, n. 1, p. 297-309, 2014.

BITTENCOURT-OLIVEIRA, M. do C. et al. Cylindrospermopsin in Water Supply Reservoirs in Brazil Determined by Immunochemical and Molecular Methods. Journal of Water Resource and Protection, n. 3, p. 349-355, 2011.

BITTENCOURT-OLIVEIRA, M. do C.; MOLICA, R. Cianobactérias Invasoras: aspectos moleculares e toxicológicos de Cylindrospermopsis raciborskii no Brasil. Revista Biotecnologia Ciência e Desenvolvimento, n. 30, 2003.

BITTENCOURT-OLIVEIRA, M. do C.; PICCIN-SANTOS, V.; GOUVÊA-BARROS, T. Microcystin-Producing Genotypes from Cyanobacteria in Brazilian Reservoirs.

Environmental Toxicology, n. 27, v. 8, p. 461-471, 2012. 
BITTENCOURT-OLIVEIRA, M.; SANTOS, D.; MOURA, N. Toxic cyanobacteria in reservoirs in northeastern Brazil: detection using a molecular method. Brazilian Journal of Biology, 70(4), p. 1005-1010, 2010.

BLÁHA, L.; BABICA, P.; MARSÁLEK, B. Toxins produced in cyanobacterial water blooms - toxicity and risks. Interdiscip Toxicol., n. 2, v. 2, p. 36-41, 2009.

BONILLA, S. et al. What drives the distribution of the bloom-forming cyanobacteria Planktothrix agardhii and Cylindrospermopsis raciborskii? FEMS Microbiol Ecol, v. 79, p. 594-607, 2012.

BRANCO, C. W. C.; SENNA, P. A. C. The taxonomic elucidation of the Paranoá Lake (Brasilia, Brazil) problem: Cylindrospermopsis raciborskii. Bulletin du Jardin Botanique National de Belgique, v.61, p.85-91. 1991.

BRANCO, C. W. C.; SENNA, P. A. C. Factors influencing the development of Cylindrospermopsis raciborskii and Microcystis aeruginosa in the Paranoá Reservoir, Brasília, Brazil. Algological Studies, v. 75, p. 85-96, 1994.

BRANDÃO, C. J. et al.(Org.). Guia nacional de coleta e preservação de amostras: água, sedimento, comunidades aquáticas e efluentes líquidos. São Paulo: CETESB; Brasília: ANA, 2011. 326 p.

BRASIL. Resolução CONAMA n ${ }^{\circ}$ 357, de 17 de março de 2005. Dispõe sobre a classificação dos corpos de água e diretrizes ambientais para o seu enquadramento, bem como estabelece as condições e padrões de lançamento de efluentes, e dá outras providências. D.O.U. $n^{\circ} 053$, de 18 mar. 2005, p. 58-63.

BRASIL. Ministério da Saúde. Portaria no 2914, de 12 de dezembro de 2011. Dispõe sobre os procedimentos de controle e de vigilância da qualidade da água para consumo humano e seu padrão de potabilidade, 2011.

BURFORD, M. A. et al. Nutrient-related changes in the toxicity of field blooms of the cyanobacterium, Cylindrospermopsis raciborski. FEMS Microbiol Ecol. n. 89, v. 1, p. 135$148,2014$.

BURNETT, J. A. B.; MATTOS, S. P.; AZZOLIN, N. M. P. Intervenções da Companhia de Saneamento. In: FONSECA, F. O (Org.). Olhares sobre o Lago Paranoá. Brasília: Secretaria do Meio Ambiente e Recursos Hídricos, 2001. p. 199-211.

CAESB, Companhia de Saneamento Ambiental do Distrito Federal. Projeto Básico para Ampliação dos Sistemas de Abastecimento de Água do Distrito Federal Utilizando como Manancial o Lago Paranoá. v. 1. Brasília: Consórcio Themagna, 2005. 23 p.

CAESB, Companhia de Saneamento Ambiental do Distrito Federal. Lago Paranoá: 5 décadas de muitas transformações. LUDUVICE, M. $1^{\circ}$ Workshop sobre o Assoreamento do Lago Paranoá. Brasília, 2011a.

CAESB, Companhia de Saneamento Ambiental do Distrito Federal. Sistema de Abastecimento de Água: Panorama Atual e Futuro, 2011b. Disponível em: <http://www.recursoshidricos.df.gov.br/cbh_paranoa/apresentacoes/Caesb_CRHDF.pdf >. Acesso em: 02 set. 2016. 
CALLIERI, C. Picophytoplankton in freshwater ecosystems: the importance of small-sized phototrops. Freshwater Reviews, v. 1, p. 1-28, 2007.

CARMICHAEL, W. W. Cyanobacteria secondary metabolites - The Cyanotoxins. J. Appl. Bact., v. 72, p. 445-459, 1992.

CARMICHAEL, W. W. The Toxins of Cyanobacteria: These poisons, which periodically and fatally contaminate the water supplies of wild and domestic animals, can also harm humans. But they are being coaxed into doing good. Scientific American, 1994.

CARMICHAEL, W. W. et al. Evidence for Paralytic Shellfish Poisons in the Freshwater Cyanobacterium Lyngbya wollei (Farlow ex Gomont) comb. nov. Applied and Environmental Microbiology, v. 63, n. 8, p. 3104-3110, 1997.

CARMICHAEL, W. W. et al. Human fatalities from cyanobacteria: Chemical and biological evidence for cyanotoxins. Environmental Health Perspectives, v. 109, n. 7, p. 663-668, 2001.

CARMICHAEL, W. W.; MAHMOOD, N. A.; HYDE, E. G. Natural Toxins from Cyanobacteria (Blue-Green Algae). In: HALL, S.; STRIEHARTZ, G. (Eds.). Marin Toxins: Origin, Structure and Molecular Pharmacology. American Chemical Society, Washington, D. C. p. 87-106, 1990.

CARVALHO, L. R. et al. Cyanobacterial Bloom In An Urban Coastal Lake, Rio Grande Do Sul State, Southern Brazil. Brazilian Journal of Microbiology, v. 39, p. 761-769, 2008.

CARVALHO, M. do C. el al. Manual de cianobactérias planctônicas: legislação, orientações para o monitoramento e aspectos ambientais. São Paulo: CETESB, 2013. 47 p.

CATHERINE, Q. et. al. A review of current knowledge on toxic benthic freshwater cyanobacteria e Ecology, toxin production and risk management. Water Research, p. 1-16, 2013.

CEBALlOS, B. S. O. de.; AZEVEDO, S. M. F. de O.; BENDATE, M. M. de A. Fundamentos Biológicos e Ecológicos Relacionados às Cianobactérias. In: PÁDUA, V. L. (Coord.). Contribuição ao estudo da remoção de cianobactérias e microcontaminantes orgânicos por meio de técnicas de tratamento de água para consumo humano, Rio de Janeiro: ABES, 2006. p. 21-81.

CETESB. Determinação de clorofila $a$ e feofitina $a$ : método espectrofotométrico. Companhia Ambiental do Estado de São Paulo. L5.306, 14 p., 2014.

CHELLAPPA, N. T.; CHELLAPPA, S. L.; CHELLAPPA, S. Harmful Phytoplankton Blooms and Fish Mortality in a eutrophicated reservoir of Northeast Brazil. Brazilian Archives of Biology and Technology, v. 51, n. 4, p.833-841, 2008.

CHEN, H.; BURKE, J. M.; PREPAS, E. E. Cyanobacterial Toxins in Fresh Waters. Encyclopedia of Environmental Health, p. 860-871, 2011.

CHEN, Y.; SHEN, D.; FANG, D. Nodularins in poisoning. Clinica Chimica Acta, v. 425, p. 18-29, 2013. 
CHISLOCK, M. F. et al. Eutrophication: Causes, Consequences, and Controls in Aquatic Ecosystems. Nature Education Knowledge, v. 4, n. 4, p. 1-8, 2013.

CHORUS, I.; BARTRAM, J. Toxic cyanobacteria in water: a guide to public health consequences, monitoring and management. World Health Organization. London and New York, 416 p, 1999.

CHRISTAKI, E.; BONOS, E.; FLOROU-PANERI, P. Innovative Microalgae Pigments as Functional Ingredients in Nutrition. In: KIM, S. (Ed.). Handbook of Marine Microalgae: Biotechnology Advances, p. 233-243, 2015.

CODD, G. A. Cyanobacterial toxins: occurrence, properties and biological significance. Wal. Sci. Tech., v. 32, n. 4, p. 149-156, 1995.

CODD, G. A. et al. Harmful Cyanobacteria From Mass Mortalities to Management Measures. In: HUISMAN, J.; MATTHIJS, H.C.P.; VISSER. P.M. (eds). Harmful Cyanobacteria. Springer; Dordrecht, The Netherlands: p. 1-23, 2005.

CODD, G. A. et al. Publication in 1672 of animal deaths at the Tuchomskie Lake, northern Poland and a likely role of cyanobacterial blooms. Toxicon, v. 108, p. 285-286, 2015.

CORDEIRO-ARAÚJO, M. K. et al. Dinâmica fitoplanctônica relacionada às condições ambientais em reservatório de abastecimento público do semiárido brasileiro. Rev. Bras. Ciênc. Agrár. Recife, v. 5, n. 4, p. 592-599, 2010.

CORRÊA, A. C. G. Modelos qualitativos de simulação sobre a dinâmica do plâncton em diferentes estados de trofia no lago Paranoá, DF. 2011. 140 f. Dissertação (Mestrado em Ecologia) - Programa de Pós-Graduação em Ecologia. Instituto de Ciências Biológicas, Universidade de Brasília, Brasília, DF, 2011.

COSTA, C. L. Avaliação e monitoramento de cianobactérias potencialmente tóxicas no açude Acarape do Meio, Redenção (Ceará, Brasil). 2010. 69 f. Monografia (Bacharelado em Ciências Biológicas) - Centro de Ciências da Saúde, Universidade Estadual do Ceará, Fortaleza, CE, 2010.

COSTA, I. A. S. et al. Occurrence of toxin-producing cyanobacteria blooms in a brazilian semiarid reservoir. Brazilian Journal Biology. v. 66, n. 1B, p. 211-219, 2006.

COSTA, S. D. da et al. Algas e Cianobactérias Continentais no Estado do Pará, Brasil. Belém/PA: Embrapa Amazônia Oriental, p. 27-48, 2014.

CRUZ, F. S.; OLIVEIRA, A. C. P. de; GÔMARA, G. A. Monitoramento Da Comunidade De Cianobactérias No Complexo Lagunar De Jacarepaguá No Período De 2011 a 2012. Revista Eletrônica Novo Enfoque, v. 15, p. 90-95, 2012.

DAVIS, T. W. et al. The effects of temperature and nutrients on the growth and dynamics of toxic and non-toxic strains of Microcystis during cyanobacteria blooms. Harmful Algae, v. 8, p. 715-725, 2009.

DEVLIN, J. P. et al. Anatoxin-a, a toxic alkaloid from Anabaena flos-aquae NRC-44h. CAN. J. CHEM. v. 55, p. 1367-1371, 1977. 
DÍEZ, B.; ININBERGS, K. Ecological importance of cyanobacteria. In: SHARMA, N. K.; RAI, A. K. \& STAL, L. J. (Ed.). Cyanobacteria An Economic Perspective. Chichester: Wiley Blackwell, p. 43-63, 2014.

DILLENBERG, H. O.; DEHNEL, M. K. Toxic water bloom in Saskatchewan. Canadian Medical Association Journal, n. 83, p. 1151-1154, 1959.

DISTRITO FEDERAL. Secretaria de Infraestrutura e Obras do Distrito Federal SEINFRA/DF. Plano de Gerenciamento Integrado dos Recursos Hídricos do Distrito Federal - PGIRH/DF. Brasília - DF, 101 p., 2005.

DITTMANN, E.; BÖRNER, T. Genetic contributions to the risk assessment of microcystin in the environment. Toxicology and Applied Pharmacology, v. 203, p. 192- 200, 2005.

DITTMANN, E.; FEWER, D. P.; NEILAN, B. A. Cyanobacterial toxins: biosynthetic routes and evolutionary roots. FEMS Microbiol Rev, v. 37, p. 23-43, 2013.

DOMINGOS, P. et al. First Report of Microcystin Production by Picoplanktonic Cyanobacteria Isolated from a Northeast Brazilian Drinking Water Supply. Environmental Toxicology, v. 14, p. 31-35, 1999.

DOMINGUES, A. L. et al. Características espectrais de uma floração de cianobactérias no reservatório Rodolfo Costa e Silva - RS. In: Simpósio Brasileiro de Sensoriamento Remoto, 2011, Rio Grande do Sul. Anais do XV Simpósio Brasileiro de Sensoriamento Remoto. Rio Grande do Sul, p. 8452, 2011.

DORR, F. A. et al. Microcystins in South American aquatic ecosystems: Occurrence, toxicity and toxicological assays. Toxicon, n. 56, p. 1247-1256, 2010.

DRUGĂ, B. et al. Molecular characterization of microcystin-producing cyanobacteria from Romanian fresh waters. Eur. J. Phycol., v. 48, n. 3, p. 287-294, 2013.

ECHEVERRIA, R. M. Avaliação de impactos ambientais nos tributários do lago Paranoá, Brasília - DF. 2007. 132 f. Dissertação (Mestrado em Geologia) - Instituto de Geociências, Universidade de Brasília, Brasília, 2007.

EDLER, L.; ELBRÄCHTER, M. The Utermöhl method for quantitative phytoplankton analysis. In: KARLSON, B.; CUSACK, C.; BRESNAN, E. (Eds.) Microscopic and molecular methods for quantitative phytoplankton analysis. UNESCO (IOC Manuals and Guides, $n^{\circ}$ 55.) (IOC/2010/MG/55). Paris: United Nations Educational, Scientific and Cultural Organization, 2010. p. 13-20.

EPA, United States Environmental Protection Agency. Cyanobacterial Harmful Algal Blooms: Causes and Prevention. 2016. Disponível em: <http://www.epa.gov/nutrient-policydata/causes-and-prevention> Data de acesso: 10 mar. 2016.

FALCONER, I. An overview of problems caused by toxic blue-green algae (cyanobacteria) in drinking water. Environmental Toxicology, v.14, p. 5-12, 1999.

FALCONER, I. R. Health effects associated with controlled exposures to cyanobacterial toxins. Adv Exp Med Biol., n. 619, p. 607-612, 2008. 
FALCONER, I. et al. Safe levels and safe practices. In: CHORUS, I.; BARTRAM, J. (Ed.). Toxic Cyanobacteria in Water: A guide to their public health consequences, monitoring and management. London: E \& FN Spon, 1999. p. 161-182.

FERNANDES, V. O. et al. Ecologia de Cianobactérias: Fatores Promotores e Consequências das Florações. Oecol. Bras., v. 13, n. 2, p. 247-258, 2009.

FERRÃO-FILHO, A. S. et al. Florações de Cianobactérias tóxicas no Reservatório do Funil: dinâmica sazonal e consequências para o zooplâncton. Oecol. Bras., v. 13, n. 2, p. 346-365, 2009.

FERRER, G. G.; DEL NEGRO, G. Unidades de Conservação Ambiental da Bacia do Lago Paranoá. REDUnB, v. 10, p. 365-399, 2012.

FEWER, D. P. el al. New Structural Variants of Aeruginosin Produced by the Toxic Bloom Forming Cyanobacterium Nodularia spumigena. Plos One, v. 8, n. 9, p. 1-10, 2013.

FIGUEREDO, C. C.; GIANI, A.; BIRD, D. F. Does Allelopathy Contribute to Cylindrospermopsis raciborskii (Cyanobacteria) Bloom Occurrence and Geographic Expansion? J. Phycol., v. 43, p. 256-265, 2007.

FLYNN, K. J. Attack is not the best form of defense: Lessons from harmful algal bloom dynamics. Harmful Algae, n. 8, p. 129-139, 2008.

FOULDS, I. V. et al. Quantification of microcystin-producing cyanobacteria and E. coli in water by 5ф-nuclease PCR. Journal of Applied Microbiology, v. 93, p. 825-834, 2002.

FONSECA, F. O. (Org.). Olhares sobre o Lago Paranoá. Brasília: Secretaria de Meio Ambiente e Recursos Hídricos, 2001. 425 p.

FONSECA, J. R. et al. Cyanobacterial occurrence and detection of microcystins and saxitoxins in reservoirs of the Brazilian semi-arid. Acta Limnologica Brasiliensia, v. 27, n. 1, p. 78-92, 2015.

FOSS, A. Paralytic Shellfish Toxins Characterized From Lyngbya wollei Dominated Mats Collected From Two Florida Springs. 2011. 97 f. Master of Science. University of Florida, 2011.

FRANCIS, G. Poisonous Australian lakes. Nature, n. 18, p. 11-12, 1878.

FREITAS, T. C. de et al. Análise Qualitativa e Toxicológica de uma Floração de Cianobactérias na Lagoa do Gambá em Ouro Preto, MG, e uma Síntese da Ocorrência de Florações de Cianobactérias no Brasil. RBRH - Revista Brasileira de Recursos Hídricos, n. 3, v. 17, p. 17-28, 2012.

FROSCIO, S. M. et al. Interaction of the cyanobacterial toxin cylindrospermopsin with the eukaryotic protein synthesis system. Toxicon, 51, p. 191-198, 2008.

FUNASA. Fundação Nacional de Saúde. Potencial de florações de cianobactérias em um reservatório de abastecimento doméstico no Estado do Espírito Santo (reservatório Duas Bocas - Cariacica - ES). Brasília/DF: Funasa, 2007. 82 p. 
GADEMAN, K.; PORTMAN, C. Secondary metabolites from cyanobacteria: complex structures and powerful bioactivities. Curr Org Chem, v. 12, p. 326-341, 2008.

GOMES, J. Avaliação Da Floração Da Cianobactéria Cylindrospermopsis raciborskii Na Represa De Alagados, Ponta Grossa, Paraná. 2011. 104 f. Dissertação (Mestrado Profissioal em Meio Ambiente Urbano). Universidade Federal do Paraná, Curitiba, 2011.

GOMES, L. N. L. Estudo da associação entre parâmetros bióticos e abióticos e a ocorrência de florações de cianobactérias no reservatório de Vargem das Flores - MG. 2008. 183 f. Tese (Programa de Pós-graduação em Saneamento, Meio Ambiente e Recursos Hídricos). Universidade Federal de Minas Gerais, Belo Horizonte, MG, 2008.

GOMES, L. N. L. et al. Association between biotic and abiotic parameters and the occurrence of cyanobacteria in a Brazilian reservoir. Environ Monit Assess, v. 184, p. 4635-4645, 2012.

GOMES, Y. M. Avaliação da Presença de Cianobactérias Potencialmente Tóxicas e Microcistinas nas Lagoas Hipereutróficas na Região da Grande Vitória, ES. 2014. 97 f. Dissertação (Programa de Pós-Graduação em Engenharia Ambiental). Universidade Federal do Espírito Santo, Vitória, ES, 2014.

GRANÉLI, E.; WEBERG, M.; SALOMON, P. S. Harmful algal blooms of allelopathic microalgal species: The role of eutrophication. Harmful Algae, n. 8, p. 94-102, 2008.

GUEDES, I. A. et al. Fluctuations in microcystin concentrations, potentially toxic Microcystis and genotype diversity in a cyanobacterial community from a tropical reservoir. Harmful Algae, n. 39, p. 303-309, 2014.

HA, J. H.; HIDAKA, T.; TSUNO, H. Quantification of Toxic Microcystis and Evaluation of Its Dominance Ratio in Blooms Using Real-Time PCR. Environ. Sci. Technol., v. 43, p. 812-818, 2009.

HARADA, K.; KONDO, F.; LAWTON, L. Laboratory Analysis of Cyanotoxins. In: CHORUS, I.; BARTRAM, J. (Eds.) Toxic cyanobacteria in water: a guide to public health consequences, monitoring and management. World Health Organization. London and New York, p. 362-400, 1999.

HILBORN, E. D. el al. Sublethal Microcystin Exposure and Biochemical Outcomes among Hemodialysis Patients. PLoS One, v. 8, n. 7, p. 1-9, 2013.

HO, J. C.; MICHALAK, A. M. Challenges in tracking harmful algal blooms: A synthesis of evidence from Lake Erie. Journal of Great Lakes Research, v. 41, p. 317-325, 2015.

HOFF-RISSETI, C. et al. Cylindrospermopsin and Saxitoxin Synthetase Genes in Cylindrospermopsis raciborskii Strains from Brazilian Freshwater. Plos One, v. 8, n. 8, p. 114, 2013.

HOLLAND, A.; KINNEAR, S. Interpreting the Possible Ecological Role(s) of Cyanotoxins: Compounds for Competitive Advantage and/or Physiological Aide? Mar. Drugs, v. 11, p. 2239-2258, 2013. 
HOTTO, A. M.; SATCHWELLA, M. F.; BERRY, D. L.; GOBLER, C. J.; BOYER, G. L. Spatial and temporal diversity of microcystins and microcystin-producing genotypes in Oneida Lake, NY. Harmful Algae, n. 7, p. 671-681, 2008.

ISLES, P. D. F. et al. Dynamic internal drivers of a historically severe cyanobacteria bloom in Lake Champlain revealed through comprehensive monitoring. Journal of Great Lakes Research, p. 1-12, 2015.

JARDIM, F. A. et al. Fatores determinantes das florações de cianobactérias na água do Rio Doce, Minas Gerais, Brasil. Eng Sanit Ambient, v.19, n. 3, p. 207-218, 2014.

JOCHIMSEN, E. M. et al. Liver failure and death after exposure to microcystins at a hemodialysis center in Brazil. The New England Jornal of Medicine, v. 338, n. 13, p. 873878, 1998.

JUNGBLUT, A. D. et al. Diversity within cyanobacterial mat communities in variable salinity meltwater ponds of McMurdo Ice Shelf, Antarctica. Environ. Microbiol. v. 7, p. 519$529,2005$.

KAEBERNICK, M. et al. Light and the Transcriptional Response of the Microcystin Biosynthesis Gene Cluster. Applied and Environmental Microbiology, v. 66, n. 8, p. 3387$3392,2000$.

KARLSON, B. et al. Introduction to methods for quantitative phytoplankton analysis. In: KARLSON, B.; CUSACK, C.; BRESNAN, E. (Eds.) Microscopic and molecular methods for quantitative phytoplankton analysis. UNESCO (IOC Manuals and Guides, $\mathrm{n}^{\circ} 55$.) (IOC/2010/MG/55). Paris: United Nations Educational, Scientific and Cultural Organization, p. 5-12, 2010.

KFIR, R.; JOHANNSEN, E.; BOTES, D. P. Monoclonal Antibody Specific for Cyanoginosin-LA: Preparation and Characterization. Toxicon, v. 24, n. 6, p. 543-552, 1986.

KOMÁREK, J. Coccoid and Colonial Cyanobacteria. In: WEHR, J. D. and SHEATH, R.G. (Eds.), Freshwater Algae of North America: Ecology and Classification. 2nd ed. USA: Academic Press, p. 59-116, 2003.

KOMÁREK, J. et al. Background of the Caruaru tragedy; a case taxonomic study of toxic cyanobacteria. Algological Studies, 103, p. 9-29, 2001.

KOMÁREK, J.; KOMÁRKOVÁ, J. Review of the European Microcystis-morphospecies (Cyanoprokaryotes) from nature. Czech Phycology, v. 2, p. 1-24, 2002.

KOMÁREK, J.; KOMÁRKOVÁ, J.; KLING, H. Filamentous Cyanobacteria. In: WEHR, J. D. and SHEATH, R.G. (Eds.), Freshwater Algae of North America: Ecology and Classification. 2nd ed. USA: Academic Press, p. 117-196, 2003.

KOSKENNIEMI, K. et al. Quantitative Real-Time PCR Detection of Toxic Nodularia Cyanobacteria in the Baltic Sea. Appl Environ Microbiol., v. 73, n. 7, p. 2173-2179, 2007.

KOTAKA, F.; LEITE, C. M. B.; GADOTTI, R. F. Programa de pesquisas da Funasa: ocorrência de cianobactérias em dois reservatórios brasileiros, nos estados do ES e RJ, Duas 
Bocas-ES e Funil-RJ. In: 35 ASSEMBLÉIA NACIONAL DA ASSEMAE, 2005, Belo Horizonte-MG. Anais... São Paulo-SP: Assemae, 2005.

KURMAYER, R.; KUTZENBERGER, T. Application of Real-Time PCR for Quantification of Microcystin Genotypes in a Population of the Toxic Cyanobacterium Microcystis sp. Applied and Environmental Microbiology, v. 69, n. 11, p. 6723-6730, 2003.

LAJEUNESSE, A. et al. Detection and confirmation of saxitoxin analogues in freshwater benthic Lyngbya wollei algae collected in the St. Lawrence River (Canada) by liquid chromatography - tandem mass spectrometry. Journal of Chromatography A, v. 1219, p. 93-103, 2012.

LANE, C. E. et al. Homogeneous detection of cyanobacterial DNA via polymerase chain reaction. Letters in Applied Microbiology, v. 55, p. 376-383, 2012.

LAWTON, L. et al. Determination of Cyanobacteria in the Laboratory. In: CHORUS, I. and BARTRAM, J. (eds). Toxic cyanobacteria in water: A guide to their public health consequences, monitoring and management. London: WHO \& E\&FN Spon; p. 334-361, 1999.

LI, A. et al. Detection of the neurotoxin BMAA within cyanobacteria isolated from freshwater in China. Toxicon, v. 55, p. 947-953, 2010.

LI, D.; GU, A. Z.; HE, M. Quantification and genetic diversity of total and microcystinproducing Microcystis during blooming season in Tai and Yang-cheng lakes, China. Journal of Applied Microbiology, p. 1-13, doi:10.1111/jam.12456, 2014.

LIMA, L. M. Conceitos Básicos de Técnicas em Biologia Molecular. Campina Grande, PB: EMBRAPA ALGODÃO, 2008. 27 p.

LIMA, V. F. et al. Caracterização dos Níveis Populacionais de Cianobactérias no Açude Jacurici em Itiúba - Bahia. Enciclopédia Biosfera, Centro Científico Conhecer, v.9, n.16; p. 35-46, 2013.

LINS, R. P. M. et al. Cyanobacteria in a eutrophicated reservoir in a semi-arid region in Brazil: dominance and microcystin events of blooms. Brazilian Journal of Botany, v. 39, n. 2, p. 583-591, 2016.

LORENZI, A. S. Abordagens moleculares para detectar cianobactérias e seus genótipos produtores de microcistinas presentes nas represas Billings e Guarapiranga. 2004. 92 f. Dissertação (Mestrado em Ciências) - Centro de Energia Nuclear na Agricultura, Universidade de São Paulo, São Paulo, 2004.

LUCAS, F. H. R. et al. Diversidade de cianobactérias em um reservatório de abastecimento público do semiárido cearense. In: SEABRA, G. (Org.). CNEA - Congresso Nacional de Educação Ambiental; ENBio - Encontro Nordestino de Biogeografia. Anais... João Pessoa: Editora da UFPB, 2013.

MA, J. et al. Controlling cyanobacterial blooms by managing nutriente ratio and limitation in a large hyper-eutrophic lake: Lake Taihu, China. Journal of Environmental Sciences, p. 1-7, 2014a. 
MA, J. et al. Environmental factors controlling colony formation in blooms of the cyanobacteria Microcystis spp. in Lake Taihu, China. Harmful Algae, v. 31, p. 136-142, 2014b.

MACKINTOSH, C. et al. Cyanobacterial microcystin-LR is a potent and specific inhibitor of protein phosphatases 1 and 2A from both mammals and higher plants. FEBS Lett., v. 264, p. 187-192, 1990.

MAGALHÃES, V. F.; SOARES, R. M.; AZEVEDO, S. M. F. O. Microcystin contamination in fish from the Jacarepaguá Lagoon (Rio de Janeiro, Brazil): ecological implication and human health risk. Toxicon, v. 39, p. 1077-1085, 2001.

MANKIEWICZ, J. et al. Natural Toxins from Cyanobacterial. Acta Biologica Cracoviensia, v. 45, n. 2, p. 9-20, 2003.

MARZOUK, M. S. et al. Effect of freshwater toxic and non toxic cyanobacteria, (Microcystis aeruginosa) strains on some biochemical parameters of Oreochromis niloticus. Egypt, J.

Aquat. Biol. \& Fish., v. 17, n. 1, p. 55-68, 2013.

MATSUNAGA, S. et al. Anatoxin-a(s), a potent anticholinesterase from Anabaena flosaquae. Journal of American Chemical Society. 111. p. 8021-8023, 1989.

MATTHIENSEN, A.; YUNES, J. S.; CODD, G. A. Ocorrência, Distribuição e Toxicidade De Cianobactérias No Estuário Da Lagoa Dos Patos, RS. Rev. Brasil. Biol., v. 59, n. 3, p. 361376, 1999.

MAZMOUZ, R. et al. Biosynthesis of Cylindrospermopsin and 7-Epicylindrospermopsin in Oscillatoria sp. Strain PCC 6506: Identification of the cyr Gene Cluster and Toxin Analysis. Applied and Environmental Microbiology, v. 76, n. 15, p. 4943-4949, 2010.

MAZUR-MARZEC, H. et al. Diversity of Peptides Produced by Nodularia spumigena from Various Geographical Regions. Mar. Drugs, 11(1), p. 1-19, 2013.

MBEDI, S. et al. Variability of the microcystin synthetase gene cluster in the genus Planktothrix (Oscillatoriales, Cyanobacteria). FEMS Microbiology Letters, 245, p. 299-306, 2005.

MÉJEAN, A. et al. The Genome Sequence of the Cyanobacterium Oscillatoria sp. PCC 6506 Reveals Several Gene Clusters Responsible for the Biosynthesis of Toxins and Secondary Metabolites. Journal of Bacteriology, v. 192, n. 19, p. 5264-5265, 2010.

MÉJEAN, A.; PLOUX, O. A genomic view of secondary metabolite production in cyanobacteria. In: FRANCK, C.; CORINNE, C. C. (Eds.), Advances in Botanical Research, v. 65, Academic Press, p. 189-234, 2013.

MELCHER, S. S. Estudos morfológicos e moleculares de cianobactérias potencialmente tóxicas dos gêneros Cylindrospermopsis, Aphanizomenon e Raphidiopsis (Nostocales). 2008. 204 f. Tese (Doutorado em Biodiversidade Vegetal e Meio Ambiente) - Instituto de Botânica da Secretaria de Estado do Meio Ambiente, São Paulo, 2008.

MELLO, N. A. S. T.; MAIA-BARBOSA, P. M. Cyanobacteria bloom: selective filter for zooplankton? Braz. J. Biol., v. 75, n. 1, p. 165-174, 2015. 
METCALF, J. S. et al. A. Effects of physicochemical variables and cyanobacterial extracts on the immunoassay of microcystin-LR by two ELISA kits. Journal of Applied Microbiology, n. 89 , p. 532-538, 2000.

MICALLEF, M. L. et al. Exploring cyanobacterial genomes for natural product biosynthesis pathways. Marine Genomics, p. 1-12, 2014.

MICHALAK, A. M. et al. Record-setting algal bloom in Lake Erie caused by agricultural and meteorological trends consistent with expected future conditions. PNAS, v. 110, n. 16, p. 6448-6452, 2013.

MIHALI, T. K.; CHARMICHAEL, W. W.; NEILAN, B. A. A Putative Gene Cluster from a Lyngbya wollei Bloom that Encodes Paralytic Shellfish Toxin Biosynthesis. PLoS One, v. 6, n. 2, p. 1-9, 2011.

MISHRA, D. R.; MISHRA, S. Plume and bloom: effect of the Mississippi River diversion on the water quality of Lake Pontchartrain. Geocarto International, v. 25, n. 7, p. 555-568, 2010 .

MITROVIC, S. M.; BOWLING, L. C.; BUCKNEY, R. T. Vertical disentrainment of Anabaena circinalis in the turbid, freshwater Darling River, Australia: quantifying potential benefits from buoyancy. J. Plankton Res, v. 23, p. 47-55, 2001.

MOLICA, R. J. R. et al. O. Occurrence of saxitoxins and an anatoxin-a(s)-like anticholinesterase in a Brazilian drinking water supply. Harmful Algae, v. 4, p. 743-753, 2005.

MONTEIRO, F. M. et al. Ocorrência de Saxitoxinas em um Reservatório de Abastecimento Público no Estado da Paraíba. In: XII SIMPÓSIO DE RECURSOS HIDRÍCOS DO NORDESTE. Anais... Natal/RN, p. 1-10, 2014.

MOSER, M. C. Avaliação Ecotoxicológica do Manancial da Lagoa do Peri: testes genotóxicos, citotóxicos e mutagênicos. 2011. 125 p. Dissertação (Mestrado em Engenharia Ambiental) - Universidade Federal de Santa Catarina, Florianópolis, 2011.

MOSCHINI-CARLOS, V.; NISHIMURA, P. Y.; POMPÊO, M. A Importância e Problemática das Cianobactérias nos Reservatórios Eutrofizados. Revista SANEAS, Ano XII, n. 40, p. 14-18, 2011.

MOTA, H. R.; ROLLA, M. E. As cianobactérias e a qualidade da água: a importância de estar sempre atento. Companhia Energética de Minas Gerais, 8 p., 2011.

MÜLLER, C. C.; RAYA-RODRIGUEZ, M. T.; CYBIS, L. F. Diagnóstico da qualidade analítica na quantificação de cianobactérias. Eng Sanit Ambient., v. 15, n. 3, p. 283-290, 2010.

NEILAN, B. A. et al. Molecular identification of cyanobacteria associated with stromatolites from distinct geographical locations. Astrobiology, v. 2, p. 271-280, 2002.

NEILAN, B. A. et al. Nonribosomal peptide synthesis and toxigenicity of cyanobacteria. J. Bact., v. 181, p.4089-4097, 1999. 
NEILAN, B. A. et al. rRNA sequences and evolutionary relationships among toxic and nontoxic cyanobacteria of the genus Microcystis. Int J Syst Bacteriol, n. 47, p. 693-697, 1997.

NEILAN, B. A. et al. The genetics and genomics of cyanobacterial toxicity. Adv Exp Med Biol., v. 619, p. 417-452, 2008.

NEILAN, B. A. et al. Environmental conditions that influence toxin biosynthesis in cyanobacteria. Environmental Microbiology, v. 15, n. 5, p. 1239-1253, 2013.

NEILAN, B.A.; JACOBS, D.; GOODMAN, A. Genetic diversity and phylogeny of toxic cianobactéria determined by DNA polymorphisms within the phycocyanin locus. Appl. Environ. Microbiol. v. 61, n. 11, p. 3875-3883, 1995.

NEWCOMBE, G. et al. Cyanobacteria: Impacts of climate change on occurrence, toxicity and water quality management. Water Research, v. 46, p. 1347-1248, 2012.

NÜBEL, U. et al. PCR Primers To Amplify 16S rRNA Genes from Cyanobacteria. Applied and Environmental Microbiology, v. 63, n. 8, p. 3327-3332, 1997.

NYBOM, S. Biodegradation of Cyanobacterial Toxins. In: PETRE, M. (Ed.). Environmental Biotechnology: New Approaches and Prospective Applications, p. 147-170, 2013.

O'NEIL, J. M. et al. The rise of harmful cyanobacteria blooms: The potential roles of eutrophication and climate change. Harmful Algae, v. 14, p. 313-334, 2012.

OLIVER, R. L.; GANF, G. G. Freshwater blooms. In: WHITTON, B. A. and Potts, M. (Ed.). The Ecology of Cyanobacteria: Their Diversity in Time and Space. Netherlands: Kluwer Academic Publishers, p. 149-194, 2000.

OREN, A. Cyanobacteria: biology, ecology and evolution. In: SHARMA, N. K.; RAI, A. K. \& STAL, L. J. (Ed.). Cyanobacteria An Economic Perspective. Chichester: Wiley Blackwell, p. 3-19, 2014.

OSTERMAIER, V. et al. Genetic Variability of Microcystin Biosynthesis Genes in Planktothrix as Elucidated from Samples Preserved by Heat Desiccation during Three Decades. Plos One, v. 8, n. 11, p. 1-11, 2013.

PAABO, S.; IRWIN, D. M.; WILSON, A. C. DNA Damage Promotes Jumping between Templates during Enzymatic Amplification. The Journal of Biological Chemistry, v. 265, n. 8, p. 4718-4721, 1990.

PADOVESI-FONSECA, C.; PHILOMENO, M. G. Effects of algicide (copper sulfate) application on short-term fluctuations of phytoplankton in lake Paranoá, Central Brazil. Braz. J. Biol., v. 64, n. 4, p. 819-826, 2004.

PAERL, H. W.; HALL, N. S.; CALANDRINO, E. S. Controlling harmful cyanobacterial blooms in a world experiencing anthropogenic and climatic-induced change. Science of the Total Environment, 409, p. 1739-1745, 2011.

PAERL, H. W.; OTTEN, T. G. Harmful Cyanobacterial Blooms: Causes, Consequences and Controls. Microb. Ecol., p. 1-16, 2013. 
PAERL, H. W.; PAUL, V. J. Climate change: Links to global expansion of harmful cyanobacteria. Water Research, v. 46, p. 1349-1363, 2012.

PANOSSO, R. et al. Cianobactérias e cianotoxinas em reservatórios do Estado do Rio Grande do Norte e o potencial controle das florações pela tilápia do Nilo (Oreochromis niloticus).

Oecol. Bras., v. 11, n. 3, p. 433-449, 2007.

PARENTE, A. de A. Lago Paranoá: Lazer e Sustentabilidade Urbana. 2006. 149 f.

Dissertação (Mestrado em Arquitetura e Urbanismo) - Faculdade de Arquitetura e Urbanismo, Universidade de Brasília, Brasília, 2006.

PEARSON, L. A. et al. The genetics, biosynthesis and regulation of toxic specialized metabolites of cyanobacteria. Harmful Algae, v. 54, p. 98-111, 2016.

PEARSON, L. A.; NEILAN, B. A. The molecular genetics of cyanobacterial toxicity as a basis for monitoring water quality and public health risk. Current Opinion in Biotechnology, 19, p. 281-288, 2008.

PIMENTEL, J. da S. M. Quantificação de Cianobactérias Produtoras de Microcistina no Reservatório de Furnas (MG), através da PCR em Tempo Real , e sua Relação com Fatores Ambientais. 2009. 95 f. Dissertação (Mestrado em Biologia Vegetal). Programa de Pós-Graduação em Biologia Vegetal. Universidade Federal de Minas Gerais, Belo Horizonte, 2009.

PIMENTEL, J. S. M.; GIANI, A. Estimating toxic cyanobacteria in a Brazilian reservoir by quantitative real-time PCR, based on the microcystin synthetase D gene. J Appl Phycol, p. 1$10,2013$.

PIMENTEL, R. R.; NOGUEIRA, I. de S.; FARIA, M. T. Caracterização da Comunidade de Algas Fitoplanctônicas do Lago Vaca Brava Goiânia (GO). Revista Eletrônica de Educação da Faculdade Araguaia, v. 7, p. 311-324, 2015.

PINTO, M. T.; CAVALCANTI, C. G.; LUDUVICE, M. A evolução do processo de eutrofização do lago Paranoá - Brasília, após cinco anos de controle nas descargas de nutrientes. In: $20^{\circ}$ CONGRESSO BRASILEIRO DE ENGENHARIA SANITÁRIA E AMBIENTAL. Anais... Rio de Janeiro, p. 2325-2336, 1999.

POURIA, S. et al. Fatal microcystin intoxication in haemodialysis unit in Caruaru, Brazil. Lancet., v. 352, n. 9121, p. 21-6, 1998.

QIAN, S. S. et al. Quantifying and Reducing Uncertainty in Estimated Microcystin Concentrations from the ELISA Method. Environ Sci Technol. v.49, n. 24, p.14221- 14229, 2015.

QUIBLIER, C. et al. A review of current knowledge on toxic benthic freshwater cyanobacteria - Ecology, toxin production and risk management. Water Research, p. 1 - 16, 2013.

RANTALA, A. et al. Identification of hepatotoxin-producing cyanobacteria by DNA-chip. Environmental Microbiology, v. 10, n. 3, p. 653-664, 2008. 
RANTALA, A. et al. Anatoxin-a Synthetase Gene Cluster of the Cyanobacterium Anabaena sp. Strain 37 and Molecular Methods To Detect Potential Producers. Appl Environ Microbiol. n. 77, v. 20, p. 7271-7278, 2011.

REJMÁNKOVÁ, E. et al. Cyanobacterial blooms in Lake Atitlan, Guatemala. Limnologica, v. 41, p. 296-302, 2011.

RINTA-KANTO, J. M. et al. Quantification of toxic Microcystis spp. during the 2003 and 2004 blooms in western Lake Erie using quantitative real-time PCR. Environ. Sci. Technol., n. 39, v. 11, p. 4198-4205, 2005.

SÁ, L. L. C. et al. Ocorrência de uma floração de cianobactérias tóxicas na margem direita do Rio Tapajós, no Município de Santarém (Pará, Brasil). Rev Pan-Amaz Saude, v. 1, n. 1, p. 159-166, 2010.

SANCHES, S. M. et al. Presença da toxina microcistina em água, impactos na saúde pública e medidas de controle. Journal of Basic and Applied Pharmaceutical Sciences, v. 33, n. 2, p. 181-186, 2012.

SANT'ANNA, C. L. et al. Manual ilustrado de indentificação e contagem de cianobactérias planctônicas de águas continentais brasileiras. Rio de Janeiro: Interciência; São Paulo: Sociedade Brasileira de Ficologia - SBFic, p. 01-07, 2006.

SANT’ANNA, C. L. et al. Planktic Cyanobacteria from São Paulo State, Brazil: Chroococcales. Revista Brasil. Bot., v. 27, n. 2, p. 213-227, 2004.

SCHAKER, P. D. C. Análise genômica de isolados brasileiros de Cylindrospermopsis raciborskii com enfoque em cilindrospermopsina e fixação de $\mathbf{N}_{2} .2012 .139$ f. Dissertação (Mestrado em Ciências) - Escola Superior de Agricultura "Luiz de Queiroz", Universidade de São Paulo, Piracicaba, 2012.

SEIFERT, M. et al. First evidence for the production of cylindrospermopsin and deoxycylindrospermopsin by the freshwater benthic cyanobacterium, Lyngbya wollei (Farlow ex Gomont) Speziale and Dyck. Harmful Algae, 6, p. 73-80, 2007.

SEVILLA, E. et al. Microcystin-LR synthesis as response to nitrogen: transcriptional analysis of the mcyD gene in Microcystis aeruginosa PCC7806. Ecotoxicology, v. 19, p. 1167-1173, 2010 .

SILVA, C. S. P. da. Caracterização molecular de cianobactérias brasileiras e distribuição de genes de produtos naturais. 2006. 93f. Dissertação (Mestrado - Programa de PósGraduação em Ciências) - Centro de Energia Nuclear na Agricultura - Universidade de São Paulo, Piracicaba, 2006.

SILVA, C. P. et al. Detecção molecular e remoção de microcistinas nos processos de tratamento de água. SAÚDE REV., v. 12, n. 31, p. 61-68, 2012.

SILVA, S. C. F. da. Ecotoxicologia de cianobactérias no canal principal do Baixo Rio Tapajós, Santarém, Pará, Amazônia, Brasil. 2012. 93 f. Dissertação (Mestrado em Recursos Naturais da Amazônia). Programa de Pós-Graduação em Recursos Naturais da Amazônia, Universidade Federal do Oeste do Pará, Santarém/PA, 2012. 
SILVA, E. M. et al. Ocorrência de Cianobactérias no Reservatório de Mundaú, no Estado de Pernambuco, no Período de Janeiro de 2010 a Novembro de 2011. Vigilância Sanitária em Debate, v. 1, n. 3, p. 35-42, 2013.

SILVA, J. R. L. da et al. Fatores Condicionantes Ao Surgimento De Floração De Dolychospermum solitarium (Cyanobacteria, Nostocaceae) No Reservatório De Lajeado, Em Palmas-TO. In: XXI SIMPÓSIO BRASILEIRO DE RECURSOS HÍDRICOS. Anais.... Brasília/DF, p. 1-8, 2015.

SINHA, R. et al. Comparative genomics of Cylindrospermopsis raciborskii strains with differential toxicities. BMC Genomics, v. 15, n. 83, p. 1-14, 2014.

SIVONEN, K. et al. Isolation and Characterization of Hepatotoxic Microcystin Homologs from the Filamentous Freshwater Cyanobacterium Nostoc sp. Strain 152. Applied and Environmental Microbiology, v. 56, n. 9, p. 2650-2657, 1990.

SMITH, V. H.; SCHINDLER, D. W. Eutrophication science: where do we go from here? Trends in Ecology and Evolution, v. 24, n. 4, p. 201-207, 2009.

SOARES, R. M. et al. O. Sub-lethal exposure from microcystins to renal insufficiency patients in Rio de Janeiro-Brazil. Environ Toxicol, 2, p. 95-103, 2006.

SOARES, R. M.; MAGALHÃES, V. F.; AZEVEDO, S. M. F. O. Accumulation and depuration of microcystins (cyanobacteria hepatotoxins) in Tilapia rendalli (Cichlidae) under laboratory conditions. Aquatic Toxicology, 70, p. 1-10, 2004.

SOTERO-SANTOSA, R. B. et al. Toxicity of a cyanobacteria bloom in Barra Bonita Reservoir (Middle Tietê River, São Paulo, Brazil). Ecotoxicology and Environmental Safety, v. 64, p. 163-170, 2006.

SOUZA, A. P. de. Avaliação da Utilização de Índices de Integridade Biótica do Fitoplâncton como Ferramenta para Estimativa de Qualidade da Água nos Lagos Paranoá e Descoberto, no Distrito Federal. 2013. 174 f. Dissertação (Mestrado em Ciências) - Programa de Pós-Graduação em Tecnologia Ambiental e Recursos Hídricos, Departamento de Engenharia Civil e Ambiental, Faculdade de Tecnologia, Universidade de Brasília, Brasília, DF, 2013.

SRIVASTAVA, A. et al. Monitoring Approaches for a Toxic Cyanobacterial Bloom. Environmental Science \& Technology, v. 47, p. 8999-9013, 2013.

STARLING, J. E. M. de O. Avaliação de bioacumulação de microcistina-LR em tilápias do Nilo (Oreochromis niloticus) exploradas comercialmente no lago Paranoá (BrasíliaDF). 2010. 107 f. Dissertação (Mestrado em Biologia Animal) - Programa de Pós-Graduação em Biologia Animal. Instituto de Ciências Biológicas, Universidade de Brasília, Brasília, DF, 2010 .

STRAUB, C. et al. A Day in the Life of Microcystis aeruginosa Strain PCC 7806 as Revealed by a Transcriptomic Analysis. Plos One. v. 6, n. 1, p. 1-12, 2011.

SVERCEL, M. Negative Allelopathy Among Cyanobacteria. In: FERRÃO-FILHO, A. da S. (ed.). Cyanobacteria: Ecology, Toxicology and Management. Nova Science Publishers, New York, 2013. 
TEIXEIRA, M. da G. L. C. et al. Gastroenteritis epidemicin the area of Itaparica, Bahia, Brazil. Bulletin of PAHO, n. 27, v. 3, p. 244-253, 1993.

TILLETT, D. et al. Structural organization of microcystin biosynthesis in Microcystis aeruginosa PCC7806: an integrated peptide-polyketide synthetase system. Chemistry \& Biology, v. 7, n. 10, p. 753-764, 2000.

TISDALE, E. S. Epidemic of intestinal disorders in Charleston, W. Va., occurring simultaneously with unprecedented water supply conditions. American Journal of Public Health, v. 21, p. 198-200, 1931.

TORQUATO, K. C. Ocorrências de cianobactérias em reservatórios de bacias hidrográficas do Estado da Paraíba. 2012. 61 f. Dissertação (Mestrado em Ciência e Tecnologia Ambiental), Centro de Ciências e Tecnologias, Universidade Estadual da Paraíba, 2012.

TÓTH, T. N. et al. Carotenoids are essential for the assembly of cyanobacterial photosynthetic complexes. Biochimica et Biophysica Acta, p. 1-13, 2015.

TUNDISI, J. G. et al. A bloom of cyanobacteria (Cylindrospermopsis raciborskii) in UHE Carlos Botelho (Lobo/Broa) reservoir: a consequence of global change? Braz. J. Biol., v. 75, n. 2, p. 507-508, 2015.

TURNER, P. C. et al. Pneumonia associated with cyanobacteria. British Medical Journal, n. 300, p. 1440-1441, 1990.

TWISS, M. R.; GOUVEA, S. P. Why do Cyanobacteria Produce Toxins? Investigating a Possible Trigger for Microcystin Production in a Harmful Algal Bloom. In: CONNERTON, M.; CRYSLER, C. (Eds.). Monitoring Harmful Algal Blooms. Great Lakes Research Review, v. 7, p. 30-32, 2006.

UFELMANN, H. et al. Human and rat hepatocyte toxicity and protein phosphatase 1 and $2 \mathrm{~A}$ inhibitory activity of naturally occurring desmethyl-microcystins and nodularins. Toxicology, v. 293, p. 59- 67, 2012.

VALÉRIO, E.; CHAVES, S.; TENREIRO, R. Diversity and Impact of Prokaryotic Toxins on Aquatic Environments: A Review. Toxins, 2, p. 2359-2410, 2010.

VIEIRA, J. M. dos S. et al. Toxic cyanobacteria and microcystin concentrations in a public water supply reservoir in the Brazilian Amazonia region. Toxicon, 45, p. 901-909, 2005.

von SPERLING, E.; FERREIRA, A. C. da S.; GOMES, L. N. L. Comparative eutrophication development in two Brazilia water supply reservoirs with respect to nutrient concentrations and bacteria growth. Desalination, n. 226, p. 169-174, 2008.

WANG, Z. et al. An integrated method for removal of harmful cyanobacterial blooms in eutrophic lakes. Environmental Pollution, v. 160, p. 34-41, 2012.

WATSON, S. B. et al. Harmful Algal Blooms. In: WEHR, J. D.; SHEATH, R. G.; KOCIOLEK, J. P. (Eds.). Freshwater Algae of North America, Second Edition, Elsevier Inc., p. 873-920, 2015. 
WEISBURG, W. G. et al. 16S Ribosomal DNA Amplification for Phylogenetic Study. Journal of Bacteriology, v. 173, n. 2, p. 697-703, 1991.

WELKER, M.; von DÖHREN, H. Cyanobacterial peptides - Nature's own combinatorial biosynthesis. FEMS Microbial. Rev., v. 30, p. 530-563, 2006.

WHITTON, B. A.; POTTS, M. The Ecology of Cyanobacteria: Their Diversity in Time and Space. Kluwer Academic Publishers, Dordrecht, Netherlands, p. 01-11, 2000.

WHO. Guidelines for Drinking-water Quality. Second edition, Addendum to Volume 2, Health Criteria and Other Supporting Information. World Health Organization, Geneva, 1998.

WHO. Guidelines for Drinking-water Quality. Third edition, Addendum to Volume 2, Health Criteria and Other Supporting Information. World Health Organization, v. 1, Geneva, 2008 .

WIESE, M. et al. Neurotoxic Alkaloids: Saxitoxin and Its Analogs. Mar Drugs, v. 8, n. 7, p. 2185-2211, 2010.

WINTZINGERODE, F. V.; GÖBEL, U. B.; STACKEBRANDT, E. Determination of Microbial Diversity in Environmental Samples: Pitfalls of PCR-Based rRNA Analysis. FEMS Microbiology Reviews, v. 21, p. 213-229, 1997.

WU, X. et al. Cyanobacteria blooms produce teratogenic retinoic acids. PNAS, v. 109, n. 24, p. 9477-9482, 2012.

WU, Y. et al. Seasonal dynamics of water bloom-forming Microcystis morphospecies and the associated extracellular microcystin concentrations in large, shallow, eutrophic Dianchi Lake. Journal of Environmental Sciences, v. 26, p. 1921-1929, 2014.

WYNN-WILLIAMS, D. D. Cyanobacteria in Deserts - Life at the Limit? In: WHITTON, B. A. and POTTS, M. (Eds.). The Ecology of Cyanobacteria: Their Diversity in Time and Space. Netherlands: Kluwer Academic Publishers, p. 341-366, 2000.

ZEGURA, B.; STRASER, A.; FILIPIC, M. Genotoxicity and potential carcinogenicity of cyanobacterial toxins - a review. Mutation Research, v. 727, p. 16-41, 2011. 


\section{APÊNDICE A - IMAGENS DOS GÉIS DE AGAROSE (16S DNAr)}

Imagens dos géis de agarose resultantes dos ensaios de PCR utilizando os oligonucleotídeos da porção do gene 16S DNAr, com amostras coletas no lago Paranoá no período de 2012 a 2014, em diferentes estações denominadas: A, B, C, D, E, G, H.

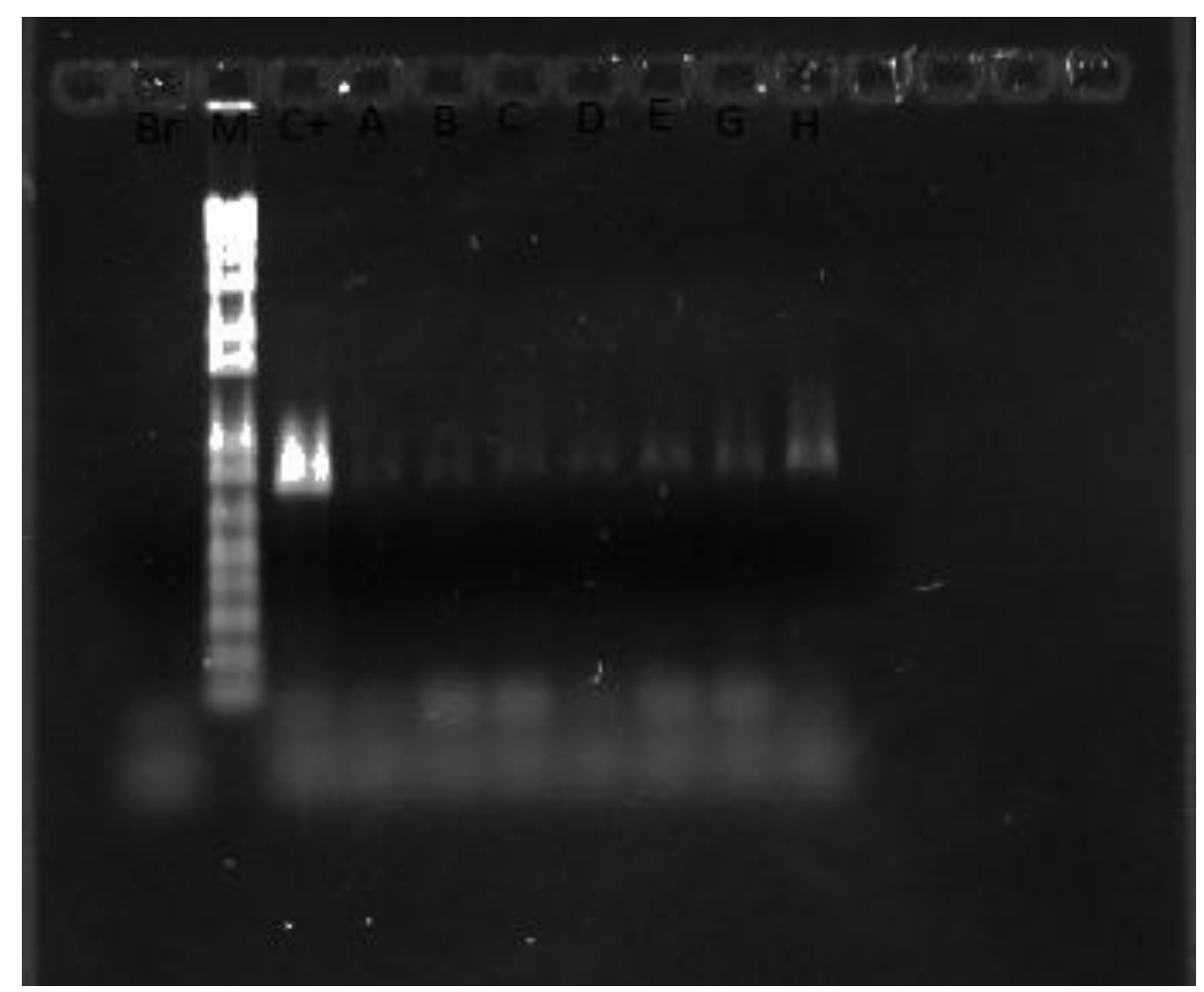

Gel de agarose $1 \%$ com os produtos de PCR do $16 \mathrm{~S}$ DNAr. $\mathrm{Br}$ - branco; $\mathrm{M}$ - marcador; $\mathrm{C}+$ controle; A, B, C, D, E, G, H -amostras de agosto de 2012. 


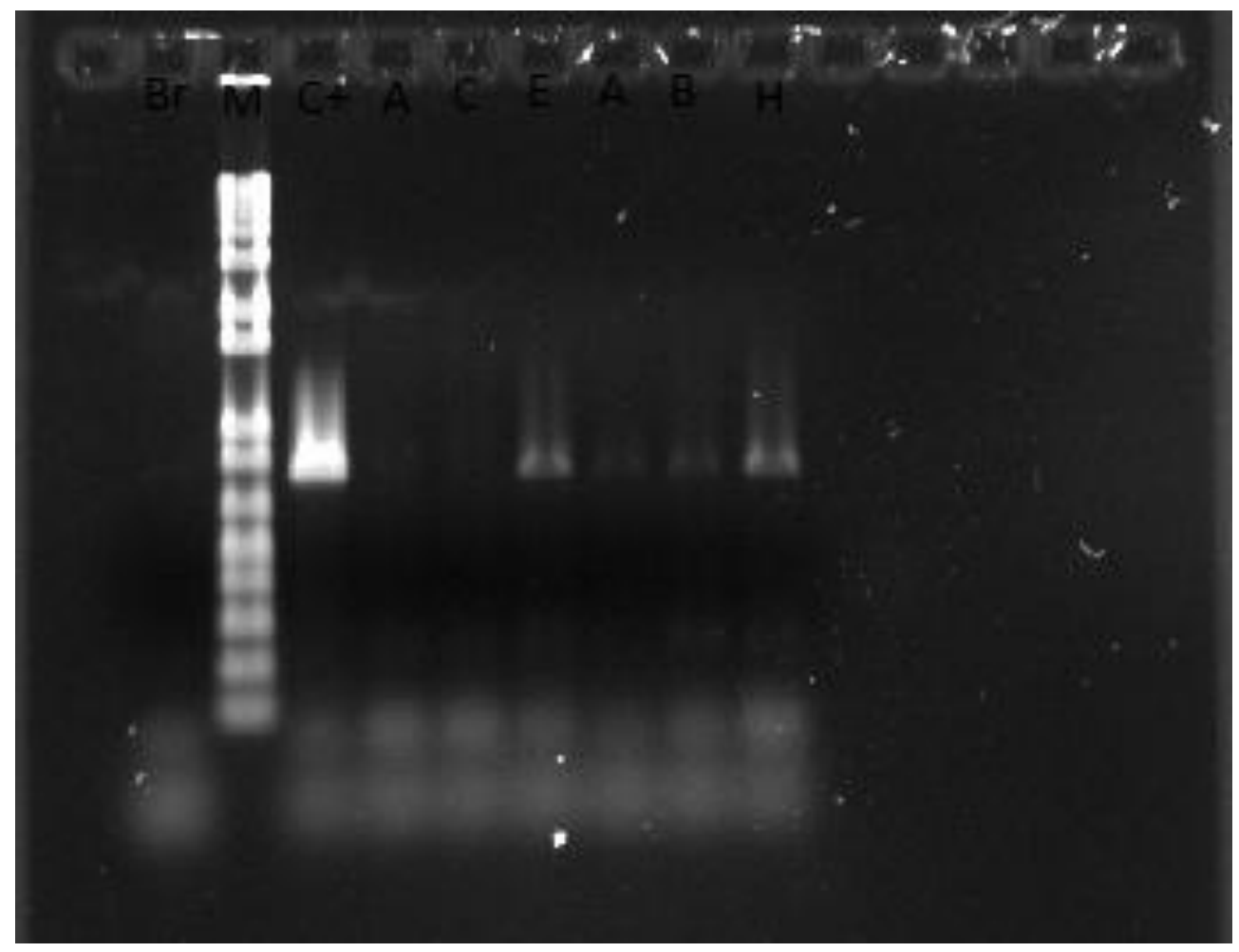

Gel de agarose $1 \%$ com os produtos de PCR do $16 \mathrm{~S}$ DNAr. $\mathrm{Br}$ - branco; $\mathrm{M}$ - marcador; $\mathrm{C}+$ controle; A, C, E - amostras de novembro de 2012; A, B, H - amostras de dezembro de 2012. 


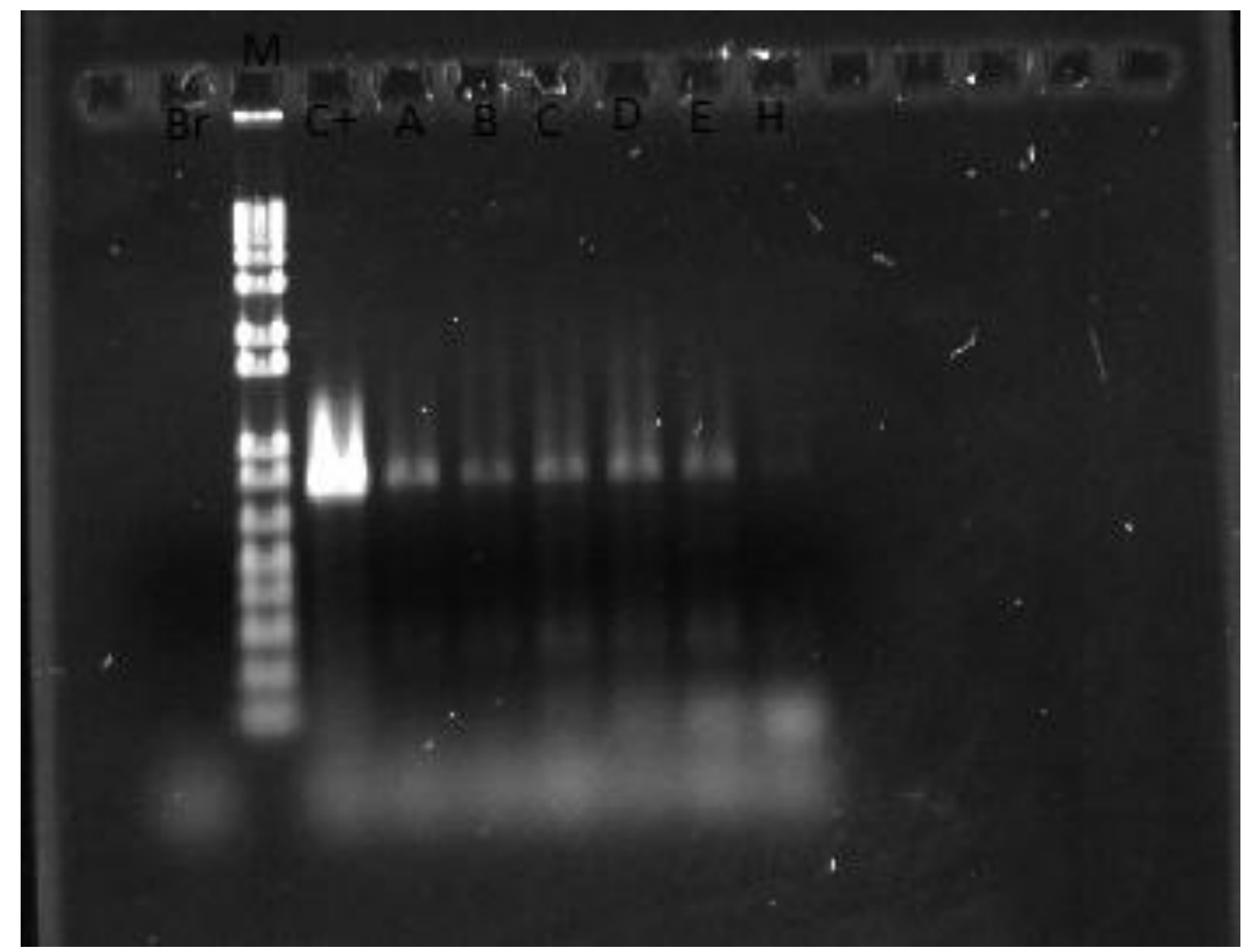

Gel de agarose $1 \%$ com os produtos de PCR do $16 \mathrm{~S}$ DNAr. $\mathrm{Br}$ - branco; $\mathrm{M}$ - marcador; C+ - controle; A, B, C, D, E, H - amostras de janeiro de 2013. 


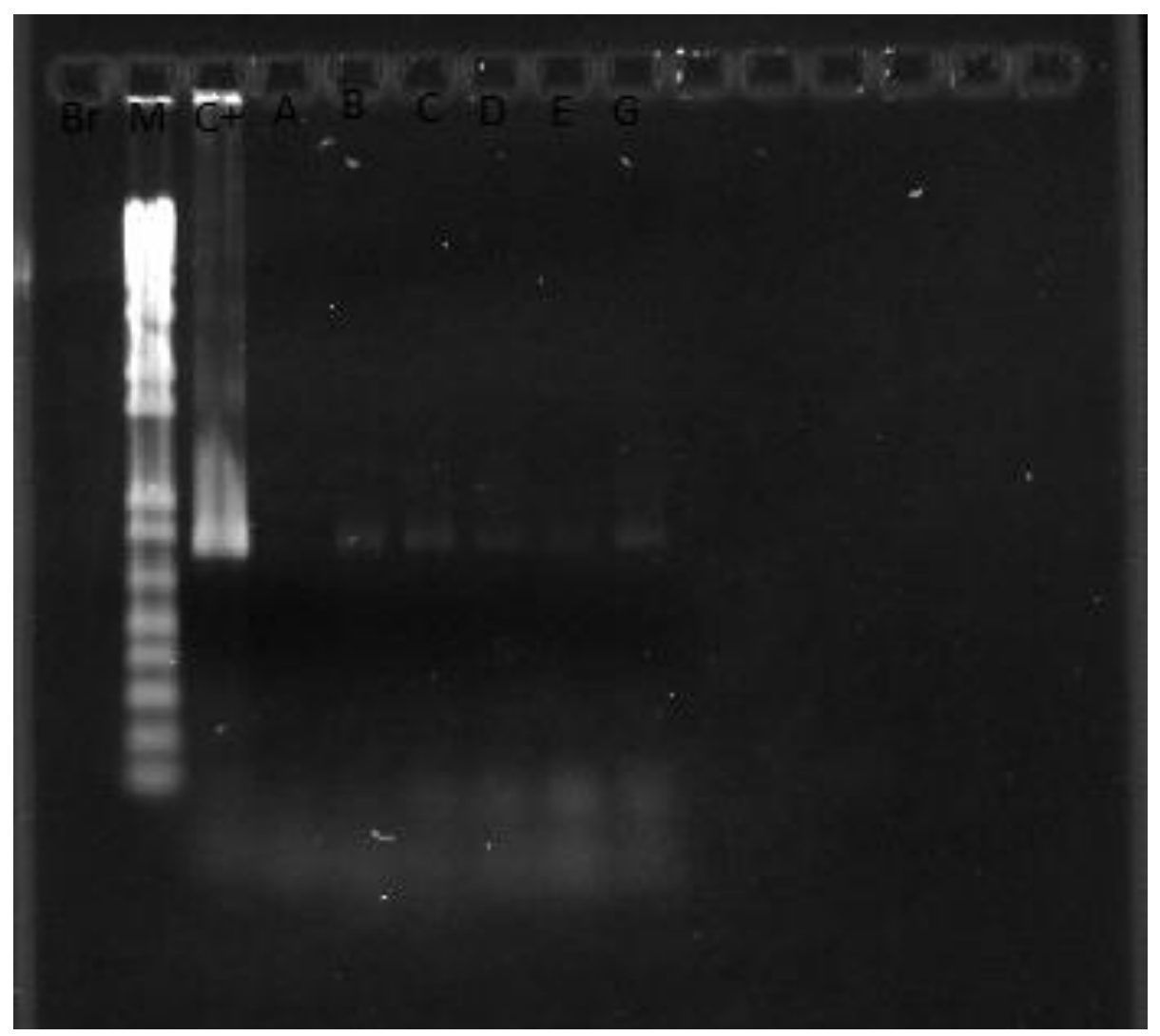

Gel de agarose $1 \%$ com os produtos de PCR do $16 \mathrm{~S}$ DNAr. $\mathrm{Br}$ - branco; $\mathrm{M}$ marcador; C+ - controle; A, B, C, D, E, G - amostras de junho de 2013. 


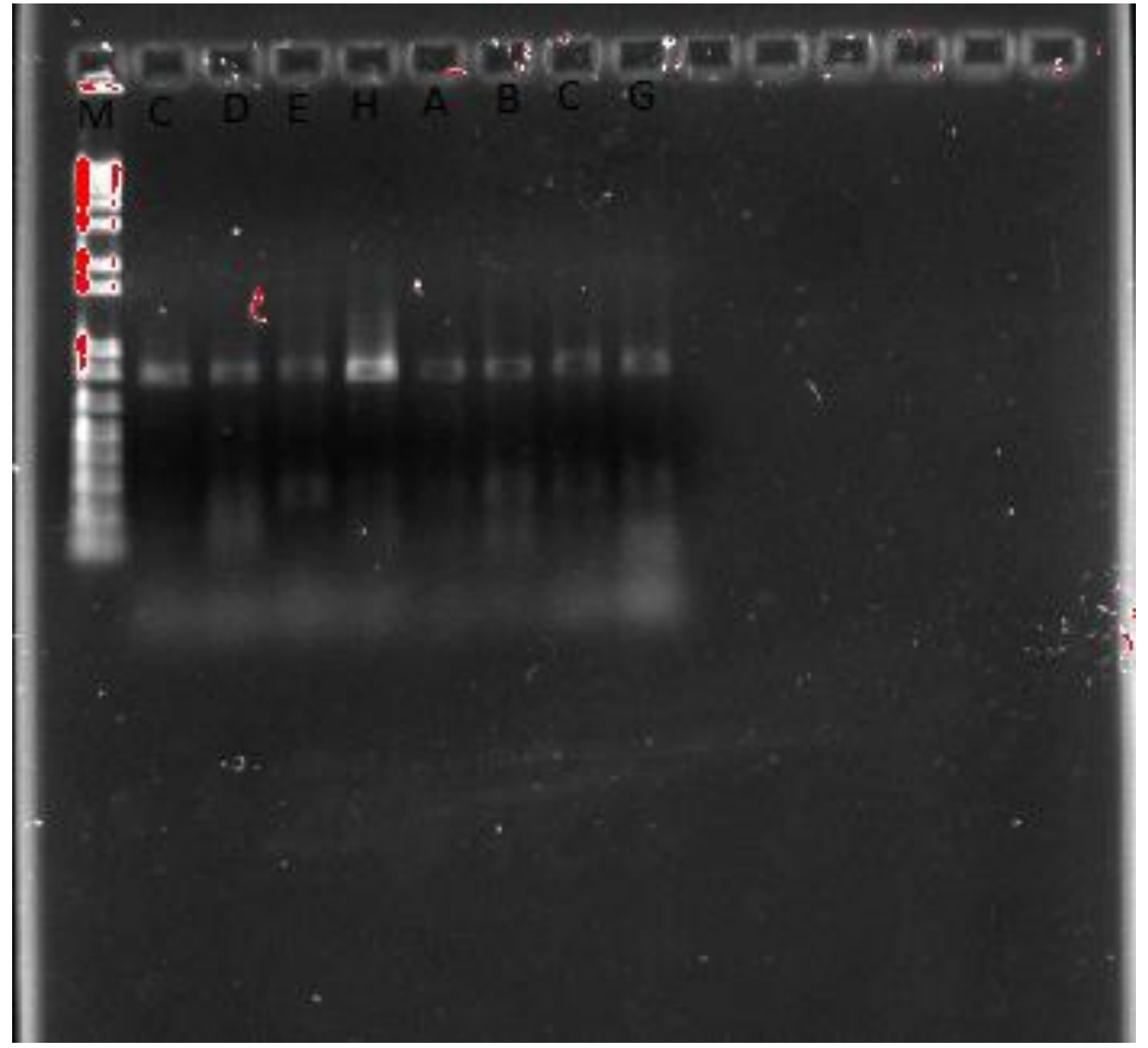

Gel de agarose $1 \%$ com os produtos de PCR do 16 S DNAr. M - marcador; C, D, E, $\mathrm{H}$ - amostras de janeiro de 2014; A, B, C, G - março de 2014. 


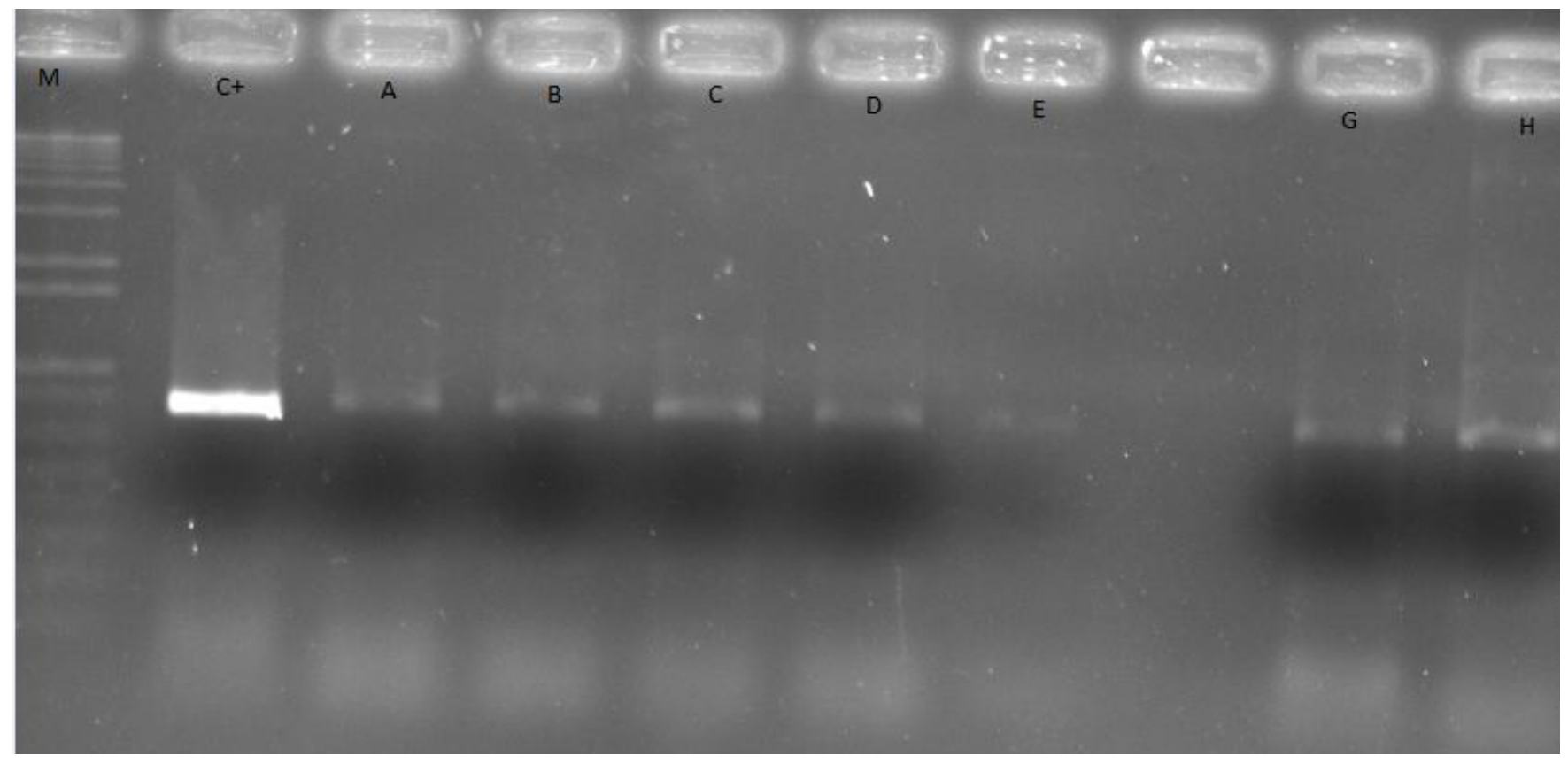

Gel de agarose $1 \%$ com os produtos de PCR do 16 S DNAr. M - marcador; C+ - controle; A, B, C, D, E - julho de 2014; - branco; G, H - amostras de julho de 2014. 


\section{APÊNDICE B - IMAGENS DOS GÉIS DE AGAROSE (FICOCIANINA)}

Imagens dos géis de agarose resultantes dos ensaios de PCR utilizando os oligonucleotídeos das porções $c p c \mathrm{~A}$ e $c p c \mathrm{~B}$, incluindo o espaço intergênico (cpcBA-IGS), do operon da ficocianina, com amostras coletas no lago Paranoá no período de 2012 a 2014, em diferentes estações denominadas: A, B, C, D, E, G, H.

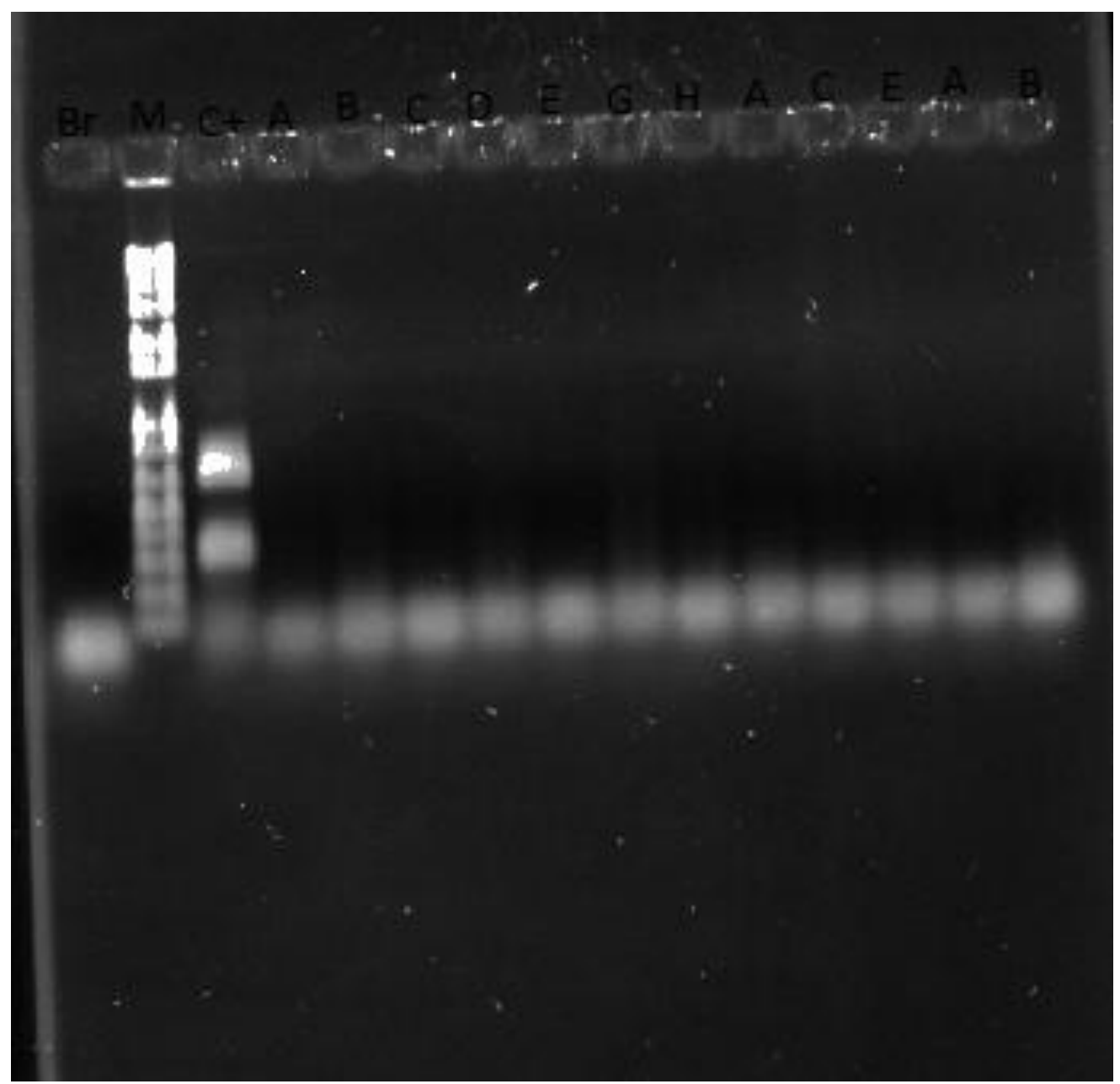

Gel de agarose $1 \%$ com os produtos de PCR do gene da ficocianina (cpcBA-IGS). Br branco; M - marcador; A-H (08/2012); A, C, E (11/2012); A, B (12/2012). 
Br M C $+C D E H C D$

Gel de agarose $1 \%$ com os produtos de PCR do gene da ficocianina (cpcBA-IGS). Br branco; M - marcador; C+ - controle; C, D, E, H (01/2013); C, D, E, H (01/2014). 


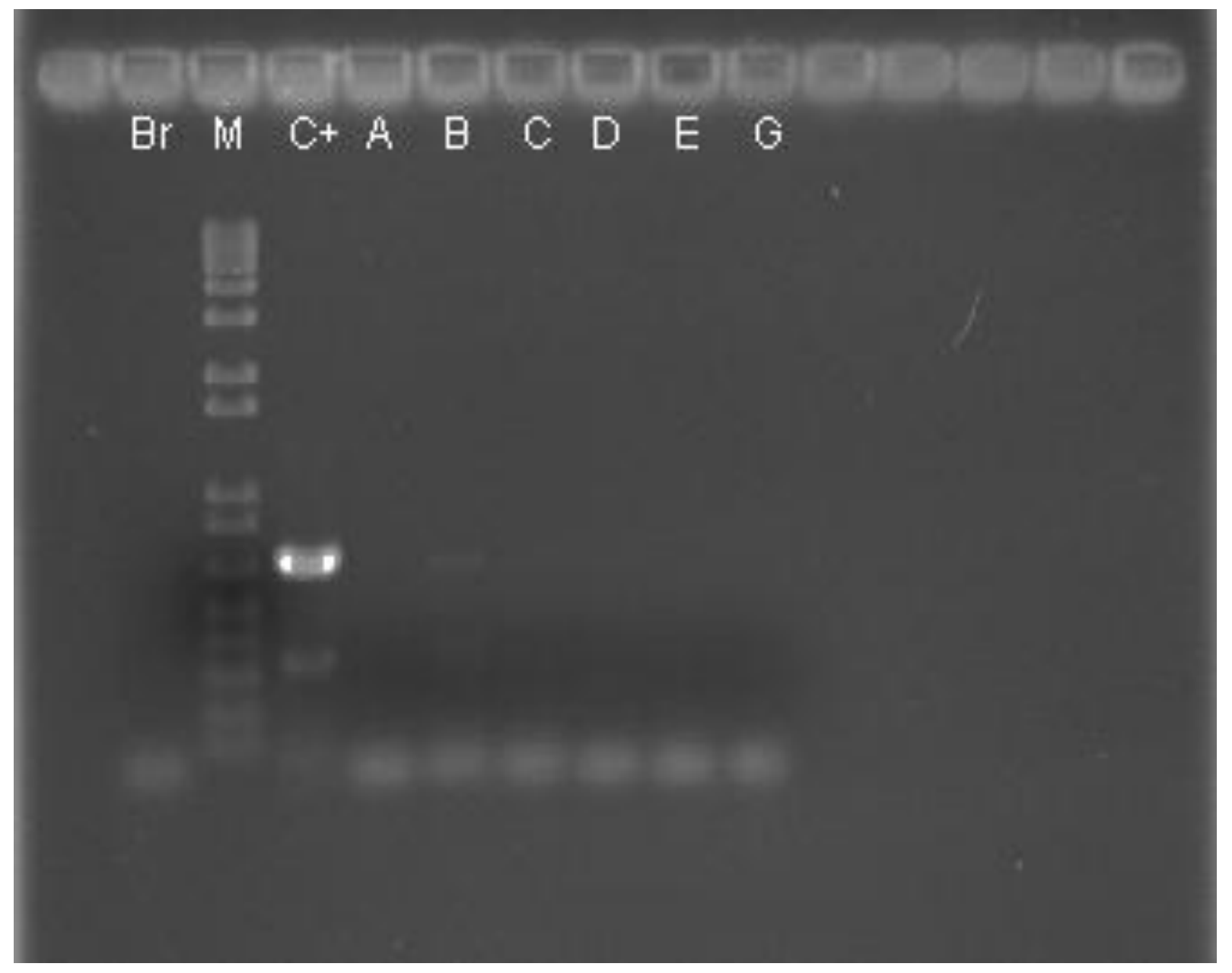

Gel de agarose $1 \%$ com os produtos de PCR do gene da ficocianina (cpcBA-IGS). Br branco; M - marcador; C+ - controle; A-G (06/2013). 


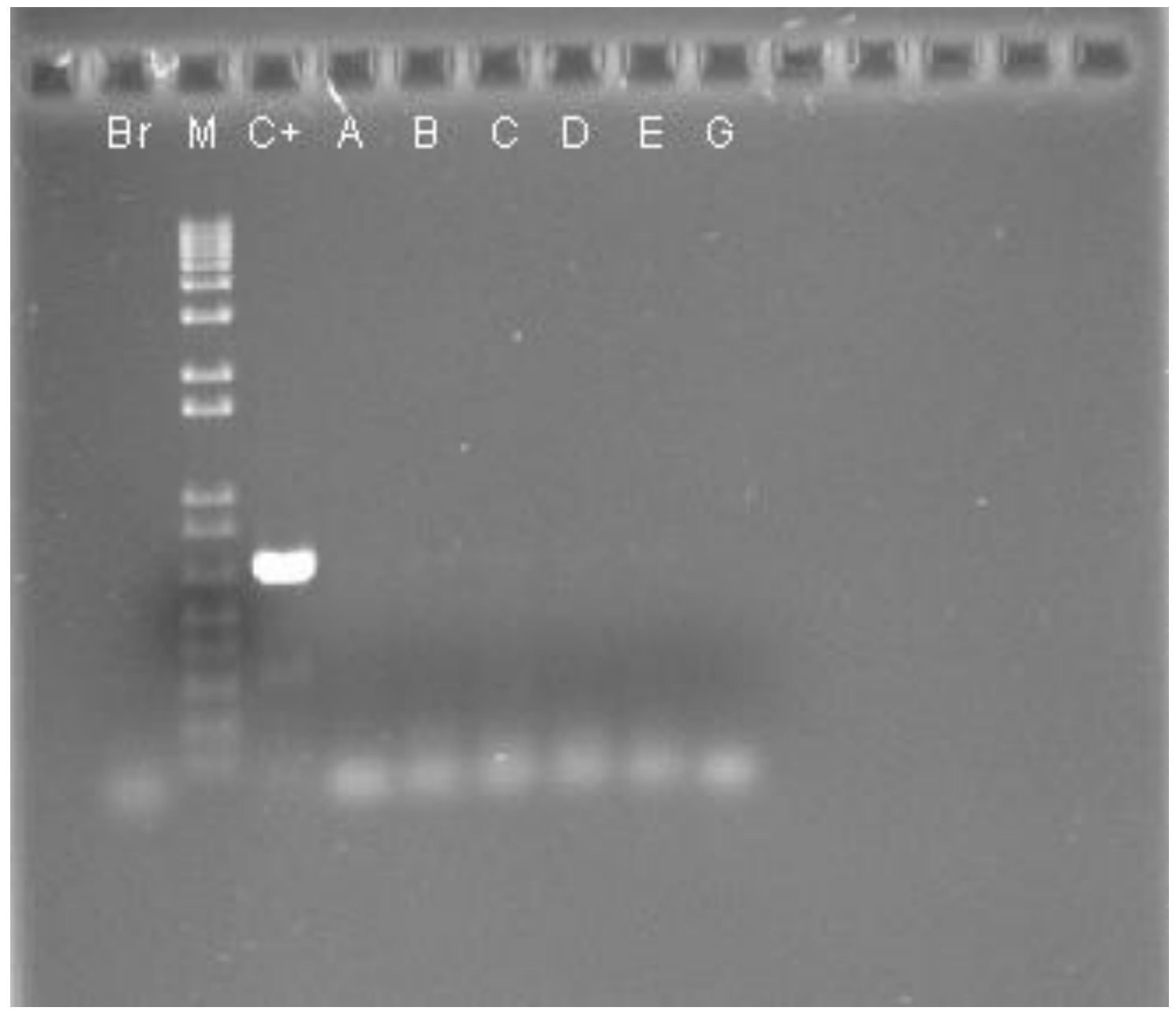

Gel de agarose $1 \%$ com os produtos de PCR do gene da ficocianina (cpcBA-IGS). $\mathrm{Br}-$ branco; M - marcador; C+ - controle; A-G (07/2014). 


\section{APÊNDICE C - IMAGENS DOS GÉIS DE AGAROSE (mcyB E mcyD)}

Imagens dos géis de agarose resultantes dos ensaios de PCR utilizando os iniciadores das porções dos genes $m c y \mathrm{~B}$ e $m c y \mathrm{D}$, com amostras coletas no lago Paranoá no período de 2012 a 2014, em diferentes estações denominadas: A, B, C, D, E, G, H.

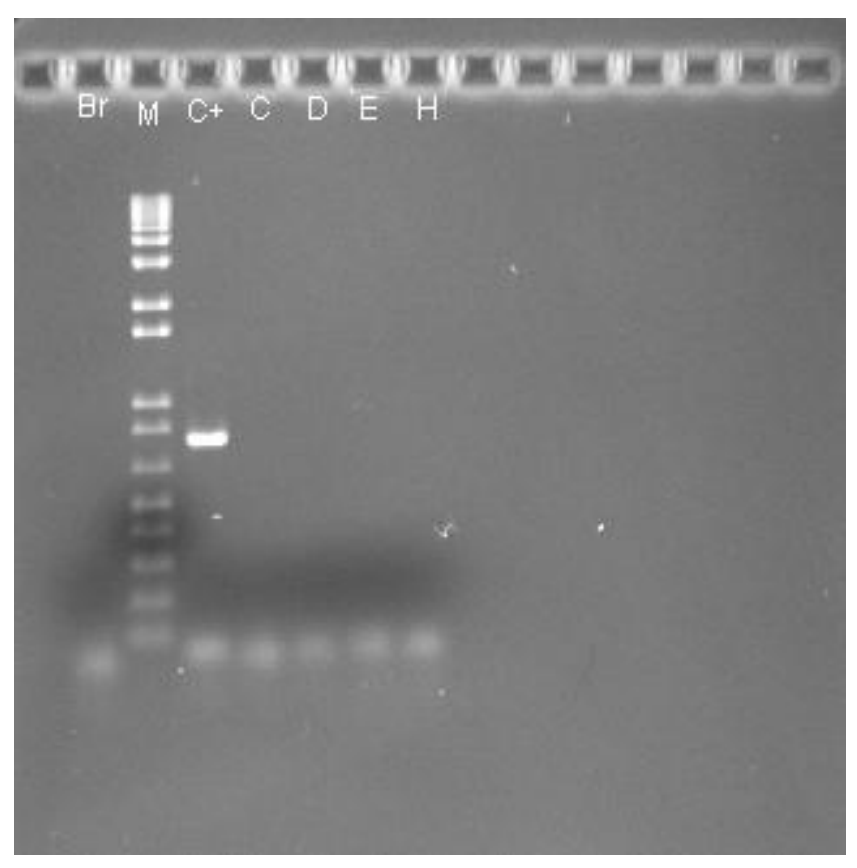

Gel de agarose $1 \%$ com os produtos de PCR do gene de biossíntese de microcistina mcyB. Br - branco; M - marcador; C+ - controle; C, D, E, H - janeiro de 2013. 


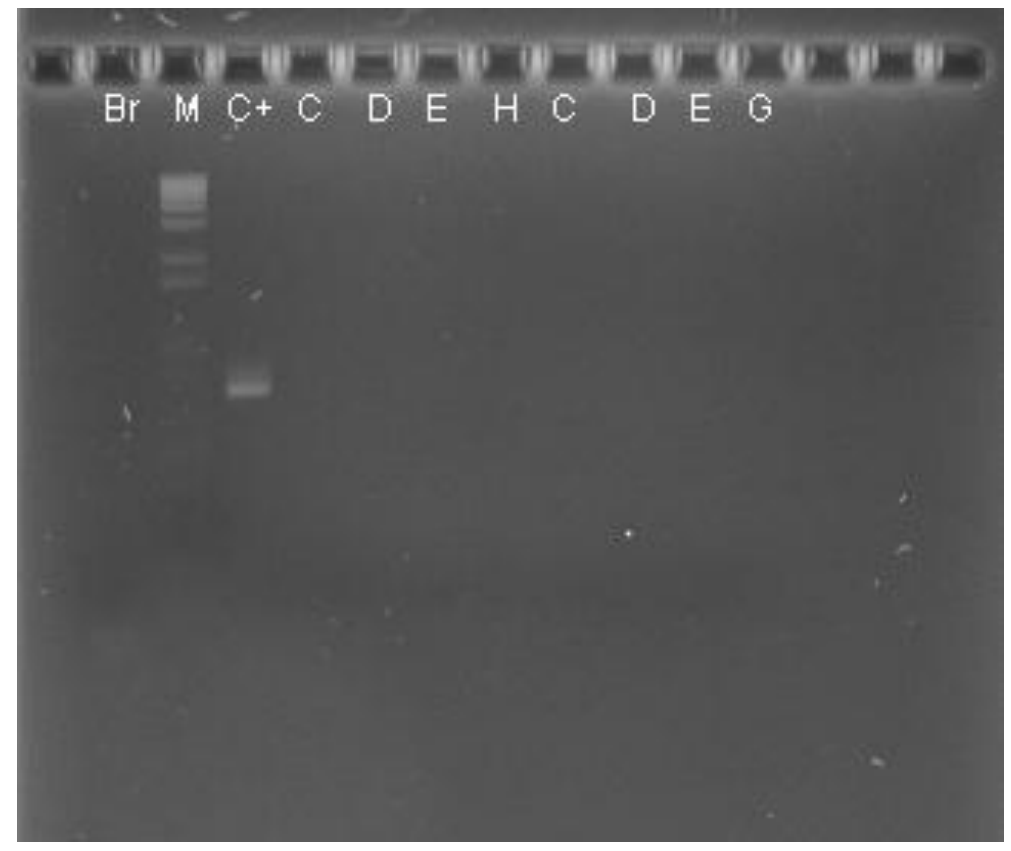

Gel de agarose $1 \%$ com os produtos de PCR do gene de biossíntese de microcistina - mcyB. $\mathrm{Br}$ - branco; M - marcador; C+ - controle; C, D, E - H - janeiro de 2014; C, D, E, G - junho de 2013. 


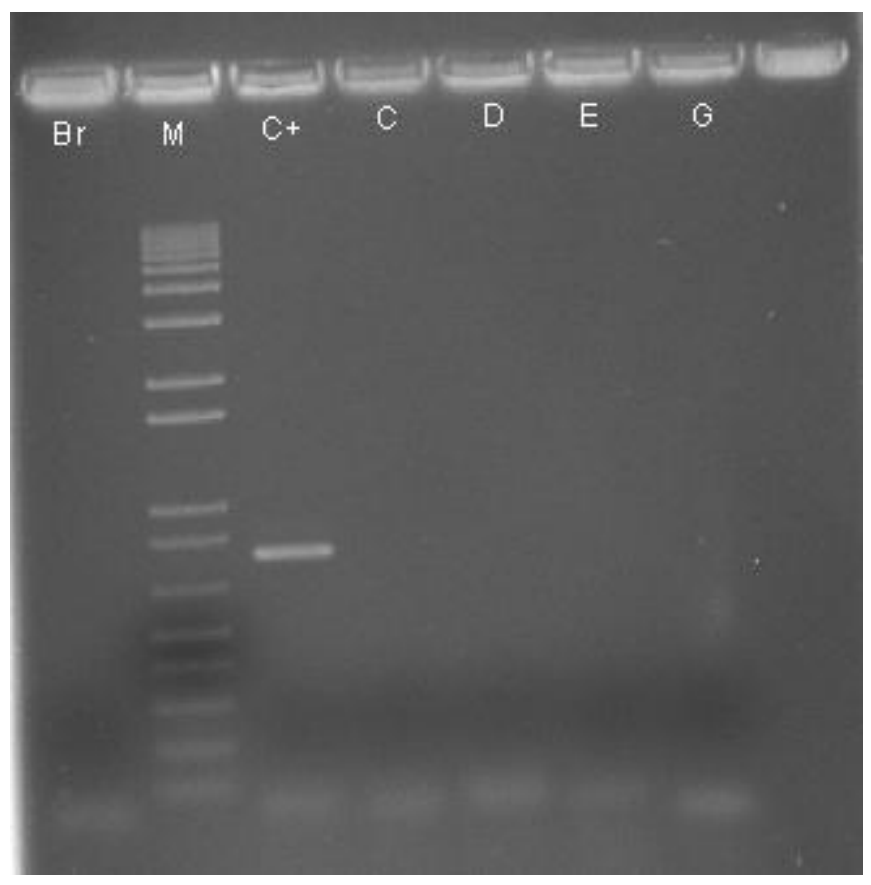

Gel de agarose $1 \%$ com os produtos de PCR do gene de biossíntese de microcistina - mcyB. $\mathrm{Br}$ - branco; M - marcador; C+ - controle; C, D, E - G - julho de 2014. 


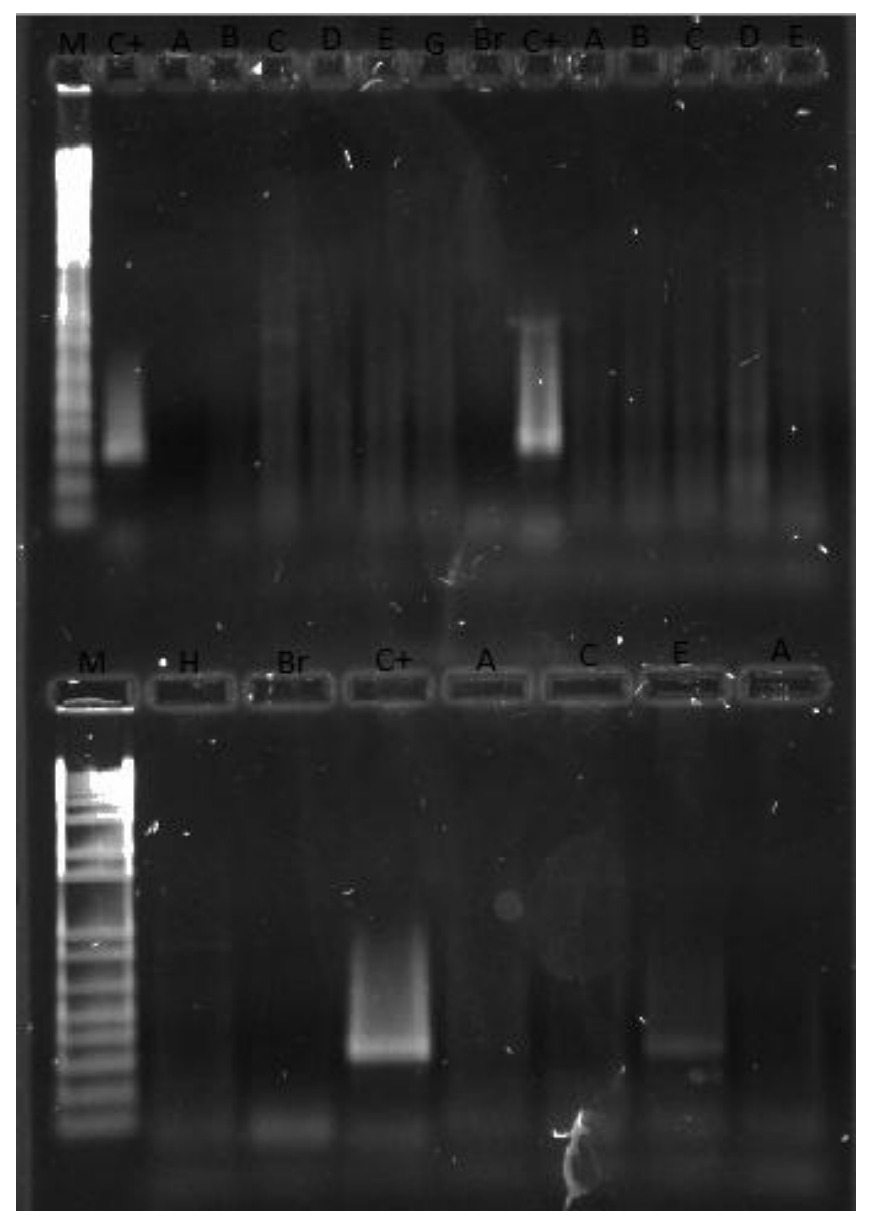

Gel de agarose $1 \%$ com os produtos de PCR do gene de biossíntese de microcistina - mcyD. Parte superior do gel: M - marcador; C+ - controle; A, B, C, D, E, G - junho de 2013; Br branco; A, B, C, D, E - janeiro de 2013. Parte inferior do gel: H - janeiro de 2013; A, C, E novembro de 2012; A - dezembro de 2012. 


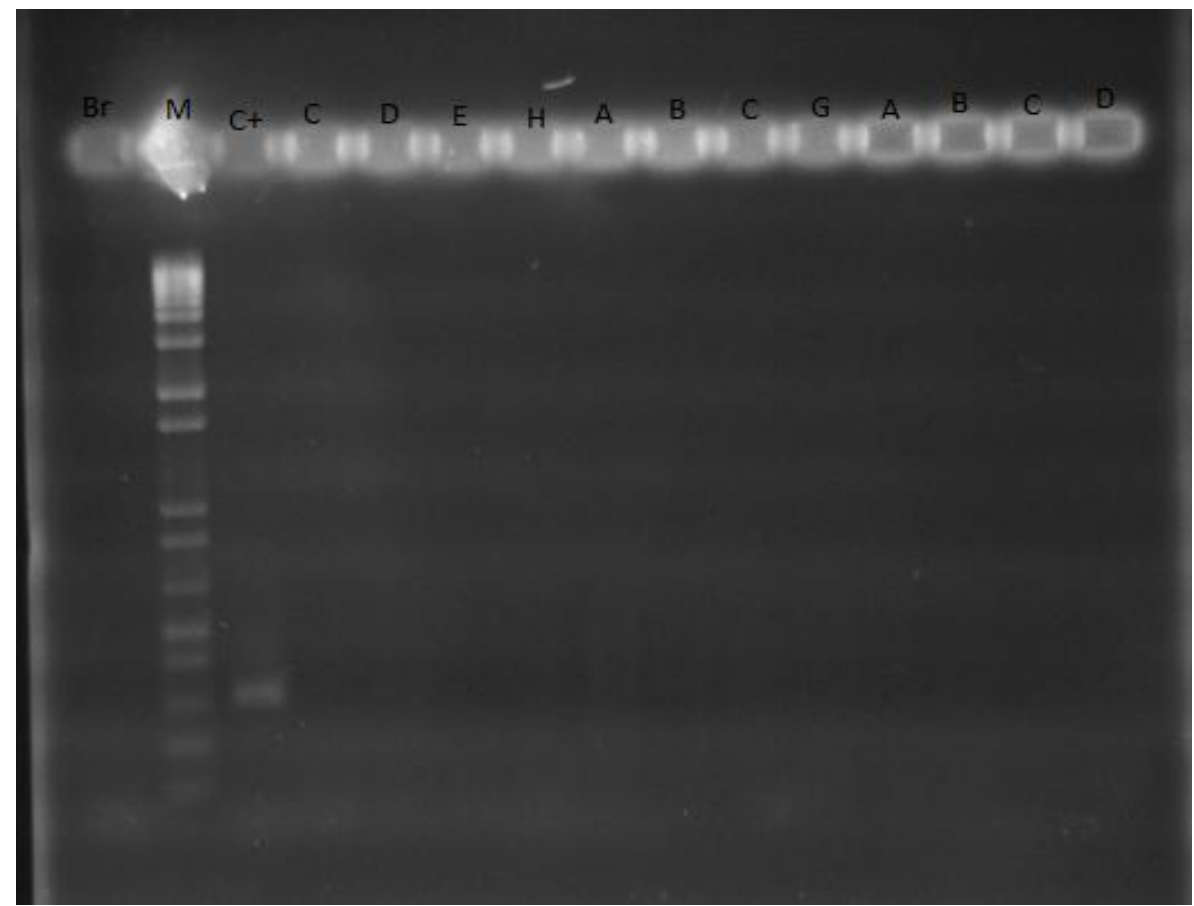

Gel de agarose $1 \%$ com os produtos de PCR do gene de biossíntese de microcistina - mcyD. $\mathrm{Br}$ - branco; M - marcador; C+ - controle; C, D, E, H - janeiro de 2014; A, B, C, G - março de 2014; A, B, C, D - julho de 2014. 